UNIVERSIDADE DE BRASÍLIA

FACULDADE DE AGRONOMIA E MEDICINA VETERINÁRIA

PROGRAMA DE PÓS-GRADUAÇÃO EM AGRONOMIA

CARACTERES MORFO-AGRONÔMICOS E BIOQUÍMICOS DE CLONES ELITE DE MANDIOCA DE MESA COM RAÍZES DE POLPAS AMARELADA E ROSADA

ELISIANE FUHRMANN

TESE DE DOUTORADO

EM AGRONOMIA

BRASÍLIA/DF

SETEMBRO/2015 


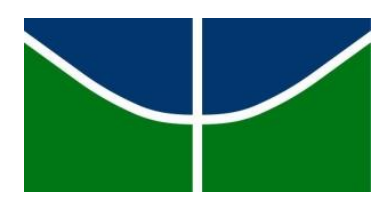

UNIVERSIDADE DE BRASÍLIA

FACULDADE DE AGRONOMIA E MEDICINA VETERINÁRIA PROGRAMA DE PÓS-GRADUAÇÃO EM AGRONOMIA

CARACTERES MORFO-AGRONÔMICOS E BIOQUÍMICOS DE CLONES ELITE DE MANDIOCA DE MESA COM RAÍZES DE POLPAS AMARELADA E ROSADA

ELISIANE FUHRMANN

\author{
ORIENTADOR: FÁBIO GELAPE FALEIRO \\ CO-ORENTADOR: EDUARDO ALANO VIEIRA
}

TESE DE DOUTORADO

EM AGRONOMIA

PUBLICAÇÃO: 034D/2015

BRASÍLIA/DF

SETEMBRO/2015 


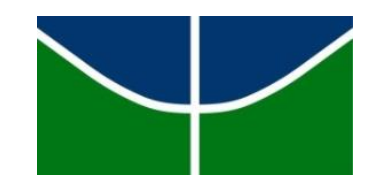

UNIVERSIDADE DE BRASÍLIA

FACULDADE DE AGRONOMIA E MEDICINA VETERINÁRIA PROGRAMA DE PÓS-GRADUAÇÃO EM AGRONOMIA

\title{
CARACTERES MORFO-AGRONÔMICOS E BIOQUÍMICOS DE CLONES ELITE DE MANDIOCA DE MESA COM RAÍZES DE
} POLPAS AMARELADA E ROSADA

\author{
ELISIANE FUHRMANN
}

TESE DE DOUTORADO SUBMETIDA AO PROGRAMA DE PÓSGRADUAÇÃO EM AGRONOMIA, COMO PARTE DOS REQUISITOS NECESSÁRIOS À OBTENÇÃO DO GRAU DE MESTRE/DOUTOR EM AGRONOMIA.

APROVADA POR:

Fábio Gelape Faleiro, D.Sc., Embrapa Cerrados, CPF: 739.634.706-82, fabio.faleiro@embrapa.br (Orientador)

Marcelo Fagioli, D.Sc., Universidade de Brasília, CPF: 729.409.306-78, mfagioli@unb.br (Examinador interno)

Nilton Tadeu Vilela Junqueira, Embrapa Cerrados, CPF: 309.620.646-53, nilton.junqueira@embrapa.br (Examinador interno)

Luiz Joaquim Castelo Branco Carvalho, Embrapa Recursos Genéticos e Biotecnologia, CPF: 116.435.956-87, luiz.castelo@embrapa.br (Examinador externo)

Léo Duc Haa Carson Schwartzhaupt da Conceição, Embrapa Cerrados, CPF: 737.004.440-87, leo.carson@embrapa.br 


\section{FICHA CATALOGRÁFICA}

Fuhrmann, Elisiane

Caracteres morfo-agronômicos e bioquímicos de clones elite de

mandioca de mesa com raízes de polpas amarelada e rosada. I

Elisiane Fuhrmann; orientação de Fábio Gelape

Faleiro. - Brasília, 2015.

$111 \mathrm{f}$ : : il.

Tese de Doutorado (D) - Universidade de Brasília/Faculdade de Agronomia e Medicina Veterinária, 2015.

1. Manihot esculenta Crantz. 2. Melhoramento Genético.

3. Caracteres morfológicos. 4. Caracteres agronômicos.

5. Caracteres bioquímicos. 6. Biofortificação

I. Faleiro, F. G. II. Doutor.

\section{REFERÊNCIA BIBLIOGRÁFICA}

FUHRMANN, E. Caracteres morfo-agronômicos e bioquímicos de clones elite de mandioca de mesa com raízes de polpas amarelada e rosada. Brasília: Faculdade de Agronomia e Medicina Veterinária, Universidade de Brasília, 2015, 111f. Tese de Doutorado.

\section{CESSÃO DE DIREITOS}

\section{NOME DO AUTOR: ELISIANE FUHRMANN}

TÍTULO DA TESE: Caracteres morfo-agronômicos e bioquímicos de clones elite de mandioca de mesa com raízes de polpas amarelada e rosada.

GRAU: Doutor

ANO: 2015

É concedida à Universidade de Brasília de Brasília permissão para reproduzir cópias desta tese de doutorado para única e exclusivamente propósitos acadêmicos e científicos. O autor reserva para si os outros direitos autorais, de publicação. Nenhuma parte desta tese de doutorado pode ser reproduzida sem a autorização por escrito do autor. Citações são estimuladas, desde que citada à fonte.

Nome: ELISIANE FUHRMANN

CPF: 005.381.390-13

Endereço. RUA BABAÇÚS, 459. BAIRRO PARQUE DAS ARARAS. SINOP-MT

Tel. (66) 9906-1503

Email: elisifuhrmann@hotmail.com 
Especialmente ao meu filho Benício, amor incondicional.

Aos meus pais, Olivio e Gerda, a minha irmã, Elaine, pela confiança e apoio. Ao meu amor, Murilo, pela compreensão, incentivo e carinho dedicado.

\section{DEDICO}




\section{AGRADECIMENTOS}

À Deus, pela sua presença constante em minha vida, me orientando em todos os momentos.

À Universidade de Brasília e ao Departamento de Agronomia pela oportunidade de poder realizar o curso.

À Empresa Brasileira de Pesquisa Agropecuária - CPAC, pela disponibilização de infra-estrutura no desenvolvimento científico deste trabalho.

À Coordenação de Aperfeiçoamento de Pessoal de Nível Superior (CAPES), pela concessão da bolsa de estudos.

Ao meu orientador Dr. Fábio Gelape Faleiro, pela orientação, apoio, e que desde o mestrado vem sempre me ajudando, pela experiência adquirida sob sua orientação e que muito contribuíram para a conclusão desse curso.

Ao co-orientador Dr. Eduardo Alano Vieira, sempre disponível a solucionar minhas dúvidas, pela ajuda na escolha, fornecimento do material e toda a ajuda no decorrer do curso.

Ao Dr. Luiz Joaquim Castelo Branco Carvalho, por se disponibilizar em me ajudar nas análises de carotenóides e pela experiência e amizade que muito contribuíram para o trabalho.

Ao Murilo Werneck Braga, pela ajuda no desenvolvimento dos experimentos, pelo carinho, amor e apoio incondicional.

À minha grande amiga de longa data, Cristina Schetino Bastos, pela orientação, pela amizade, incentivo durante toda a fase inicial da minha carreira profissional e por sempre ter confiado e acreditado.

Aos amigos da Embrapa Cerrados e Cenargen em especial a essa grande amiga Graciele, pela valiosa amizade e ajuda dado na condução dos experimentos.

Aos amigos e familiares, pela amizade, apoio e que mesmo a distancia sempre torceram por mim.

Aos amigos do curso de pós-graduação pela amizade e companheirismo durante estes quatro anos de muito trabalho.

Aos professores e funcionários da UnB, pela amizade e colaboração.

Aos pesquisadores, laboratoristas e amigos da Embrapa Cerrados e Cenargen, pela grande ajuda na instalação, condução e colheita do experimento de campo, que muito contribuíram para o meu crescimento profissional, científico e humano.

A todos aqueles que, de alguma forma, contribuíram para a realização deste trabalho, sempre me apoiando e incentivando. MUITO OBRIGADA! 


\section{SUMÁRIO}

Página

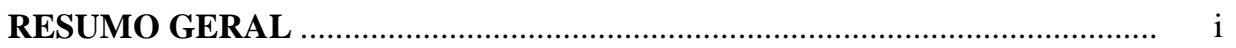

GENERAL ABSTRACT ..............................................................................

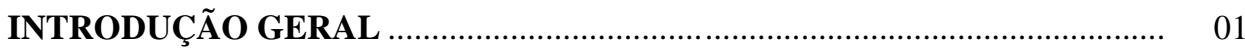

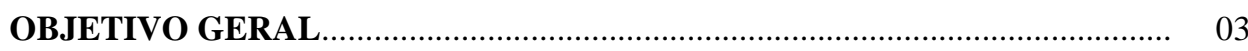

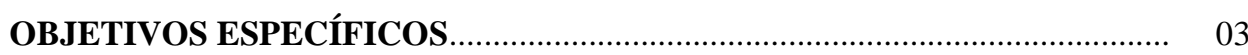

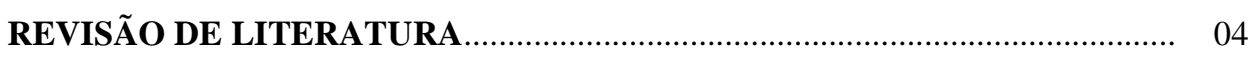

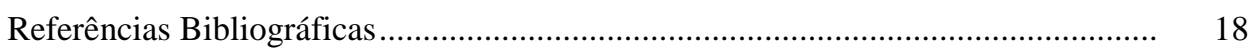

CAPÍTULO 1: CARACTERIZAÇÃO MORFOLÓGICA DE CLONES ELITE DE MANDIOCA DE MESA AMARELA BIOFORTIFICADOS .................................. 25

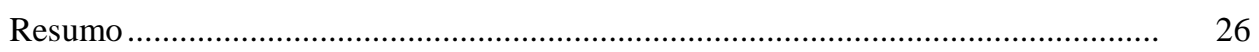

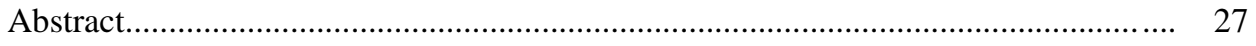

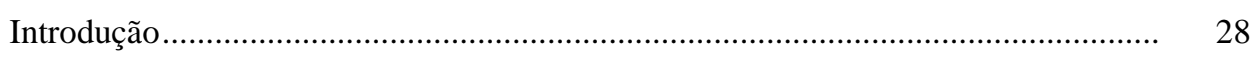

Material e Métodos ........................................................................................ 29

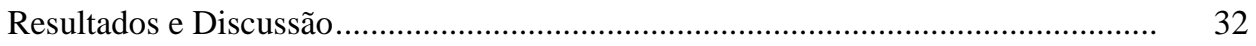

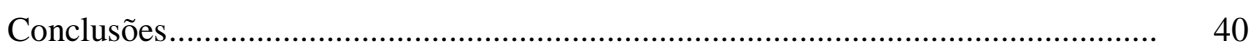

Referências Bibliográficas .................................................................................... 41

CAPÍTULO 2: CARACTERIZAÇÃO AGRONÔMICA E BIOQUÍMICA DE CLONES ELITE DE MANDIOCA DE MESA AMARELA BIOFORTIFICADOS. 44

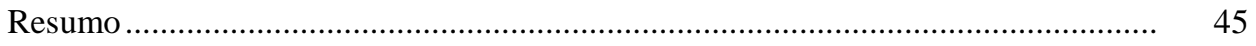

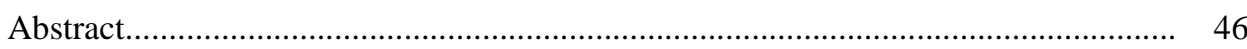

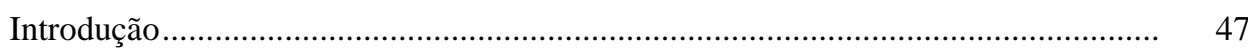

Material e Métodos .............................................................................................. 48

Resultados e Discussão.............................................................................. 51

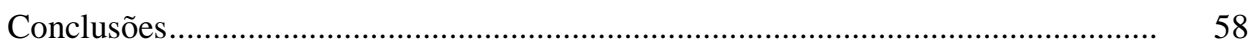

Referências Bibliográficas.............................................................................. 59

CAPÍTULO 3: CARACTERIZAÇÃO MORFOLÓGICA DE CLONES ELITE DE MANDIOCA DE MESA COM POLPA ROSADA BIOFORTIFICADAS ............. 62

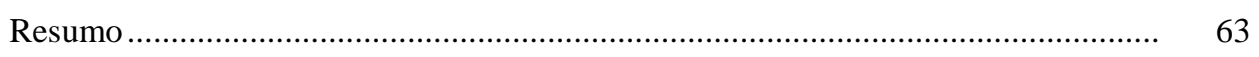

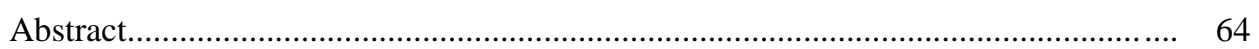

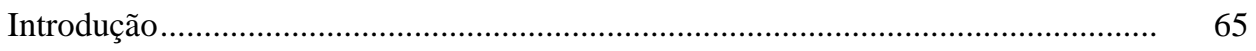

Material e Métodos ........................................................................................... 66

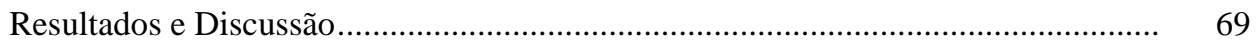

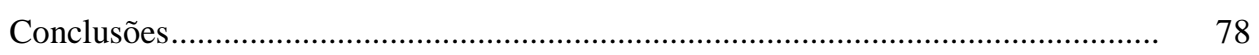

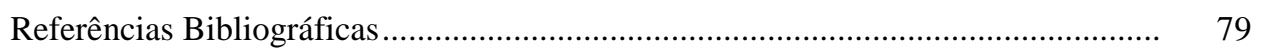


CAPÍTULO 4: CARACTERIZAÇÃO AGRONÔMICA E BIOQUÍMICA DE CLONES ELITE DE MANDIOCA DE MESA ROSADAS BIOFORTIFICADOS ................................................................................. 82

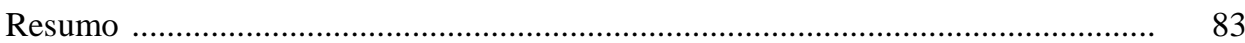

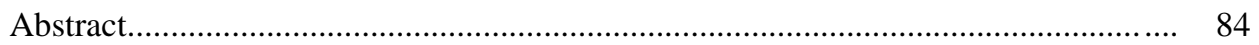

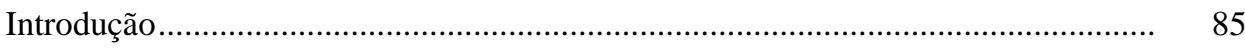

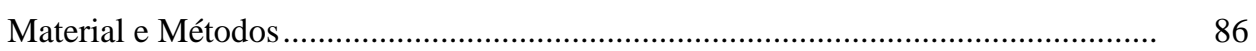

Resultados e Discussão.................................................................................... 89

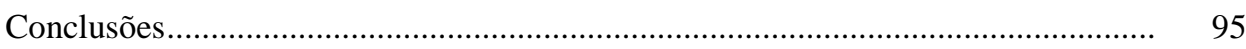

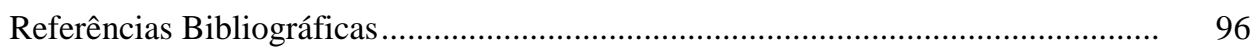

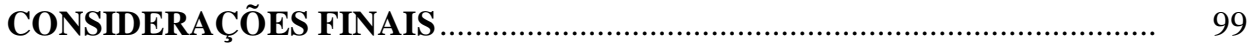




\section{CARACTERES MORFO-AGRONÔMICOS E BIOQUÍMICOS DE CLONES ELITE DE MANDIOCA DE MESA COM RAÍZES DE POLPAS AMARELADA E ROSADA}

\section{RESUMO GERAL}

A mandioca (Manihot esculenta Crantz) é considerada uma espécie relevante como fonte alimentícia para a população mundial, principalmente para os países subdesenvolvidos e emergentes. A mandioca é fornecedora de energia a partir do amido acumulado em suas raízes de reserva, mas é também importante destacar a presença dos carotenóides com atividade antioxidante. Nesse contexto, o presente trabalho teve como objetivo caracterizar, por meio de descritores morfológicos, agronômicos e bioquímicos, clones elite de mandioca de mesa de polpa aparelhada e rosada do programa de melhoramento genético de mandioca da Embrapa Cerrados. Foram caracterizados durante duas safras, 13 clones de mandioca de mesa com polpa amarelada e 8 clones com polpa rosada, em comparação com a variedade testemunha IAC 576-70 (BGMC 753). Para avaliar as características morfológicas foram obtidos 40 descritores qualitativos para cada clone. Tanto nos clones de polpas amarelada quanto naqueles de raízes de polpas rosada, houve diferenças morfológicas, demostrando que nenhum clone apresentou $100 \%$ de similaridade. O fator ano/safra não influenciou a expressão fenotípica dos caracteres aferidos. Com base no coeficiente cofenético, verificou-se elevado ajuste entre a representação gráfica via dendrograma de $r=0,80$ nas raízes de polpa amarelada e $r=0,92$ na rosada e a matriz de dissimilaridade genética. Entre os caracteres aferidos, os que apresentaram maior entropia nas raízes amarelada foram, a coloração da epiderme externa, forma do lóbulo central da folha e cor do córtex da raiz, ao passo que na rosada foi à cor do disco, forma do lóbulo central e cor do pecíolo. Foi realizada também a caracterização com base na altura da planta, altura da primeira ramificação, peso da parte aérea sem a cepa, produtividade em raízes, índices de amido nas raízes determinados por meio do método da balança hidrostática, tempo para a cocção e teor de ácido cianídrico nas raízes. Com base nos caracteres avaliados, os clones que se destacaram com polpa amarelada e rosada respectivamente, no caractere altura da primeira ramificação (273/08 e 259/08) e (390/08, 345/08 e a testemunha IAC 576-70), altura da planta (90/08, 272/08, 273/08, 497/08, 259/08 e 
450/08) e (390/08, 345/08 e 378/08), peso da parte aérea sem a cepa (94/08 e 272/08) e (390/08, 406/08, 390/08, 378/08 e 341/08), porcentagem de amido nas raízes (26/08, 272/08, 259/08 e 450/08) e (378/08, 413/08, 390/08 e a testemunha IAC 576-70), produtividade de raízes (215/08) e (testemunha IAC 576-70, 341/08, 406/08, 390/08 e 387/08). Com relação ao tempo de cocção na safra 2011/2012, todos os clones necessitaram de tempo inferior a 30 minutos. Em relação ao teor de carotenóides totais nas raízes os clones de amarelada que se destacaram foram 91/08, 94/08, 215/08, 246/08, 272/08 e 497/08, e, naqueles de raízes rosada, os clones 406/08 e 341/08. Em relação ao teor de proteínas nas raízes amarelada, os clones 26/08, 90/08 e 91/08, foram os melhores enquanto nas raízes rosada se destacaram os clones 406/08 e a testemunha IAC 576-70. Os teores de $\mathrm{HCN}$ nas raízes de reserva de mandioca foram inferiores a $100 \mathrm{mg} \mathrm{kg}^{-1}$ em todos os clones avaliados. Diferenças significativas entre clones de mandioca de polpas amarelada e rosada foram verificadas para todas as características agronômicas, morfológicas e bioquímicas avaliadas. Os clones tiveram bom desempenho nas avaliações para o cultivo comercial na região do Cerrado e, alguns destes, têm potencial para utilização no melhoramento visando o incremento de carotenóides.

Palavras-chave: Manihot esculenta Crantz, melhorameto genético, caracteres morfológicos, caracteres agronômicos, caracteres bioquímicos, biofortificação, recursos genéticos 


\section{MORPHO-AGRONOMIC AND BIOCHEMICAL CHARACTERS IN SWEET CASSAVA ELITE CLONES WITH YELLOWISH AND PINKISH PULPS}

\section{GENERAL ABSTRACT}

Cassava (Manihot esculenta Crantz) is considered a relevant species as a food source for the world's population, particularly for developing and emerging countries. The cassava is a provider of energy from starch accumulated in their reserve roots, but it is also important to highlight the presence of carotenoids with antioxidant activity. In this context, this study aimed to characterize, using morphological, agronomic and biochemical, descriptors elite clones from sweet cassava of yellowish and pinkish pulps from the cassava breeding program at Embrapa Cerrados. They were characterized for two crops, 13 edible cassava clones with yellowish pulp and 8 clones with pinkish pulp, compared with the control variety IAC 576-70 (BGMC 753). To evaluate the morphological characteristics were obtained 40 qualitative descriptors for each clone. Both clones the yellowish pulp as those the roots the pinkish pulp, there was morphological differences among clones, showing that no clone showed $100 \%$ similarity. The year / crop factor did not influence the phenotypic expression of measured characters. Based on cofenetic coefficient, was found high fit between the graphical representation via dendrogram of $r=0.80$ in the roots of yellowish pulp and $r$ $=0.92$ in the pinkish of genetic dissimilarity matrix. Among the measured characters, those with the highest entropy in the yellowish roots were, the color of the outer epidermis, the central lobe shape of the leaf and root cortex color, whereas the pinkish was the color to disc, central lobe shape and petiole color. We also performed the characterization based on plant height, the first branch point, and shoot weight without strain, productivity in roots, and index of starch in the roots determines by the method of hydrostatic balance, time for cooking and acid cyanide content in the roots. Based on the evaluated characters, clones stood out with pulps yellowish and pinkish respectively, characters height of the first branch (273/08 and 259/08) and (390/08, 345/08 and the witness IAC 576-70), plant height (90 / 08, 272/08, 273/08, 497/08, 259/08 and 450/08) and (390/08, 345/08 and 378/08), shoot weight without strain (94/08 and 272/08) and (390/08, 406/08, 390/08, 378/08 and 341/08), percentage of starch in the roots $(26 / 08$, 272/08, 259/08 and 450/08) and (378/08, 413/08, 390/08 and the witness IAC 576-70), 
roots of productivity (215/08) and (witnesses IAC 576-70, 341/08, 406/08, 390/08 and 387/08). Regarding the cooking time in the 2011/2012 harvest, all clones showed time less than 30 minutes. Regarding the total carotenoid content in the pulps clones of yellowish roots that stood out were 91/08, 94/08, 215/08, 246/08, 272/08 and 497/08, and, those the clones with pulp pinkish 406/08 and 341/08. Regarding the protein content in yellowish roots the clones $26 / 08,90 / 08$ and 91/08, was the best while the pinkish roots highlight clones 406/08 and witness IAC 576-70. The levels of HCN in reserve roots of cassava were less than $100 \mathrm{mg} \mathrm{kg}-1 \mathrm{em}$ all evaluated clones. Significant differences between yellowish and pinkish of pulps cassava clones were checked for all agronomic, morphological and biochemical characteristics evaluated. The clones had well in the ratings for commercial cultivation in the Cerrado region and some of these, clones has potential for use in breeding aimed at increase of carotenoids.

Key words: Manihot esculenta Crantz, genetic melhorameto, characterize morphological, characterize agronomic, characterize biochemical, biofortified, genetic resources 


\section{INTRODUÇÃO GERAL}

A mandioca de mesa (Manihot esculenta Crantz), também conhecida popularmente no Brasil por aipim e macaxeira, é uma espécie cultivada mundialmente nas regiões tropicais, pertencente à família Euphorbiaceae, sendo a única espécie cultivada dentro do gênero Manihot. A sua alta heterozigosidade, favorecida pelos cruzamentos naturais intra-específicos e propagação vegetativa, resultou em um grande número de variedades com diferentes características morfológicas, permitindo adaptação às diversas condições de clima e solo, bem como resistência e/ou tolerância a pragas e doenças (LORENZI, 2003). É considerado um alimento de subsistência para mais de 500 milhões de pessoas nas áreas tropicais, sendo a produção mundial em 2012 cerca e 229 milhões de toneladas (FAOSTAT, 2012).

A cultura da mandioca é muito importante em países em desenvolvimento, principalmente em função da sua rusticidade e da capacidade que apresenta de produzir razoavelmente bem em condições em que outras culturas não sobreviveriam. Tal habilidade advém da espécie ser naturalmente tolerante a solos ácidos e à seca e ao mesmo tempo oferecer uma flexibilidade de colheita aos produtores (CEBALLOS et al., 2004). No Brasil (centro de origem e de diversidade da espécie), a mandioca é cultivada em praticamente todas as regiões, ocupando papel de destaque na alimentação humana e animal (LORENZI \& DIAS, 1993). No gênero Manihot já foram identificadas cerca de 98 espécies (ROGERS \& APPAN, 1973).

O cultivo da mandioca no Brasil remonta ao período pré-colonial e teve sempre um importante papel na alimentação do povo indígena brasileiro devido à sua grande fonte de carboidratos e às suas múltiplas aplicações junto às populações rurais (MURRIETA, 2001). A mandioca tem características de subsistência nas regiões Amazônica e Nordeste (com cerca de $40 \%$ da produção nacional), enquanto no Distrito Federal, o cultivo de mandioca caracteriza-se por estar concentrado em pequenas propriedades que utilizam mão-de-obra familiar e em cultivares de mandioca de mesa para consumo "in natura", em uma área cultivada anualmente em cerca de 850 ha, com uma produtividade média de $16 \mathrm{t} \mathrm{ha}^{-1}$ (SOUSA et al., 2005). A produção se destina principalmente a feiras livres do Distrito Federal (26,40\%), a agroindústrias familiares onde é minimamente processada $(23,10 \%)$, a exportação para outras cidades do entorno $(11,5 \%)$, a venda a comerciantes (atravessadores) (10,40\%), sendo o restante vendido em comércio de hortifrutigranjeiros, supermercados, casas de farinha entre outros (AGUIAR et al., 2005). 
A mandioca sempre foi cultivada em razão de suas raízes de reservas ricas em amido, porém pobres em proteínas e vitaminas. Entretanto, nos últimos anos, as pesquisas com a cultura tomaram um novo rumo, uma vez que foi descoberto que as raízes de mandioca também podem constituir-se em uma fonte potencial de carotenóides, como o betacaroteno, precursor da vitamina A, nas raízes de coloração amarela e o licopeno nas raízes de coloração rosada (CARVALHO et al., 2000). Dessa forma, a cultura vem destacando-se dentre os vegetais como uma importante fonte carotenoides, associados a diversos fatores de proteção à saúde humana.

Por ser considerado o seu centro de origem, o Brasil apresenta grande diversidade genotípica para está espécie, sendo de grande relevância a caracterização dessa diversidade visando à conservação de genótipos e alelos, além de fornecer informações aos programas de melhoramento genético. Essa diversidade genética encontra-se disponível no grande número de variedades cultivadas por agricultores tradicionais, parte delas coletadas e mantidas em bancos de germoplasma. $\mathrm{O}$ banco de germoplasma de maior magnitude no Brasil pertence à Empresa Brasileira de Pesquisa Agropecuária (EMBRAPA) com cerca de 3000 acessos (GALERA \& VALLE, 2007).

Como um dos principais fatores que limitam a produtividade da cultura na região do Cerrado é a ausência de variedades adaptadas, foi estabelecido em 2006 um programa de melhoramento genético de mandioca para a região na Embrapa Cerrados. Em relação a variedades de mesa, o programa vem gerando e selecionando constituições genéticas com elevado potencial agronômico e com a coloração das raízes amarelas biofortificadas (VIEIRA et al., 2011b). O trabalho de caracterização tem mostrado o potencial dos genótipos de mandioca no desenvolvimento de novas variedades para mesa com ótimas características agronômicas e nutricionais adaptadas à região do Cerrado. Nesse contexto, a obtenção de clones adaptados à região assume importância estratégica, além de avaliados agronomicamente esses clones elite necessitam ser avaliados com a utilização simultânea de descritores morfológicos e caracteres bioquímicos a fim de gerar informações a cerca da possibilidade da utilização no melhoramento genético e recomendação como novas variedades de mandioca de mesa. 


\section{OBJETIVO GERAL}

Avaliar agronomicamente, morfologicamente e bioquimicamente, clones elite de mandioca de mesa de polpa amarelada e rosada do programa de melhoramento genético de mandioca da Embrapa Cerrados.

\subsection{Objetivos específicos}

- Avaliar a influência ambiental e genética no desempenho agronômico de clones elite de mandioca de mesa com coloração da polpa das raízes de reserva amarelada e rosada.

- Identificar clones com potencial para uso no melhoramento genético e/ou para a recomendação como novas variedades.

- Verificar a existência de variabilidade quanto a descritores morfológicos entre clones elite de mandioca de mesa com coloração da polpa das raízes de reserva amarelada.

- Verificar a existência de variabilidade quanto a caracteres morfológicos entre clones elite de mandioca de mesa com coloração da polpa das raízes de reserva rosada.

- Verificar a existência de variabilidade entre os clones elite de mandioca de mesa com coloração da polpa das raízes de reserva amarelada quanto à quantidade de carotenóides totais, proteína, amido e ácido cianídrico nas raízes.

- Verificar a existência de variabilidade entre os clones elite de mandioca de mesa com coloração da polpa das raízes de reserva rosada quanto à quantidade de carotenóides totais, proteína, amido e ácido cianídrico nas raízes. 


\section{REVISÃO DE LITERATURA}

\subsection{Produção de mandioca de mesa}

A mandioca (Manihot esculenta Crantz) é uma planta da família Euphorbiaceae e segundo MORAES-DALLAQUA \& CORAL (2002), a raiz adventícia dessa planta apresenta o padrão anatômico normal de desenvolvimento até o início do processo de tuberização, estabelecendo-se uma diferenciação maior das células parenquimáticas do xilema para o acúmulo de grão de amido. Essa planta desempenha um importante papel na dieta alimentar dos brasileiros por seu alto valor energético. O Brasil é o segundo maior produtor mundial de mandioca com produção de 26,9 milhões de toneladas em 2012 (IBGE, 2015), sendo a Nigéria o maior produtor mundial com uma produção aproximada de 39 milhões de toneladas.

A cultura da mandioca está em franca expansão no Mundo e sua importância cresce a cada ano. Os dados comparativos do FOAOSTAT (2010) referentes aos anos de 1961 a 2010 no Mundo mostram uma taxa de crescimento médio anual de 2,47\% para produção, para área houve aumento de 1,37\%, produtividade de 1,09\% e consumo per capita de 0,33\%, mostrando um crescente aumento da cultura da mandioca no Mundo num período de 49 anos (Tabela 1).

Tabela 1. Produção, área colhida, produtividade, consumo per capita e taxa de crescimento médio anual, referente à safra de mandioca de 1961 e 2010, no Mundo.

\begin{tabular}{ccccc}
\hline Ano & $\begin{array}{c}\text { Produção } \\
\text { (ton) }\end{array}$ & Área (ha) & $\begin{array}{c}\text { Produtividade } \\
\text { (ton/ha) }\end{array}$ & $\begin{array}{c}\text { Consumo per capita } \\
\text { (Kg/hab./ano) }\end{array}$ \\
\hline 1961 & 71.259 .855 & 9.623 .855 & 7,4 & 12,3 \\
2010 & 229.540 .896 & 18.457 .612 & 12,4 & 14,4 \\
$\begin{array}{c}\text { Taxa de crescimento médio } \\
\text { anual no período (\%) }\end{array}$ & 2,47 & 1,37 & 1,09 & 0,33 \\
\hline
\end{tabular}

Fonte: FAOSTAT (2010).

A estimativa de produção de mandioca em 2013 para a região nordestina deve alcançar quase 7 milhões de toneladas, indicando uma redução de $8,1 \%$ em relação a fevereiro, reflexo da estiagem que se prolonga em diversos municípios produtores do Piauí e da Bahia. Esses dois Estados estão reduzindo suas estimativas em 121.077 e 553.333 toneladas, respectivamente, frente à informação de fevereiro. Somente a Bahia está estimando uma redução de 18,9\%. Ainda que venha a se normalizar o regime de 
chuvas no Nordeste, o fato da mandioca ser uma cultura temporária de longa duração, tendo seu ciclo normal entre 12 e 18 meses, prejudica uma retomada mais veloz da produção em níveis adequados ao suprimento da demanda. Por outro lado, a perda de grandes extensões de lavouras em 2012 em função da seca, reduziu consideravelmente a oferta de manivas-sementes em muitos municípios, o que tem dificultado a reposição de plantios e implantação de novas lavouras, o que também prejudica a retomada da produção da mandioca no curto prazo. Na região Sul, em Santa Catarina está prevista uma produção $27,1 \%$ menor que a informação de fevereiro. Os levantamentos de campo indicaram uma redução de 30,1\% na área a ser colhida no Estado. A Região Norte, principal produtora de mandioca, também apresenta decréscimo de 3,7\% na estimativa de produção, influenciada notadamente por Amazonas e Pará (IBGE, 2013).

O consumo culinário de raízes de mandioca é bastante generalizado em todo o mundo, sendo essa raiz amplamente utilizada na forma cozida, assada, frita ou integrando pratos mais complexos. Atualmente, a mandioca para uso culinário é comercializada como vegetal fresco ou minimamente processada, refrigerada ou congelada, ou também na forma pré-cozida facilitando o preparo e consumo.

Buscando atender as mudanças de mercado, novos produtos alimentares estão sendo testados e inovados a fim de suprir a demanda existente. Os produtos brutos (in natura) cedem progressivamente lugar para os produtos pré-aquecidos e pré-elaborados, denominadas minimamente processados. Como resultado das pesquisas alimentícias desenvolvidas no mundo todo, a demanda de frutas e vegetais minimamente processados, ou também chamados de vegetais e frutas de quarta geração, vem aumentando largamente (PRIGENT, 1992).

O processamento industrial da mandioca de uso culinário aumentou muito nos últimos anos, principalmente nos grandes centros urbanos como São Paulo, Rio de Janeiro, Brasília, Belo Horizonte, entre outros. As principais formas de processamento são in natura (sem a casca), minimamente processadas, resfriadas, congeladas cruas, congeladas depois de cozidas (fritas e pedaços), esterilizadas a vácuo e fritas (chips) (VILPOUX \& CEREDA, 2002).

Constatou-se que, além de carboidratos, a cultura da mandioca é uma excelente fonte de carotenóides nas raízes de coloração amarela (CHÁVEZ et al., 1999). Foi comprovado também que a coloração amarela das raízes apresenta uma alta correlação com o teor de carotenóides totais nas raízes e que a maior parte destes é composta pelo betacaroteno, o principal precursor da vitamina A (CARVALHO et al., 2005). A ocorrência de deficiência de Vitamina A no Brasil, onde a mandioca é cultivada e faz 
parte do hábito alimentar destas populações, coloca esta cultura em posição privilegiada com alternativa viável no combate a fome e como fonte de nutrientes destas populações.

Variedades de mandioca de mesa destinadas à comercialização das raízes, além de bom desempenho agrícola exigido pelo produtor, como boa produtividade, resistência a pragas e doenças, uniformidade e padrão comercial das raízes e facilidade de práticas culturais, também devem atender às exigências sensoriais e tecnológicas do consumidor final, demonstrando sabor característico, textura macia e cozimento rápido (LORENZI \& VALLE, 2002).

\subsection{Origem e o gênero Manihot}

As plantas cultivadas, onde os recursos aproveitados são as raízes e tubérculos, se originaram nos trópicos, sendo que a domesticação ocorreu de forma independente em três regiões distintas: Sudeste da Ásia, África (Madagascar) e América Tropical (LÉON, 1977). A América Tropical merece destaque por ser a área onde ocorreu a origem e domesticação da mandioca e da batata (Solanum tuberosum) (CLEMENT et al., 2010).

Dentro da sistemática botânica de classificação hierárquica, a mandioca pertence à classe Dicotiledonea, à subclasse Archiclamydae, à ordem Euphorbiales, à família Euphorbiaceae, à tribo Minihoteae, ao gênero Manihot e à espécie Manihot esculenta Crantz.

No gênero Manihot já foram identificadas cerca de 98 espécies (ROGERS \& APPAN, 1973). De acordo com ALLEM (2002), o Brasil abriga a grande maioria das espécies, aproximadamente 68 , o que corresponde a $80 \%$ da diversidade conhecida. $\mathrm{O}$ México vem em seguida com 17 espécies e 15\% da diversidade. A maior parte das espécies ocorre no norte da América do Sul, enquanto que um centro secundário de diversidade do gênero ocorre na América Central e no México (OLSEN \& SCHAAL, 1999; OLSEN, 2004). Um estudo da distribuição geográfica do gênero realizado por NASSAR (2001) concluiu que do total de 98 espécies, 38 ocorrem no sul de Goiás e leste de Minas Gerais, representando, portanto, uma região de alta diversidade do gênero Manihot. De acordo com OLSEN (2004), o provável centro de origem da mandioca seria a região sudeste da Amazônia.

O gênero Manihot foi dividido em dois grupos gênicos. O grupo gênico primário inclui as espécies que se intercruzam com facilidade, gerando híbridos férteis, como as espécies $M$. esculenta ssp. esculenta, M. esculenta ssp. flabellifolia, M. esculenta ssp. 
peruviana e $M$. pruinosa. O grupo gênico secundário, que envolve as espécies que se cruzam mas são distantes geneticamente, inclui as espécies: M. triphylla, M. pilosa, M. brachyloba, M. anomala, M. epruinosa, M. gracilis, M. tripartita, M. leptophylla, M. pohlii, M. glaziovii, M. dichotoma, M. aesculifoia e M. chlorosticta. Manihot esculenta Crantz é a única espécie desse gênero cultivada comercialmente para a produção de raízes comestíveis e apresenta as seguintes sinonímias: $M$. utilissima, M. edulis e $M$. aipi. É conhecida na América Latina como mandioca (Brasil) e yuca; no Continente Norte-Americano e países da Europa, como cassava, manioc, manioca e tapioca; e países da Ásia e da África, como suahili, mhogo e omowgo (DOMINGUEZ et al., 1982).

Estudos de caracterização de mandioca incluindo polimorfismo de comprimento de fragmento amplificado - AFLP (ROA et al., 1997) e microssatélites (ROA et al., 2000), usando quatro espécies de mandioca da América do Sul (M. esculenta silvestre, M. tristis, M. carthaginensis e M. brachyloba), além da M. aesculifolia, confirmaram o ponto de vista de Allem (1994b), de que a mandioca está diretamente relacionada com o que ele considera $M$. esculenta silvestre. Apenas uma pequena porção do marcador molecular difere entre as formas silvestres e cultivadas da M. esculenta. CARVALHO et al. (2000) comprovaram que a M. esculenta ssp. flabellifolia é o ancestral da espécie cultivada.

De acordo com ALLEM \& GOEDERT (1991), a mandioca é uma espécie cultígena de origem americana. Não se encontra sob a forma silvestre e aparentemente evoluiu como uma espécie cultivada, por seleção natural e com o cuidado do homem (HERSHEY \& AMAYA, 1982). Foi domesticada por povos pré-colombianos, visando à produção de raízes a partir de espécies silvestres do gênero Manihot. Evidências arqueológicas encontradas na Colômbia e Venezuela indicam que o cultivo da mandioca é praticado nessas regiões há cerca de 3000 a 7000 anos (REICHEL-DOLMANTOFF, 1957; RENOVOIZE, 1973).

Em todos os cultivos do Hemisfério Ocidental os agricultores costumam classificar as variedades de mandioca em mansas e bravas, de acordo com o teor de ácido cianídrico contido em raízes, não havendo nenhuma relação com a sua classificação taxonômica (ROGERS \& APPAN, 1973). As espécies do gênero Manihot apresentam ampla variabilidade genética para caracteres de interesse agronômico e perspectivas promissoras de introgressão na espécie M. esculenta (MENDES, 1982; BYRNE, 1984). 


\subsection{Caracteres morfológicos e agronômicos}

Os marcadores genéticos tem uma aplicação muito importante na caracterização de recursos genéticos, além de proporcionarem dados básicos que são necessários ao melhoramento de plantas ou para o mapeamento de genes. As variações fenotípicas desempenham um importante papel na definição e no alcance dos objetivos do melhoramento de uma espécie (HALLAUER, 1992). Em função do crescimento da população humana e das modificações do meio ambiente, a variação fenotípica em bancos de germoplasma deve ser explorada de forma a atender as futuras necessidades da alimentação humana (FREY, 1992), especialmente visando à geração de variedades mais produtivas, com qualidade específica, resistência a pragas e doenças, adaptações a diferentes ambientes, entre outras.

Descritores morfológicos podem ser entendidos como toda característica que permite identificar e diferenciar facilmente os acessos no campo, geralmente possuem alta herdabilidade e envolvem a expressão de um ou mais genes pouco influenciada pelo ambiente. A integração desses descritores morfológicos com os descritores bioquímicos e moleculares, acompanhados pelos dados de passaporte, constitui uma ferramenta valiosa na caracterização de recursos genéticos e identificação de acessos duplicados nas coleções (FUKUDA \& GUEVARA, 1998).

Os descritores agronômicos consistem basicamente de caracteres com baixa herdabilidade, desejáveis sob o ponto de vista econômico, envolvendo a expressão de diferentes genes influenciada pelas condições ambientais. Estes descritores agronômicos contribuem para visualizar de forma preliminar a adaptação e o potencial produtivo dos genótipos, pondo em evidencia os mais promissores indicados para recomendação direta ao produtor e/ou utilização em programas de hibridações (FUKUDA \& GUEVARA, 1998).

As características morfológicas são os marcadores genéticos mais comumente utilizados na caracterização de recursos genéticos de bancos de germoplasma das mais diversas culturas. Suas principais vantagens residem no fato de serem simples, rápidos e com baixo custo de análise (BRETTING \& WIDRLECHENER, 1995). Já os caracteres agronômicos são de grande importância econômica para a cultura e apresentam uma variação fenotípica não somente determinada pelos genes dos indivíduos, mas também influenciada pelo ambiente (BORÉM, 1997).

Recentemente, o International Plant Genetic Resources Institute (IPGRI) fez uma revisão dos descritores de mandioca, e a nova versão foi elaborada, na qual 75 
descritores foram definidos, sendo 54 morfológicos e 21 agronômicos. Descritores morfológicos (por exemplo, forma do lóbulo, coloração da polpa da raiz, coloração da haste externa), tem uma alta herdabilidade, enquanto os descritores agronômicos (tais como comprimento da raiz, número de raízes por planta e rendimento de raiz) apresentam menor herdabilidade por serem mais influenciados pelo ambiente. Dentre os descritores morfológicos, foram definidos um número mínimo ou básico descritores que deve ser considerado para a caracterização dos recursos genéticos: (i) coloração apical da folha, (ii) pubescência da folha apical, (iii) forma do lóbulo central, (iv) coloração do pecíolo, (v) coloração do córtex da haste, (vi) coloração externo do caule, (vii) comprimento filotaxia, (viii) presença de pedúnculo na raiz, (ix) coloração externa da raiz, (x) coloração do córtex da raiz, (xi) coloração da polpa da raiz, (xii) textura da epiderme da raiz e (xiii) floração (ALVES, 2002).

Diversos trabalhos realizados com mandioca apresentam a caracterização morfológica como forma de determinação da diversidade genética entre genótipos coletados nas mais diferentes regiões do país (VIEIRA et al., 2008; ALBUQUERQUE et al., 2009; SIVIERO \& SCHOTT, 2011).

No trabalho realizado por VIEIRA et al. (2008), oito acessos de mandioca mantidos no Banco de Germoplasma de Mandioca da Embrapa Cerrados foram caracterizados utilizando 33 caracteres morfológicos. Os resultados demonstraram que do total de caracteres avaliados, 22 apresentaram variabilidade entre os acessos, o que permitiu a diferenciação dos acessos e revelou uma ampla divergência entre eles.

Os descritores agronômicos são importantes quando se visa os programas de melhoramento genético de mandioca e o futuro lançamento de novas variedades (OJULONG et al., 2008; ALBUQUERQUE et al., 2009; KAWUAKI et al., 2011)

Em estudo cujo objetivo era indicar variedades de mandioca para o consumo e/ou como genitores em programas de melhoramento, SILVA et al. (2013) avaliaram 13 acessos de mandioca quanto aos caracteres altura da primeira ramificação, altura da planta, massa da parte aérea, produtividade de raízes, porcentagem de amido nas raízes, severidade de bacteriose, teor de carotenóides nas raízes, tempo de cocção e teor de ácido cianídrico nas raízes. Os resultados evidenciaram a existência de diferenças significativas para todas as características, com exceção da severidade da bacteriose e do teor de carotenoides nas raízes. Nenhum acesso apresentou desempenho agronômico que justificasse o cultivo comercial, mas alguns acessos apresentaram potencial para uso no melhoramento, sendo os acessos BGMC 1221, BGMC 1223, BGMC 1224 como fontes de $\beta$-caroteno e os acessos BGMC 1222 e BGMC 1229 como fonte de licopeno. 
RIMOLDI et al. (2010) avaliaram a similaridade genética de 14 cultivares de mandioca a partir de 12 caracteres morfo-agronômicos e concluíram que dois cruzamentos seriam promissores (cultivares Branca 3 versos Pão e Amarela 1 e Fécula Branca versos Amarela 2) por apresentarem alta divergência genética e favoráveis características agronômicas, culinárias e resistência a doença em pelo menos um dos parentais envolvidos no cruzamento.

\subsection{Melhoramento genético da mandioca}

A mandioca constitui um importante cultivo nos trópicos e os agricultores sempre estiveram envolvidos no seu processo de seleção e na conservação de variedades, desde os seus ancestrais mais remotos. Os progressos no melhoramento genético para adaptação e qualidade ocorreram durante séculos de seleção nas Américas e durante os últimos 300 anos na África e Ásia, resultando em uma ampla diversidade genética (BONIERBALE et al., 1995). Um dos primeiros informes sobre avaliação e seleção de variedades de mandioca foi editado no Estado da Bahia, Brasil, datado de 1899 (ZEHNTNER, 1919). Mas, foi a partir do século 20 que instituições nacionais começaram a organizar-se para melhorar esse cultivo por meio de melhoramento genético. Em meados do século 20, iniciou-se um programa ativo de melhoramento da mandioca no Brasil (NORMANHA, 1970) e em parte da África, conduzido em algumas colônias.

O melhoramento genético da cultura da mandioca tem se desenvolvido em diferentes estágios, tais como avaliação de variedades "landraces" (nativas), coletadas e intercâmbio de germoplasma regional e global, recombinação e seleção de clones e uso de espécies silvestres para ampliar a base genética. A partir dos anos 80, a biotecnologia tem sido desenvolvida e aplicada para facilitar e aumentar a eficiência do melhoramento da mandioca. Como consequência, novos horizontes têm sido abertos para o melhoramento da mandioca (FUKUDA \& IGLESIAS, 2006; VIEIRA et al., 2011).

Os métodos de melhoramento de uma cultura são definidos basicamente em função de modo de reprodução da espécie, da variabilidade genética disponível, do modo de propagação e dos objetivos do programa. Em mandioca, alguns fatores influenciam a escolha dos métodos de melhoramento tais como as características genéticas e citogenéticas da espécie, o nível de endogamia, o hábito de florescimento e de polinização das plantas, a baixa taxa de produção de sementes por propagação vegetativa (FUKUDA, 1999). 
Não existem métodos clássicos de melhoramento desenvolvidos especificamente para culturas de propagação vegetativa. Normalmente os métodos desenvolvidos para culturas alógamas, se aplicam a mandioca, modificados em função de suas características específicas.

Os principais métodos de melhoramento utilizados na cultura da mandioca no Brasil são a introdução e seleção de variedades e as hibridações intraespecíficas (FUKUDA \& IGLESIAS, 2006; VIEIRA et al., 2011).

A estrutura orgânica reprodutiva de $M$. esculenta é típica de espécies alógamas. No entanto, para fins de melhoramento genético, a taxa de cruzamento é facilmente manejável, permitindo desde 100\% de autofecundação até 100\% de alogamia (VALLE, 1990).

A mandioca é uma espécie monóica, com flores masculinas e femininas dispostas na mesma inflorescência. As flores masculinas são formadas na parte superior das inflorescências, em maior número, enquanto que as flores femininas encontram-se na parte basal, em número inferior. A espécie apresenta protogenia, ou seja, as flores femininas abrem antes das flores masculinas (KAWANO et al., 1978; FUKUDA, 1980). Entretanto, entre as inflorescências da mesma planta pode ocorrer a abertura simultânea das flores masculinas e femininas. Desta forma, tanto a autofecundação como o cruzamento ocorrem naturalmente (PEREIRA, 1989). A mandioca é considerada uma espécie preferencialmente alógama e altamente heterozigota, em função do caráter protogínico da antese floral e da forte depressão endogâmica ocasionada pelas autofecundações, apesar de não existir nenhuma barreira genética ou fisiológica que impeça a ocorrência de autofecundações (KAWANO, 1982). A forte depressão endogâmica, em adição à sua forma de propagação vegetativa, atua como um mecanismo biológico pelo qual a alta taxa de heterozigose da espécie é mantida (KAWANO et al., 1978).

Os trabalhos de melhoramento genético com a cultura da mandioca no Brasil iniciaram em meados do século 20 (NORONHA, 1970), sendo intensificados nos anos 40 por instituições de pesquisa regionais que procuram atender as demandas de cada região (FUKUDA \& PORTO, 1991; FUKUDA, 1992), concentrando-se, inicialmente na introdução e avaliação do germoplasma disponível (FUKUDA, 1996) e atualmente na recombinação e seleção de genótipos promissores (FUKUDA et al., 2002; VIEIRA et al., 2011a). 


\subsection{Análises químicas da mandioca}

\subsubsection{Amido}

A mandioca apresenta raízes de reserva que são o principal órgão de armazenamento dos carboidratos produzidos. Pela legislação brasileira, o carboidrato de reserva de raízes é denominado fécula e por ser de fácil extração e purificação sua importância no setor alimentar e industrial tem aumentado.

Na indústria alimentícia, o amido é utilizado em função da viscosidade, poder geleificante, adesão, tendência a retrogradação, entre outras propriedades que são influenciadas pela proporção amilose/amilopectina, teor de proteína e gordura além da estrutura, forma e tamanho dos grânulos. Embora o amido seja quimicamente constituído apenas por glicose, em sua extração comercial permanecem resíduos da estrutura celular vegetal, na forma de impurezas. Apesar de se apresentarem em teores abaixo de $2 \%$, essas impurezas podem influenciar as propriedades do amido (DAIUTO et al., 2002).

O amido é formado principalmente por dois polímeros, a amilose e amilopectina, distribuídos em diferentes proporções no grânulo. A funcionalidade do amido, assim como sua organização física na estrutura granular, é em grande parte atribuída à proporção destes dois polímeros (BILIADERES, 1991).

Entre os fatores exógenos que influenciam nas características do amido citam-se a fonte botânica, que inclui além de espécies, o efeito varietal de uma mesma espécie, o tempo de cultivo e condições edafo-climáticas. Há também indicações de que amidos extraídos de raízes de algumas cultivares de mandioca apresentam características físicoquímicas e morfológicas mais constantes ao longo do período de colheita comercial, se comparadas a outras (SARMENTO, 1997).

\subsubsection{Carotenóides}

Os carotenóides são moléculas geralmente tetraterpenóides de 40 átomos de carbono, podendo ter coloração amarela, laranja ou vermelha (Figura 1). Estes são encontrados em vegetais, sendo classificados em carotenos e xantofilas. O $\beta$-caroteno e o licopeno são exemplos de carotenos, enquanto a luteína e a zeaxantina são xantofilas. Os carotenóides são sensíveis à luz, temperatura e acidez, além de serem insolúveis em água e solúveis em solventes, como acetona, álcool e clorofórmio (AMBRÓSIO et al., 2006). 
De acordo com CARVALHO (1996), as diferenças nas estruturas dos carotenoides pró-vitamínicas lhes conferem diferentes capacidades de conversão em vitamina A. BAUERNFEIND (1972) descreve que o $\beta$-caroteno possui $100 \%$ de atividade vitamínica $\mathrm{A}$, ou seja, a totalidade de $\beta$-caroteno é convertida em vitamina $\mathrm{A}$. Além deste, diversos outros carotenóides possuem atividade pró-vitamínica, sendo o $\alpha$ caroteno, o segundo com maior atividade vitamínica, cerca de $50 \%$.

A vitamina A é uma vitamina lipossolúvel, sem valor energético, que o organismo humano sintetiza em quantidade insuficiente, ou mesmo não a sintetiza sendo necessárias quantidades mínimas, as quais podem ser fornecidas pelos alimentos.

As deficiências de vitaminas, em especial de vitamina A, têm merecido destaque, devido ao número crescente de evidências que comprovam o seu impacto negativo na saúde de grupos de maior vulnerabilidade nutricional como: gestantes, recém-nascidos, e crianças na idade pré-escolar (RAMALHO et al., 2002). Ainda segundo RAMALHO et al. (2002), foi encontrada em todas as regiões brasileiras a carência de vitamina A. De acordo com AMBRÓSIO et al. (2006), os níveis diários adequados de vitamina A para prevenir sintomas de deficiência em crianças são de 200 a $300 \mu \mathrm{g}$; em adultos, de 500 a $600 \mu \mathrm{g}$; em gestantes, $550 \mu \mathrm{g}$ e cerca de $900 \mu \mathrm{g}$ em lactantes.

Os teores de $\beta$-caroteno (pró-vitamina $\mathrm{A}$ ) nas raízes de mandioca é um caráter governado por poucos genes e de fácil manipulação pelos métodos convencionais de melhoramento genético. Segundo CEBALLOS (2005), em apenas um ano de trabalho, os teores de carotenóides em raízes de mandioca foram elevados de 10,7 $\mu \mathrm{g} / \mathrm{g}$ para 16 $\mu \mathrm{g} / \mathrm{g}$, em base a peso fresco. Com isso, estima-se que é possível obter-se variedades de mandioca com teores mais elevados de carotenóides nas raízes, superiores àqueles já encontrados no germoplasma nativo (variedades crioulas). 

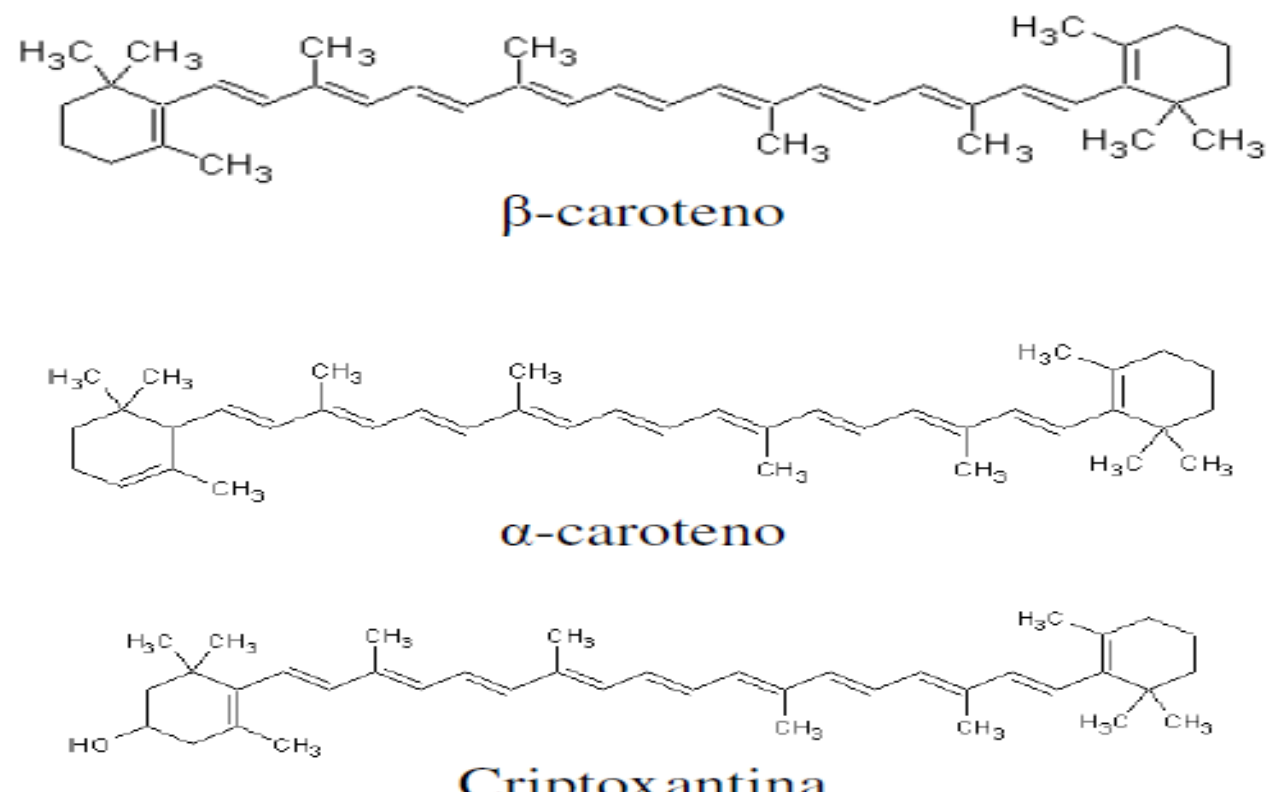

\section{Criptoxantina}

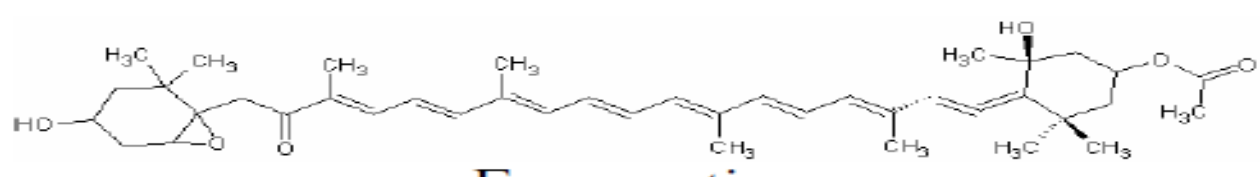

Fucoxantina

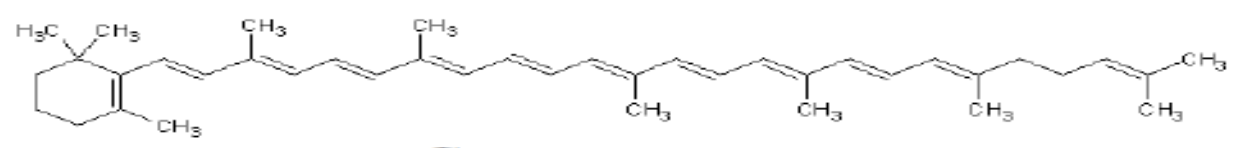

\section{Gama-caroteno}
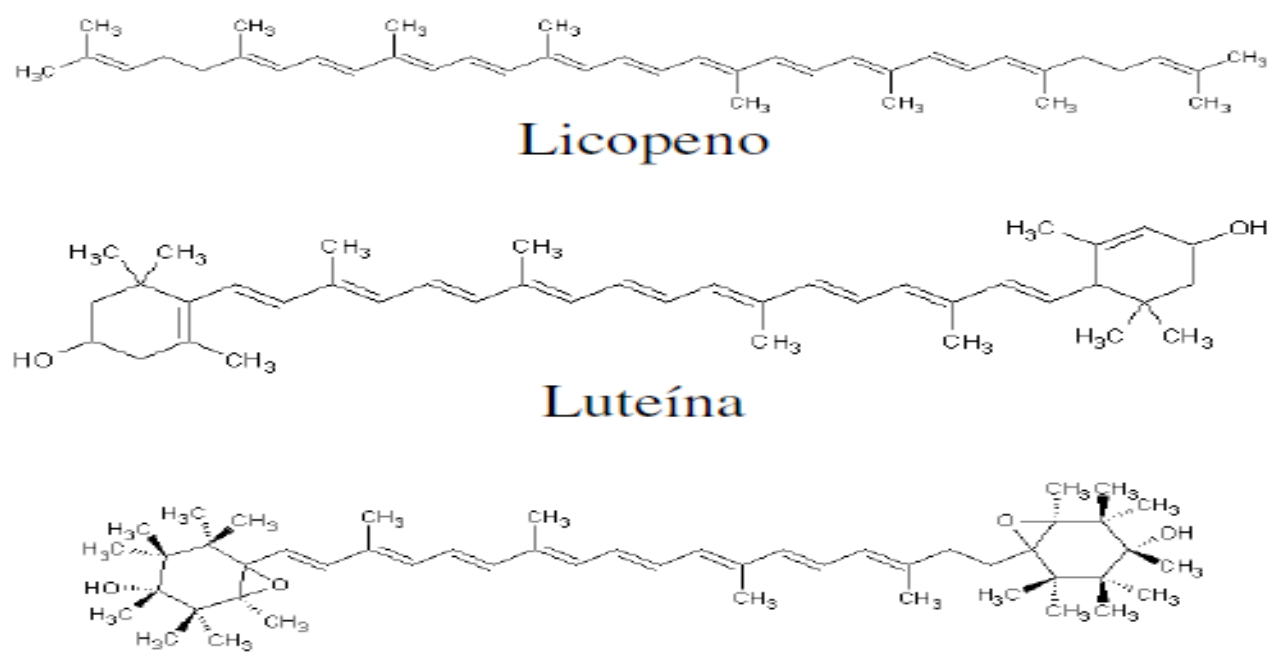

Violaxantina

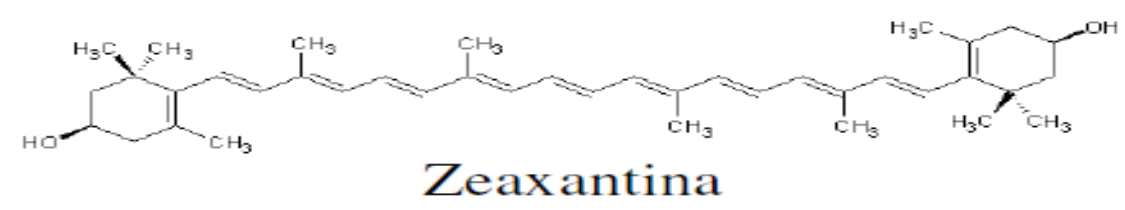

Figura 1 - Estrutura química de nove carotenóides (AMBRÓSIO et al., 2006). 
A biofortificação da mandioca apresenta várias vantagens, mas também algumas dificuldades. Como vantagens podem-se citar a alta cobertura populacional, o fato de não modificar os hábitos alimentares e de apresentar baixo risco de toxicidade. Como dificuldades têm-se a possibilidade do consumo exagerado do alimento, a sua distribuição e o preço (ZANCUL, 2004).

Para os países em desenvolvimento, devem-se levar em consideração as dificuldades existentes no acesso da população aos alimentos fortificados industrializados. A recente introdução da biofortificação pode, nesses casos, representar um novo e importante papel, na redução da deficiência de micronutrientes no Mundo (McCLAFFERTY \& RUSSELL, 2002).

McCLAFFERTY \& RUSSELL (2002) também afirmaram que a biofortificação é uma estratégia que vem sendo utilizada em programas de melhoramento genético e que pode ser uma importante ferramenta no combate à deficiência da vitamina $\mathrm{A}$, com a maior vantagem de não modificar o comportamento de produtores e consumidores.

Segundo ZANCUL (2004) em Uganda, país onde a batata doce é o principal alimento de $90 \%$ das famílias das regiões mais pobres, foi desenvolvida uma variedade de batata doce enriquecida por carotenóides, que cresce rápido em qualquer tipo de solo e que pode ser de grande importância no combate à deficiência de vitamina A no país.

\subsubsection{Proteína}

A mandioca é uma espécie muito utilizada na alimentação humana e animal em países da América Latina, Ásia e África. Como fonte calórica para a nutrição humana, a raiz de reserva da mandioca é classificada em quarto lugar, após arroz, cana-de-açúcar e milho (PUONTI-KAERLAS, 1998).

A raiz de reserva de mandioca é um órgão com alto conteúdo de carboidratos (85\%) e baixo conteúdo de proteínas (1-2\%) (COCK, 1985). Este órgão é diferenciado a partir da raiz adventícia que se origina de manivas-sementes do caule utilizadas na propagação vegetativa da espécie. A raiz de reserva é formada a partir do aumento em diâmetro da raiz adventícia resultante do crescimento secundário e do processo de diferenciação celular que dá origem ao tecido especializado na função de armazenamento, principalmente de amido.

Análises comparativas de extratos protéicos de raízes de reserva e adventícias separados em géis bi-dimensionais mostraram uma grande variabilidade na complexidade dos padrões de proteínas dos dois tipos de raízes (CABRAL \& CARVALHO, 2001). A população proteica apresentou massa molecular de 14 a 100 
kDa e distribuição em valores de $\mathrm{pl}$ de 4.0 a 6.5. As análises dos padrões protéicos indicaram que as raízes adventícias apresentaram um perfil mais simples relacionado ao crescimento primário de raízes, enquanto nas raízes de reserva foi observada uma maior complexidade atribuída ao crescimento secundário e a acumulação de amido. Os resultados destas análises possibilitaram o estabelecimento de cinco classes proteicas que podem estar associadas à formação das raízes de reserva (CABRAL \& CARVALHO, 2001).

\subsection{4. Ácido cianídrico}

Uma das características das plantas de mandioca é a presença de um glicosídeo (tipo de açúcar) potencialmente hidrolisável liberando cianeto $\left(\mathrm{HCN}^{-}\right)$. A hidrólise não é evidente e só ocorre naturalmente na presença de uma enzima da própria planta. Se a hidrólise não ocorre, o glicosídeo, tecnicamente denominado linamarina, é estável e inócuo. Esse processo denominado cianogênese, isto é, a capacidade de produzir ácido cianídrico ou íon cianeto $(\mathrm{HCN})$, sob circunstâncias particulares, é observada em várias espécies de vegetais. Atualmente são conhecidas 2650 plantas chamadas cianogênicas provenientes de 550 gêneros e 130 famílias. Fazem parte desse grupo maçã, aveia, trigo, centeio, cana-de-açúcar, entre outras. A formação de ácido cianídrico ou cianeto se dá através da degradação desses glicosídeos específicos das plantas no momento em que são processadas, ou seja, moídas, amassadas, cortadas, etc (CAGNON et al., 2002).

No caso da mandioca, seu uso como alimento está sujeito à presença desses glicosídeos cianogênicos, potencialmente tóxicos. Eles são, na maior parte, removidos durante o processamento (cozimento, moagem seguida de torrefação, entre outros) da mandioca, porém em vários alimentos esses resíduos permanecem, comprometendo a sua comercialização com os países europeus e asiáticos. Efetivamente, pela forma de preparo da mandioca no Brasil, todos os produtos são seguros para alimentação humana (CAGNON et al., 2002).

Quando a concentração de HCN nas raízes frescas de um acesso de mandioca excede a 100 ppm, o mesmo é considerado tóxico para o consumo humano in natura e necessita ser processado antes do consumo, a fim de eliminar o excesso de HCN. Esses acessos são chamados de bravos e são consumidos principalmente na forma de farinha, amido, glicose, entre outros. Por sua vez os acessos que apresentam menos de 100 ppm de HCN nas raízes frescas, são conhecidos como mandiocas de mesa, mansas, macaxeiras, aipins entre outras e além de poderem ser processados podem ser consumidos in natura (cozidos, fritos, entre outros). Ou seja, as mandiocas mansas se 
destinam tanto ao consumo in natura quanto a indústria e as mandiocas bravas necessariamente se destinam a indústria. Atualmente, os acessos de mandioca são classificados como de mesa ou de indústria em razão de seu destino e não somente em razão do teor de $\mathrm{HCN}$ em suas raízes, uma vez que acessos de mandioca mansa podem ser utilizados também na indústria em especial de farinha e fécula (FUKUDA et al., 2006).

A mandioca (Manihot esculenta Crantz) é a cultura mais conhecida por acumular glicosídeos cianogênicos. Apesar de atrair a atenção de alguns grupos de pesquisa, poucos resultados foram definitivamente estabelecidos sobre o acúmulo desses glicosídeos cianogênicos e seus efeitos (CONN, 1994). A mandioca acumula dois glicosídeos potencialmente tóxicos em todas as partes da planta, a linamarina 1 e a lotaustralina 2 (razão de aproximadamente 93:7) que são $\beta$-glicosídeos de acetonacianidrina e etil-metil-cetona-cianidrina respectivamente (WOOD, 1966). De acordo com MACMAHON et al. (1995), os glicosídeos cianogênicos (HCN) da mandioca são compostos por 95\% de linamarina e 5\% de lotustralina, distribuídos de forma variável nas diferentes partes da planta, entretanto, a parte comestível das raízes contém menores níveis de $\mathrm{HCN}$ do que as folhas, o caule e o córtex das raízes. BOLHUIS (1954) afirmou que esses cianoglicosídeos distribuem-se por toda a planta, porém a concentração varia substancialmente entre variedades. Além destes, a planta possui a enzima linamarase ( $\beta$-glicosidase), presente principalmente na casca da mandioca, que é a responsável pela hidrólise dos compostos cianogênicos quando a planta ou raiz sofre algum tipo de lesão, resultando na liberação de cianeto (HCN).

A biosíntese da linamarina e lotustralina realiza-se principalmente nas folhas jovens e pecíolos e, respectivamente, a partir dos aminoácidos valina e isoleucina. Em seguida, os compostos são translocados, via floema, para as raízes (BOKANGA, 1994), sendo o conteúdo cianogênico das raízes determinado principalmente pela característica varietal, porém pode variar de acordo com as condições ambientais, práticas culturais e estado fisiológico da planta (MCMAHON et al., 1995). Porém, o componente genético é um dos principais fatores determinantes do $\mathrm{HCN}$ e o que apresenta a maior estabilidade, com isso, é possível classificar as variedades de mandioca quanto à sua toxicidade (LORENZI \& DIAS, 1993). 


\section{REFERÊNCIAS BIBLIOGRÁFICAS}

ALBUQUERQUE, J.A.A.; SEDIYAMA, T.; SILVA, A.A.; SEDIYAM, C.S.; ALVES, J.M.A.; NETO, F.A. Caracterização morfológica e agronômica de clones elite de mandioca cultivadas no Estado de Roraima. Revista Brasileira de Ciência Agrárias, Recife, v. 4, p. 388-394, 2009.

ALVES, A. A.C. Cassava Botany and Physiology. In: HILLOCKS, R. J.; THRESH, J. M.; BELlOTTI, A. (Eds.). Cassava: biology, production and utilization. CABI, p. 67-71, 2002.

AGUIAR, J.L.P.; BARRETO, B.; SOUSA, T.C.; FIALHO, J.F. Cadeia produtiva da mandioca no Distrito Federal: Caracterização do consumidor final. In: CONGRESSO BRASILEIRO DE MANDIOCA, 11. Resumos... Campo Grande: Embrapa Agropecuária Oeste. 2005.

ALLEM, A. C. Cassava: biology, production and utilization. In: HILLOCKS, R.J.; THRESH, J.M.; BELLOTII, A.C. (Eds.) The origins and taxonomy of cassava. Reino Unido: Natural Resources Institute, University of Greenwich, 2002. p. 1-16.

ALLEM, A. C.; GOEDERT, C. O. Formação da base genética e manejo dos recursos genéticos de mandioca: o caso do Brasil. In: HERSHEY, C. (Ed.). Mejoramiento genético de la yuca em América Latina. Cali: CIAT, 1991, p.125-158.

AMBRÓSIO, C.L.B.; CAMPOS, F.A.C.S.; FARO, Z.P. Carotenóides como alternativa contra a hipovitaminose A. Revista de Nutrição, Campinas, v. 19, n. 2, p. 233-243, 2006.

BAUEMFEIND, J. C. Carotenoid vitamin A precursors and analogs in foods and feeds. Journal of Agricultural and Food Chemistry; n. 20: p. 456-473, 1972.

BILIADERIS, C.G. The structure and interactions of starch with food. Canadian Journal of Physiology and Pharmacology, n. 69: p. 60-78, 1991.

BYRNE, D. Breeding cassava. In: JANICK, J. (Ed.). Plant breeding reviews II. AVI, Westpoint, U.S.A. p.73-134, 1984.

BOKANGA, M. Distribution of cyanogenic potencial in cassava germplasm. Acta Horticulturae. n. 375, p. 117-123, 1994.

BOLHUIS, G.G. The toxicity of cassava roots. Netherlands Journal of Agricultural Science, Wageningen, v. 2, n. 3, p. 176-185, 1954.

BONIERBALE, M.; IGLESIAS, C.; KAWANO, K. Genetic resources management of cassava at CIAT. In: International Workshop on Genetic Resources: Root and Tuber Crops, 1995, Tsukuba. Proceeding...Tsukuba: Maff, p. 39-52, 1995. 
BORÉM, A. Melhoramento de plantas. Viçosa: UFV, 1997. 547p.

BRETTING, P.K.; WIDRLECHENER, M.P. Genetic markers and horticultural germplasm management. HortScience, Alexandria, v. 30, n. 7. p. 1349-1355, 1995.

CABRAL G. B.; CARVALHO, L. J. C. B. Analysis of proteins associated wiht storage root formation in cassava using two-dimensional gel eletrophoresis. Revista Brasileira de Fisiologia Vegetal, 13:41-48, 2001.

CAGNON, J.R.; CEREDA, M.P.; PANTAROTTO, S. Glicosídeos cianogênicos da mandioca: biossíntese, distribuição, destoxificação e métodos de dosagem. In: CEREDA, M.P. (Ed.). Agricultura: tuberosas amiláceas Latino Americanas. São Paulo: Fundação Cargill, 2002. p. 83-99. (Culturas de Tuberosas Amiláceas Latino Americanas, v.2).

CARVALHO, C.R.L. Determinação de isômeros geométricos de alguns carotenoides provitamínicos A por cromatografia líquida de alta eficiência. 1996.

127 f. Dissertação (Mestrado em Química) - Instituto de Química da Universidade Estadual de Campinas, Campinas-SP. 1996.

CARVALHO, L. J. C. B.; CABRAL, G. B.; CAMPOS, L. Raiz de reserva de mandioca: um sistema biológico de múltipla utilidade. Brasília, DF: Embrapa Recursos Genéticos e Biotecnologia, 2000. 16p. (Embrapa Recursos Genéticos e Biotecnologia, 44).

CARVAlHO, P. R. N.; SILVA, M. G. da; CARVAlHO, C. R. L.; VAlle, T. L.; CASTRO, J. V. de; FELTRAN, J. C. Cor e carotenóides provitamínicos em raízes de diferentes clones de mandioca (Manihot esculenta Crantz). In: CONGRESSO BRASILEIRO DE MANDIOCA, 11. Resumos... Campo Grande: Embrapa Agropecuária Oeste. 2005.

CEBAllos, H. Anual Reporter - HarvestPlus. Centro Internacional de Agricultura Tropical. Cali, Colombia: (CIAT). 2005.

CEBAllos, H.; IGLESIAS, C.A.; PÉREZ, J.C.; DIXON, A.G.O. Cassava breeding: opportunities and challenges. Plant Molecular Biology, v.56, p.503-516, 2004.

CHÁVEZ, A. L.; BEDOYA, J. M. C.; IGLESIAS, C.; CEBALlOS, H.; ROCA, W. Exploring the genetic potential to improve micronutrientes contente of cassava. Improving Human Nutrition Through Agriculture, Los Baños, Philipines. 1999. CLEMENT, C.R.; CRISTO-ARAUJO, M.; EECKENBRUGGE, G.C.; PEREIRA, A.A.; PICANÇO-RODRIGUES, D. Origin and domestication of native Amazonian crops. Diversity 2: p. 72-106, 2010. 
COCK, J. H. Cassava: a basic energy source in the tropics. In "Cassava: Research, production and utilization". COCK, J. H.; REYES, J. A. (Eds.). UNDT CIAT. Cali, Colombia. 1985.

CONN, E. E. "Cyanogenesis- A personal perpective". Acta Horticulturae, 375, p. 3143, 1994.

DAIUTO, E. R.; CEREDA, M. P.; CARVAlHO, L. J. C. B. Características e propriedades do amido extraído de camadas do tecido da raiz de mandioca. Brazilian Journal Of Food Technology, v. 5, p. 217-223, 2002.

DOMINGUEZ, C. E.; CEBAllos, L. F.; FUENTES, C. Morfologia de la planta de yuca. In: DOMINGUEZ, C. E. (Ed.). Yuca: investigacion, produción. Cali: PNUD/CIAT, 1982. p. 29-49.

FAOSTAT. Faostat database. Disponível em: <www.faostat.org>. Acesso em 30 de jul. 2013.

FREY, K.J. Plant breeding perspectives for the 1990s. In: STALKER, H.T.; MURPHY, J.P. (Eds.). Plant Breeding in the 1990s. Wallington: CABI International, Wallington, 1992. p. 1-13.

FUKUDA, W. M. G. Hibridação em mandioca. In: BORÉM, A. (Ed.) Hibridação artificial de Plantas. Viçosa: UFV, 1999. p. 343-356.

FUKUDA, W. M. G. Mandioca: estratégias para um programa de melhoramento genético. Cruz das Almas: Embrapa-CNPMF, 1996. 35p. (Embrapa-CNPMF. Documentos, 71).

FUKUDA, W. M. G. Melhoramento de mandioca no Brasil. In: REUNIÓN PANAMERICANA DE FITOMEJORADORES DE YUCA, 2, 1992, Cali. Memórias... Cali: CIAT, 1992. p. 15-31.

FUKUDA, W. M. G. Técnica de polinização manual de mandioca. Cruz das Almas: Embrapa-CNPMF, 1980. 3p. (Embrapa-CNPMF. Miscelânea, 1).

FUKUDA, W. M. G.; GUEVARA, C.L. Descritores morfológicos e agronômicos para a caracterização de mandioca (Manihot esculenta Crantz). Cruz das Almas: Embrapa Mandioca e Fruticultura Tropical, 38 f. 1998.

FUKUDA, W. M. G. e IGLESIAS, C. Melhoramento genético. In: SOUZA, L. S.; FARIAS, A. R.; MATTOS, P. L. P.; FUKUDA, W. M. G. (Eds.). Aspectos socioeconómicos e agronómicos da mandioca. Cruz das Almas: Embrapa Mandioca e Fruticultura Tropical, 2006. p. 325-363. 
FUKUDA, W. M. G., PORTO, M. C. M. A mandioca no Brasil. In: HERSHEY, C. H. (Ed.). Mejoramiento genetic de la yucca en América Latina. Cali: Ciat, 1991. p. 1542 .

FUKUDA, W. M. G.; SILVA, S. O.; IGLESIAS, C. Cassava breeding. Crop Breeding and Applied Biotechnology, v.2, n.4, p. 617-638, 2002.

GALERA, J. M. S. V.; VALLE, T. L. Estruturação genética do germoplasma de mandioca através de informação comparativas entre estudos biológicos e antropológicos - resultados preliminares. Raízes e Amidos Tropicais. v.3, n.1, 2007.

HALLAUER, A. R. Use of genetic variation for breeding populations in cross pollinated species. In: STALKER, H.T.; MURPHY, J.P. (Eds.) Plant breeding in the 1990s. Wallinfor: CAB Intenational, 1992, p. 37-67.

HERSHEY, C. H.; AMAYA, A. Genética, citogenética, estrutura floral e técnicas de hibridación de la yucca. In: SOMÍNGUEZ, C. E. (Ed.). Yuca: investigación, production y utilización. Cali: PNUD/CIAT, 1982, p. 113-126.

IBGE. Disponível <http://www.ibge.gov.br>. Acesso em: 11 mai. 2014.

KAWANO, K. Mejoramiento genético de yucca para productividad. In: DOMÍNGUEZ, C. E. (Ed.). Yuca: Investigación, production y utilización. Cali: Pnud/Ciat, 1982. p. 91112.

KAWANO, K.; AMAYA, A.; RIOS, M. Factors affecting efficiency of hybridization and selecyion in cassava. Crop Science, Madison, v.17, p. 373-376, 1978.

KAWUKI, R.S.; FERGUSON, M.; LABUSCHAGNE, M.T.; HERSELMAN, L.; ORONE, J.; RALIMANANA, I.; BIDIAKA, M.; LUKOMBO, S.; KANYANGE, M.C.; GASHAKA, G.; MKAMILO, G.; GETHI, J.; OBIERO, H. Variation in qualitative and quantitative traits of cassava germplasm from selected national breeding programmes in sub-Saharan Africa. Field Crops Research, Netherlands, v. 122, p. 151-156, 2011.

LORENZI, J. O. Mandioca. CATI: Campinas, 116 p., 2003. (Boletim Técnico, 245).

LORENZI, J. O.; DIAS, C. A. C. Cultura da mandioca.Campinas, n. 211, 41 p., 1993. (Boletim Técnico, 211).

LORENZI, J.O.; VALLE, T.L. IAC 576: A variedade de mandioca de mesa mais cultivada no Estado de São Paulo. Campinas: IAC, 2002. 4 p.

LÉON, J. Origin, evolution, and early dispersal of root and tuber crops. In: SYMPOSRTM OF THE MTERNATIONAL SOCIETY FOR TROPICAL ROOTS CROPS, 1977, Cali, Resumos... Cali: International Society for Troical Roots Crops, 1977. p. 20-36. 
MCMAHON, J. M.; WHITE, W. L. B.; SAYRE, R. T. Cyanogenesis in cassava (Manihot esculenta Crantz). Journal of Experimental Botany, Oxford, v. 46, n. 288, p. 731-741, 1995.

McCLAFFERTY B.; RUSSELL, N. Plant breeding to combat micronutrient deficiency. International Food Policy Research Institute, Washington, 2002.

MENDES, R. A. Melhoramento genético da mandioca no Centro Nacional de Pesquisa de Mandioca e Fruticultura Tropical. In: CONGRESSO BRASILEIRO DE MANDIOCA, 2., 1982, Vitória. Anais...Vitória: SBM. p.142-145, 1982.

MORAES-DALlAQUA, M. A. de; CORAL, D. J. Morfo-anatomia. In: CEREDA, M. P. (Coord.). Agricultura: tuberosas amiláceas latino-americanas. São Paulo: Fundação Cargill, 2002. 540p. (Série: culturas de tuberosas amiláceas latino-americanas, 2).

MURRIETA, R. S. S. Dialética do sabor: alimentação, ecologia e vida cotidiana em comunidades ribeirinhas da Ilha de Ituqui, Baixo Amazonas, Pará. Revista de Antropologia, São Paulo, v. 44, n. 2, p. 39-88, 2001.

NASSAR, N.M.A. Cassava, Manihot esculenta Crantz and wild relatives: Their relationships and evolution. Genetic Resources and Crop Evolution, Netherlands, v. 48, p. 429-436, 2001.

NORMANHA, E. S. Cassava breeding work at the São Paulo State. In: Encontro De Engenheiros Agrônomos do Estado de São Paulo, 1., 1970, São Paulo-Campinas. Trabalhos... Campinas: Instituto Agronômico, 1970. p. 40-47.

OJULONG, H.; LABUSCHANGNE, M.T.; FREGENE, M.; HERSELMAN, L. A cassava clonal evalution trial based on a new cassava breeding scheme. Euphytica, Wageningen, v. 160, p. 119-129, 2008.

OLSEN, K.M. SNPs, SSRs and inferences on cassava's origin. Plant Molecular Biology, New York, v. 56, p. 517-526, 2004.

OLSEN, K.M.; SCHALL, B.A. Evidence on the origin of cassava: Phylogeography of Manihot esculenta. Proceeding of the National Academy of Sciences, Washington, v. 96, p. 5586-5591, 1999.

PEREIRA, A. V. Utilização de análise multivariada na caracterização de germoplasma de mandioca (Manihot esculenta Crantz). 1989. 180 f. Tese (Doutorado em Melhoramento Genético). Escola Superior de Agricultura Luiz de Queiroz, Universidade de São Paulo, Piracicaba, 1989.

PRIGENT, S. Les noveaux produits, leur intérê et leur mode d'utilisation. Information dietétique, Paris, n. 2, p. 33-37, 1992. 
PUONTI-KAERLAS, J. Biotechnology and Genetic Engineering Reviews. (In: TOMBS, M.P. (Ed.), Cassava biotechology. Intercept L, td, Andover, Hampshire, UK. n. 15: p. 329-364, 1998.

RAMALHO, A.; SAUNDERS, C.; ACCIOLY, E. Novos grupos de risco para a deficiência De vitamina A. 2002. Disponível em: <http://www.comuniquese.com.br/produtos/saladeimprensa/premiowyeth/artigo_n ovos_grupos_de_riscos_para_deficiencia_de_vitamina_a.pdf.>. Acesso em: $13 \mathrm{dez}$ 2013.

REICHEL-DOLMANTOFF, G. Momil a primative sequence the sinu Valle, Colombia. American Antiquity, v. 22, p. 226-234, 1957.

RENOVOIZE, B. S. The área of origino of Manihot esculenta as a crop plant a review of the evidence. Economic Botany, v.26, p.352-360, 1973.

RIMOLDI,F. VIDIGAL FILHO, P.S.; KVITSCHAL, M.V.; GONÇALVES-VIDIGAL, M.C.; PRIOLI, A.J.; PRIOLI, S.M.A.P.; COSTA, T.R. Genetic divergence in sweet cassava cultivars using morphological agronomic traits and RAPD molecular markers. Brazilian Archives of Biology and Techonology, Curitiba, v.53, p. 1477-1486, 2010. ROA, A. C.; MAYA, M. M.; DUQUE, M. C.; THOME, J.; AllEM, A. C.; BONIERBALE, C.; M. W. AFLP. Analysis of relatioships among cassava and other Manihotis species. Theoretical and Applied Genetics, v.95, p.741-750, 1997.

ROA, A. C.; CHAVARRIAGA, P.; DUQUE, M. C.; MAYA, M. M.; BONIERBALE, M. W.; IGLESIAS, C.; THOME, J. Cross-specific amplification of cassava (Manihot esculenta) (Euphorfiaceae) microsatelites: allelic polymorphism and degree of relationship. American Journal of Botany, v. 87, p.1647-1655, 2000.

ROGERS, D. J.; APPAN, S. G. Manihot and Manihotoides (Euphorbiacere). Flora Neotropica Monograph, New York, v.13, p.1-272, 1973.

SARMENTO, S.B.S. Caracterização da fécula de mandioca (Manihot esculenta C.) no período de colheita de cultivares de uso industrial. 1997. 162 f. Tese (Doutorado em Bromatologia). Universidade de São Paulo, Faculdade de Ciências Farmacêuticas, São Paulo, 1997.

SILVA, K. N. ; VIEIRA, E. A.; FIALHO, J. de F.; CARVALHO, L. J. C. B.; SILVA, M. S. Potencial agronômico e teor de carotenoides em raízes de reserva de mandioca. Ciência Rural (UFSM. Impresso), v. 44, p. 1348-1354, 2014.

SIVIERO, A.; SCHOTT, B. Caracterização botanica e agronomica da coleção de mandioca da Embrapa Acre. Revista Raízes e Amidos Tropicais, Botucatu, v. 7, p. 3141, 2011. 
SOUZA, L.S.; FIALHO, J.F. Sistema de produção de mandioca para a região do cerrado. Cruz da Almas: CNPMF, 2003. 61f.

VAlle, T. L. Cruzamentos dialélicos em mandioca (Manihot esculenta Crantz). 1990. 180 f. Tese (Doutorado em Melhoramento Genético). Escola Superior de Agricultura Luiz de Queiroz, Universidade de São Paulo, Piracicaba, 1990.

VIEIRA, E.A. Divergência genética entre acessos açucarados e não açucarados de mandioca. Pesquisa Agropecuária Brasileira, Brasília, v. 43, n. 12, p. 1107-1715, 2008.

VIEIRA, E.A.; FIALHO, J. de F.; FALEIRO, F. G. ; BELLON, G.;SILVA, M. S. Caracterização molecular de acessos de mandioca biofortificados com potencial de uso no melhoramento genético. Revista Ciência Agronômica (UFC. Online), v. 42, p. 457 463, 2011a.

VIEIRA, E. A.; FIALHO, J. F.; SILVA, M.S. Recursos genéticos e melhoramento da mandioca In: FIALHO, J. F.; VIEIRA, E. A. (Eds.). Mandioca no Cerrado: orientações técnicas. Brasília-DF: Embrapa Cerrados, v.1, p. 25-35, 2011 b.

VILPOUX, O.; CEREDA, M.P. Processamento de raízes e tubérculos para uso culinário: minimamente processadas, vácuo, pré-cozidas congeladas e fritas (frenchfries). In: Série culturas de tuberosas amiláceas latino americanas, 3., 2002, Fundação Cargill, 2002. p. 81-109.

WOOD, T. "The isolation, properties, and enzymic breakdown of linamarin from cassava". Journal of the Science of Food and Agriculture. 1996, v. 17, p.85-87.

ZANCUL M.S. Fortificação de alimentos com ferro e vitamina A. Medicina, Ribeirão Preto, v.37, p. 45-50, 2004.

ZEHMTMER, L. Estudo sobre algumas variedades de mandiocas brasileiras. Rio de Janeiro: Imprensa Inglesa, 1919. 112p. 
CAPÍTULO 1. CARACTERES MORFOLÓGICOS DE CLONES ELITE DE MANDIOCA DE MESA DE POLPA AMARELADA BIOFORTIFICADA CHAPTER 1. MORPHOLOGICAL CHARACTERS IN SWEET CASSAVA ELITE CLONES WITH BIOFORTIFIED YELLOWISH PULP 


\section{RESUMO}

A mandioca (Manihot esculenta Crantz) é uma das culturas mais importantes na alimentação humana dos trópicos e fonte de renda estimada para 500 milhões de pessoas, principalmente para populações carentes. Este trabalho teve como objetivo caracterizar, por meio de descritores morfológicos, clones elite de mandioca de mesa de polpa amarelada biofortificada em processo de seleção pelo Programa de Melhoramento de Mandioca realizado na Embrapa Cerrados. Foram caracterizados 13 clones de mandioca, em comparação com a variedade testemunha IAC 576-70, em experimentos conduzidos na Embrapa Cerrados durante duas safras. Foram obtidos 40 descritores morfológicos qualitativos para cada clone. Com base na distribuição de frequência dos genótipos nas diferentes classes fenotípicas, foi calculado o coeficiente de entropia para cada descritor. A matriz de dissimilaridade genética entre os clones foi calculada com base no coeficiente de coincidência simples das classes fenotípicas e, a partir dessa matriz, foi realizada a análise de agrupamento via dendrograma. Houve diferenças morfológicas entre os clones, demostrando que nenhum par de genótipos apresentou $100 \%$ de similaridade. Não houve influencia do fator ano/safra na expressão fenotípica dos caracteres aferidos. Com base no coeficiente cofenético, verificou-se elevado ajuste entre a representação gráfica via dendrograma e a matriz de dissimilaridade genética. Entre os caracteres aferidos, aqueles que apresentaram maior entropia foi à coloração da epiderme externa, forma do lóbulo central da folha e cor do córtex da raiz. Entre os clones avaliados, identificaram-se alguns com potencial para recomendação para cultivo comercial conforme seus caracteres morfológicos desejáveis do ponto de vista agronômico.

Palavras-chaves: Manihot esculenta Crantz, melhorameto genético, caracteres morfológicos, biofortificação, recursos genéticos 


\begin{abstract}
Cassava (Manihot esculenta Crantz) is one of the most important crops in food of the tropics and source of income estimated 500 million people, especially for needy populations. The research was characterize by morphological, clones elite biofortified of pulp yellowish edible cassava descriptors in the process of selection for cassava improvement program carried out at Embrapa Cerrado. They were characterized 13 cassava clones, compared with the control variety IAC 576-70, in experiments conducted at Embrapa Cerrado during two crop seasons. To evaluate the morphological characteristics were obtained 40 qualitative descriptors for each clone. Based on the frequency distribution of the different genotypes phenotypic classes, were calculated the entropy coefficient for each descriptor. The matrix of genetic dissimilarity between the clones was calculated based on the coincidence factor of phenotypic classes, and from this matrix, was carried out via cluster analysis dendrogram. There was morphological differences among clones, showing that no two genotypes showed $100 \%$ similarity. There was no influence of year / crop factor phenotypic expression of measured characters. Based on cofenetic coefficient was found high fit between the graphical representation via dendrogram and the genetic dissimilarity matrix. Among the measured characters, those who highest entropy were the color of the extern epiderm of the central lobe leaf shape and color of the root cortex. Among clones, identified are some potential for clones with recommendation for commercial cultivation according the desirable morphological characters from an agricultural point of view.
\end{abstract}

Key words: Manihot esculenta Crantz, genetic breeding, characterize morphological, biofortified, genetic resources 


\subsection{INTRODUÇÃO}

A mandioca (Manihot esculenta Crantz) é uma das culturas mais importantes na alimentação humana dos trópicos, principalmente para populações de baixa renda. A produção mundial da mandioca foi estimada pela FAO (2013) em 257 milhões de toneladas de raízes e segundo o IBGE (2013), a produção nacional dessa cultura foi de 23 milhões de toneladas em 2012. A principal contribuição social da mandioca reside na alimentação de 700 milhões de pessoas que consomem de 200 a 1.000 calorias diárias, sendo a mandioca a sua principal fonte de carboidratos.

A mandioca é muito importante em países em desenvolvimento, principalmente em função da sua rusticidade e da capacidade que apresenta de produzir razoavelmente bem em condições em que outras culturas sequer sobreviveriam. Tal habilidade advém de a espécie ser tolerante a solos ácidos e à seca, e ao mesmo tempo oferecer flexibilidade de colheita (CEBALLOS et al., 2004).

A região do Cerrado que ocupa em torno de $23 \%$ do território brasileiro (RATTER et al., 1997; KLINK \& MACHADO, 2005) apresenta características de clima e de solo favoráveis ao cultivo de mandioca (FIALHO et al., 2013). Apesar de todo o potencial da região do Cerrado brasileiro para o cultivo de mandioca, atualmente apenas $10 \%$ da área plantada e $10 \%$ da produção nacional da mandioca estão localizadas na Região, com

uma produtividade média de apenas $13 \mathrm{t} \mathrm{ha}^{-1}$ em uma área colhida de 242.528 ha (IBGE, 2013).

A baixa produtividade de raízes de mandioca na região pode ser explicada pelo baixo profissionalismo dos produtores, que normalmente não seguem as recomendações para o cultivo por desconhecimento ou por dificuldades financeiras. Além disso, para aumentar a produtividade da mandioca na região são necessárias ações de pesquisa e desenvolvimento em sistemas de produção e na seleção de variedades adaptadas às condições locais, além de trabalhos sistemáticos de transferência de tecnologia.

O cultivo de mandioca de mesa apresenta potencial para expansão na região do Cerrado, em especial nos cinturões verdes das grandes cidades, em razão da elevada rentabilidade da atividade. A carência de variedades adaptadas, produtivas e de alta qualidade nutricional evidencia a necessidade de avaliação de constituições genéticas com elevado potencial agronômico e com a coloração das raízes amarelas (biofortificadas) adaptadas à região do Cerrado.

A espécie apresenta potencial para ser uma excelente fonte de carotenóides na alimentação humana, em especial de $\beta$-caroteno, precursor da vitamina $\mathrm{A}$, o qual é 
encontrado em grande quantidade nas raízes de coloração amarela (IGLESIAS et al., 1997; MEZZETE et al., 2009). Nesse contexto, a possibilidade da mandioca não ser apenas fonte de calorias para a população, mas também uma fonte de vitamina A é uma das formas de melhorar a nutrição da população e ao mesmo tempo agregar valor a variedades destinadas ao consumo humano (WELSH \& GRAHAM, 2002).

A caracterização morfológica por meio de descritores categóricos é importante para a caracterização e diferenciação dos genótipos para fins de proteção de cultivares e também para estudos de variabilidade genética, possibilitando assim o desenvolvimento e a disponibilização de genótipos superiores de mandioca de mesa para os produtores e consumidores. Os descritores morfológicos são de fácil aferição, menor custo de avaliação e menos influenciados pelo ambiente. Dessa forma, neste trabalho, objetivouse caracterizar por meio de descritores morfológicos clones elite de mandioca de mesa amarelas biofortificadas selecionadas em condições do Cerrado do Brasil Central.

\subsection{MATERIAL E MÉTODOS}

O trabalho foi conduzido no campo experimental e no Laboratório de Raízes e Tubérculos da Embrapa Cerrados (CPAC), em Planaltina-DF, entre outubro de 2010 e outubro de 2011 e entre novembro de 2011 e novembro de 2012.

Para a realização do estudo foram caracterizados treze clones elite de mandioca de mesa (clone 26/08, clone 83/08, clone 90/08, clone 91/08, clone 94/08, clone 215/08, clone 246/08, clone 259/08, clone 272/08, clone 273/08, clone 446/08, clone 450/08 e clone 497/08) selecionados para as condições do Cerrado (Tabela 1), sendo utilizada como testemunha a variedade de mandioca de mesa IAC 576-70, conhecida popularmente na região do Cerrado como Japonesinha, que no Banco de Germoplasma de Mandioca do Cerrado (BGMC) está identificada como BGMC 753 e que é indicada para o cultivo na região (FIALHO et al., 2009). 
Tabela 1. Relação dos clones de mandioca do Programa de Melhoramento de Mandioca do Cerrado avaliados com respectivos códigos, genealogia e identificação da testemunha com respectivo código do Banco de Germoplasma de mandioca do Cerrado (BGMC). UnB/ Embrapa Cerrados, Brasília, DF, 2015.

\begin{tabular}{ccc}
\hline Ordem & Clones & Genealogia dos clones \\
\hline 1 & $26 / 08$ & BGMC 751 X BGMC 753 \\
2 & $83 / 08$ & BGMC 751 X BGMC 753 \\
3 & $90 / 08$ & BGMC 751 X BGMC 753 \\
4 & $91 / 08$ & BGMC 751 X BGMC 753 \\
5 & $94 / 08$ & BGMC 751 X BGMC 753 \\
6 & $215 / 08$ & BGMC 751 X BGMC 753 \\
7 & $246 / 08$ & BGMC 751 X BGMC 753 \\
8 & $259 / 08$ & BGMC 1289 X BGMC 753 \\
9 & $272 / 08$ & BGMC 1289 X BGMC 753 \\
10 & $273 / 08$ & BGMC 1289 X BGMC753 \\
11 & $446 / 08$ & BGMC 1218 polinização aberta \\
12 & $450 / 08$ & BGMC 1218 polinização aberta \\
13 & $497 / 08$ & BGMC 1218 polinização aberta \\
14 & IAC 576-70 (BGMC 753) & - \\
\hline
\end{tabular}

O delineamento experimental utilizado foi de blocos casualizados com três repetições, sendo que cada parcela foi composta por 4 linhas de 10 plantas, com espaçamento de $0,80 \mathrm{~m}$ entre plantas e 1,20 m entre linhas. No processo de caracterização foram utilizadas as 16 plantas centrais de cada parcela, sendo que as avaliações foram feitas em 2010/2011 e repetidas em 2011/2012. A seleção do material de propagação e os práticas culturais seguiram as recomendações do sistema de produção de mandioca para a região do Cerrado (FIALHO et al., 2013, FIALHO \& VIEIRA, 2013).

Os descritores morfológicos foram avaliados no local dos experimentos nos dois anos, seguindo as instruções para a execução dos ensaios de distinguibilidade, homogeneidade e estabilidade de cultivares de mandioca (Manihot esculenta Crantz) do Ministério da Agricultura, Pecuária e Abastecimento (BRASIL, 2014) e de FUKUDA \& GUEVARA (1998). Os 40 descritores qualitativos avaliados foram: 1) coloração da folha apical; 2) pubescência do broto apical; 3) forma do lóbulo central da folha; 4) coloração do pecíolo; 5) coloração do córtex do caule; 6) coloração da epiderme externa do caule; 7) comprimento da filotaxia; 8) coloração da película da raiz; 9) coloração do córtex da raiz; 10) coloração da polpa da raiz; 11) textura da epiderme da raiz; 12) presença de floração; 13) coloração da folha desenvolvida; 14) número predominante de 
lóbulos nas folhas; 15) coloração da epiderme interna do caule; 16) hábito de crescimento do caule; 17) coloração dos ramos terminais nas plantas adultas; 18) constrições da raiz; 19) coloração da nervura central da folha; 20) posição do pecíolo; 21) proeminência das gemas foliares; 22) comprimento das estípulas; 23) margem das estípulas; 24) hábito de ramificação; 25) sinuosidade do lóbulo foliar; 26) forma da raiz; 27) tipo de planta; 28) comprimento médio da raiz; 29) diâmetro médio da raiz; 30) destaque da película da raiz; 31) destaque do córtex da raiz; 32) coloração das sépalas; 33) coloração do disco da flor; 34) coloração do estigma; 35) coloração do ovário; 36) coloração das anteras; 37) presença de estames nas flores femininas; 38) presença de pólen; 39) formação de frutos e 40) rugosidade do exocarpo do fruto. As avaliações relativas a folhas e pecíolos, caule e raízes foram efetuadas respectivamente aos seis, oito e doze meses após o plantio. Nas avaliações relacionadas às flores foram realizadas quando $50 \%$ das plantas haviam florescido. Os descritores morfológicos foram fotodocumentados e foram aferidos por dois anos.

Com base na distribuição de frequência dos clones nas diferentes classes fenotípicas, foi estimada a entropia para cada descritor por meio do coeficiente de entropia de Renyi, utilizando a fórmula:

$$
\mathrm{H}=-\sum_{i=1}^{s} p_{i} \ln p_{i}
$$

\section{Em que:}

$\mathrm{H}=$ entropia de $\mathrm{n}$ genótipos em s classes fenotípicas do descritor considerado;

$p_{i}=\mathrm{fi} / \mathrm{n}$ sendo: $\mathrm{p} 1=\mathrm{f} 1 / \mathrm{n}$ e $(\mathrm{p} 1+\mathrm{p} 2+\ldots+\mathrm{ps}=1)$ desde que $(\mathrm{n}=\mathrm{f} 1+\mathrm{f} 2+\ldots+$ fs), onde $f 1, f 2, \ldots f n$, correspondem ao número de genótipos em cada uma das classes fenotípicas (s) do descritor considerado.

O cálculo da estimativa da entropia foi realizado com o auxílio do programa Multiv v.2.3 (PILLAR, 1997). A entropia de um determinado descritor será tão maior quanto maior for o número de classes fenotípicas desse e quanto mais equilibrada for a distribuição de frequência dos acessos nas diferentes classes fenotípicas. Ou seja, para um descritor morfológico com duas classes fenotípicas, a maior entropia ocorrerá quando ambas as classes apresentarem 50\% dos genótipos avaliados.

A matriz de dissimilaridade genética entre os 14 genótipos, com base nos 22 marcadores morfológicos que evidenciaram polimorfismo, foi estimada por meio do complemento do índice de coincidência simples com auxílio do programa 
computacional Genes (CRUZ, 2001). Com base na matriz de dissimilaridade foi realizada a análise de agrupamento dos genótipos via dendrograma, utilizando como critério o método da ligação média entre grupo não ponderado, mais conhecido como UPGMA (Unweighted Pair-Group Method using Arithmetic Avarages) que utiliza as médias aritméticas (não ponderadas) das medidas de dissimilaridade. O ajuste entre a matriz de dissimilaridade e o dendrograma foi estimado pelo coeficiente de correlação cofenética (r), conforme SOKAL \& ROHLF (1962), com o auxílio do programa computacional NTSYS pc 2.1 (ROHLF, 2000).

\subsection{RESULTADOS E DISCUSSÃO}

Dentre os 40 descritores utilizados na caracterização, 22 (55\%) foram polimórficos, sendo úteis na diferenciação dos genótipos (Tabelas 1 e 2). Esta utilidade dos descritores já havia sido reportada em mandioca em trabalhos anteriores (NICK et al., 2008; ALBUQUERQUE et al., 2009; VIEIRA et al., 2011; VIEIRA et al., 2013). Os resultados obtidos evidenciaram que os descritores morfológicos de mandioca selecionados para o estudo foram eficientes na determinação de diferenças morfológicas entre os genótipos avaliados, uma vez que nenhum par de genótipos apresentou 100\% de similaridade (Figura 1). Estes resultados evidenciam a utilidade destes descritores para fins de ensaios visando à caracterização de genótipos e à proteção de cultivares de mandioca. Todos os descritores obtidos em 2010/2011 foram validados em 2011/2012 evidenciando que o fator ano/safra, não influenciou a expressão fenotípica dos caracteres aferidos.

Quanto aos caracteres que apresentaram variação entre os clones, os que exibiram o maior número de classes fenotípicas distintas foram forma do lóbulo central da folha e coloração da epiderme externa do caule ambos com cinco classes (Tabelas 2 e 3). A maioria dos caracteres apresentou duas classes fenotípicas. Os genótipos avaliados não foram diferentes entre si para 18 (45\%) caracteres, apresentando os seguintes fenótipos: coloração do pecíolo verde avermelhado, textura da epiderme da raiz rugosa, presença de floração, coloração da folha desenvolvida verde escura, hábito de crescimento do caule reto, poucas ou nenhuma constrições na raiz, coloração da nervura central da folha verde, pecíolo na posição horizontal, proeminência de gemas foliares, destaque fácil da película e do córtex da raiz, coloração do estigma branco ou creme, coloração do ovário verde, coloração das anteras amarelas, ausência de flores femininas com estames, presença de pólen, presença de frutos e exocarpo do fruto rugoso. 
Tabela 2. Caracterização morfológica dos clones de mandioca com base na coloração da folha apical (CFA), pubescência do broto apical (PBA), forma do lóbulo central da folha (FLC), coloração do córtex do caule (CCC), coloração da epiderme externa do caule (CEC), comprimento da filotaxia (CF), coloração da película da raiz (CER), coloração do córtex da raiz (CCR), coloração da polpa da raiz (CPR), número predominante de lóbulos nas folhas (NL) e coloração da epiderme interna do caule (CEpC). UnB/ Embrapa Cerrados, Brasília, DF, 2015.

\begin{tabular}{|c|c|c|c|c|c|c|c|c|c|c|c|}
\hline \multirow{2}{*}{ Clone } & \multicolumn{11}{|c|}{ Descritores morfológicos } \\
\hline & CFA & PBA & FLC & $\mathrm{CCC}$ & CEC & $\mathrm{CF}$ & CER & CCR & CPR & NL & CEpC \\
\hline IAC 576-70 & $\begin{array}{c}\text { verde } \\
\text { arroxeado }\end{array}$ & ausente & $\begin{array}{l}\text { oblongo- } \\
\text { lanceolada }\end{array}$ & $\begin{array}{l}\text { verde } \\
\text { escuro }\end{array}$ & prateado & médio & $\begin{array}{l}\text { marrom } \\
\text { escuro }\end{array}$ & branca/creme & creme & sete & $\begin{array}{c}\text { marrom } \\
\text { claro }\end{array}$ \\
\hline 26 & $\begin{array}{c}\text { verde } \\
\text { arroxeado }\end{array}$ & presente & lanceolada & verde claro & $\begin{array}{c}\text { marrom } \\
\text { claro }\end{array}$ & curto & marrom claro & amarela & amarela & sete & $\begin{array}{c}\text { marrom } \\
\text { claro }\end{array}$ \\
\hline 215 & $\begin{array}{l}\text { verde } \\
\text { arroxeado }\end{array}$ & ausente & $\begin{array}{l}\text { obovada- } \\
\text { lanceolada }\end{array}$ & verde claro & $\begin{array}{l}\text { marrom } \\
\text { escuro }\end{array}$ & médio & marrom claro & amarela & amarela & sete & $\begin{array}{c}\text { marrom } \\
\text { claro }\end{array}$ \\
\hline 246 & $\begin{array}{c}\text { verde } \\
\text { arroxeado }\end{array}$ & presente & lanceolada & verde claro & $\begin{array}{c}\text { marrom } \\
\text { claro }\end{array}$ & médio & marrom claro & amarela & amarela & sete & $\begin{array}{c}\text { marrom } \\
\text { claro }\end{array}$ \\
\hline 259 & roxo & ausente & reta/ linear & verde claro & $\begin{array}{c}\text { marrom } \\
\text { claro }\end{array}$ & médio & marrom claro & amarela & creme & sete & creme \\
\hline 272 & $\begin{array}{c}\text { verde } \\
\text { arroxeado }\end{array}$ & presente & $\begin{array}{l}\text { oblongo- } \\
\text { lanceolada }\end{array}$ & verde claro & prateado & médio & marrom claro & amarela & amarela & sete & $\begin{array}{c}\text { marrom } \\
\text { claro }\end{array}$ \\
\hline 273 & $\begin{array}{c}\text { verde } \\
\text { arroxeado }\end{array}$ & presente & $\begin{array}{l}\text { oblongo- } \\
\text { lanceolada }\end{array}$ & verde claro & $\begin{array}{c}\text { verde } \\
\text { amarelado }\end{array}$ & médio & amarela & branca/creme & amarela & sete & $\begin{array}{c}\text { marrom } \\
\text { claro }\end{array}$ \\
\hline 446 & $\begin{array}{c}\text { verde } \\
\text { arroxeado }\end{array}$ & ausente & $\begin{array}{c}\text { linear- } \\
\text { pandurada }\end{array}$ & verde claro & laranja & médio & marrom claro & branca/creme & creme & sete & $\begin{array}{c}\text { marrom } \\
\text { claro }\end{array}$ \\
\hline 450 & $\begin{array}{c}\text { verde } \\
\text { arroxeado }\end{array}$ & presente & lanceolada & verde claro & prateado & curto & marrom claro & amarela & amarela & cinco & $\begin{array}{c}\text { marrom } \\
\text { claro }\end{array}$ \\
\hline 497 & roxo & ausente & lanceolada & $\begin{array}{c}\text { verde } \\
\text { escuro }\end{array}$ & $\begin{array}{l}\text { marrom } \\
\text { escuro }\end{array}$ & médio & marrom claro & rosada & amarela & sete & $\begin{array}{c}\text { marrom } \\
\text { claro }\end{array}$ \\
\hline 83 & $\begin{array}{c}\text { verde } \\
\text { arroxeado }\end{array}$ & presente & $\begin{array}{l}\text { obovada- } \\
\text { lanceolada }\end{array}$ & verde claro & $\begin{array}{c}\text { marrom } \\
\text { claro }\end{array}$ & médio & marrom claro & amarela & amarela & cinco & $\begin{array}{c}\text { marrom } \\
\text { claro }\end{array}$ \\
\hline 90 & $\begin{array}{c}\text { verde } \\
\text { arroxeado }\end{array}$ & presente & $\begin{array}{l}\text { oblongo- } \\
\text { lanceolada }\end{array}$ & verde claro & $\begin{array}{c}\text { marrom } \\
\text { claro }\end{array}$ & médio & marrom claro & branca/creme & amarela & sete & $\begin{array}{c}\text { marrom } \\
\text { claro }\end{array}$ \\
\hline 91 & $\begin{array}{c}\text { verde } \\
\text { arroxeado }\end{array}$ & presente & lanceolada & verde claro & $\begin{array}{c}\text { marrom } \\
\text { claro }\end{array}$ & médio & marrom claro & branca/creme & amarela & sete & $\begin{array}{c}\text { marrom } \\
\text { claro }\end{array}$ \\
\hline 94 & $\begin{array}{c}\text { verde } \\
\text { arroxeado }\end{array}$ & ausente & lanceolada & verde claro & prateado & médio & marrom claro & branca/creme & amarela & sete & $\begin{array}{c}\text { marrom } \\
\text { claro }\end{array}$ \\
\hline
\end{tabular}


Tabela 3. Caracterização morfológica dos clones de mandioca com base na coloração dos ramos terminais nas plantas adultas (CRT), comprimento das estípulas (CE), margem das estípulas (ME), hábito de ramificação (HR), sinuosidade do lóbulo foliar (SLF), forma da raiz (FR), tipo de planta (TP), comprimento médio da raiz (CMR), diâmetro médio da raiz (DMR), coloração das sépalas (CS) e coloração do disco da flor (CD). UnB/ Embrapa Cerrados, Brasília, DF, 2015.

\begin{tabular}{|c|c|c|c|c|c|c|c|c|c|c|c|}
\hline \multirow{2}{*}{ Clone } & \multicolumn{11}{|c|}{ Descritores morfológicos } \\
\hline & CRT & $\mathrm{CE}$ & $\mathrm{ME}$ & $\mathrm{HR}$ & SLF & FR & $\mathrm{TP}$ & CMR & DMR & $\mathrm{CS}$ & $\mathrm{CD}$ \\
\hline IAC 576-70 & verde & longas & laciniada & dicotômico & sinuoso & cilíndrica & compacta & intermediária & intermediária & verde & laranja \\
\hline 26 & $\begin{array}{l}\text { verde- } \\
\text { arroxeado }\end{array}$ & curtas & laciniada & tricotômico & sinuoso & $\begin{array}{l}\text { cônico- } \\
\text { cilíndrica }\end{array}$ & compacta & longa & finas & verde & laranja \\
\hline 215 & verde & longas & inteira & dicotômico & sinuoso & cônica & compacta & intermediária & intermediária & verde & laranja \\
\hline 246 & verde & longas & laciniada & tricotômico & sinuoso & $\begin{array}{l}\text { cônico- } \\
\text { cilíndrica }\end{array}$ & compacta & longa & intermediária & verde & laranja \\
\hline 259 & $\begin{array}{l}\text { verde- } \\
\text { arroxeado }\end{array}$ & curtas & laciniada & tricotômico & liso & $\begin{array}{l}\text { cônico- } \\
\text { cilíndrica }\end{array}$ & $\begin{array}{c}\text { guarda } \\
\text { sol }\end{array}$ & longa & intermediária & verde & roxo \\
\hline 272 & $\begin{array}{l}\text { verde- } \\
\text { arroxeado }\end{array}$ & longas & laciniada & dicotômico & sinuoso & $\begin{array}{l}\text { cônico- } \\
\text { cilíndrica }\end{array}$ & compacta & longa & intermediária & verde & laranja \\
\hline 273 & verde & longas & inteira & tricotômico & sinuoso & $\begin{array}{l}\text { cônico- } \\
\text { cilíndrica }\end{array}$ & compacta & longa & intermediária & verde & vermelha \\
\hline 446 & $\begin{array}{l}\text { verde- } \\
\text { arroxeado }\end{array}$ & longas & laciniada & dicotômico & sinuoso & cilíndrica & compacta & intermediária & finas & branca/creme & laranja \\
\hline 450 & $\begin{array}{l}\text { verde- } \\
\text { arroxeado }\end{array}$ & longas & laciniada & tricotômico & sinuoso & cilíndrica & compacta & intermediária & intermediária & verde & vermelha \\
\hline 497 & $\begin{array}{l}\text { verde- } \\
\text { arroxeado }\end{array}$ & curtas & laciniada & dicotômico & liso & $\begin{array}{l}\text { cônico- } \\
\text { cilíndrica }\end{array}$ & compacta & longa & intermediária & verde & laranja \\
\hline 83 & $\begin{array}{l}\text { verde- } \\
\text { arroxeado }\end{array}$ & curtas & laciniada & tricotômico & sinuoso & $\begin{array}{l}\text { cônico- } \\
\text { cilíndrica }\end{array}$ & compacta & intermediária & intermediária & verde & laranja \\
\hline 90 & $\begin{array}{l}\text { verde- } \\
\text { arroxeado }\end{array}$ & curtas & laciniada & dicotômico & sinuoso & $\begin{array}{l}\text { cônico- } \\
\text { cilíndrica }\end{array}$ & compacta & longa & finas & verde & laranja \\
\hline 91 & verde & curtas & laciniada & tricotômico & sinuoso & $\begin{array}{l}\text { cônico- } \\
\text { cilíndrica }\end{array}$ & compacta & longa & intermediária & verde & laranja \\
\hline 94 & verde & curtas & laciniada & dicotômico & sinuoso & $\begin{array}{l}\text { cônico- } \\
\text { cilíndrica }\end{array}$ & compacta & intermediária & finas & verde & laranja \\
\hline
\end{tabular}


Com base na análise visual da Figura 1 foi possível verificar a formação de três grupos de similaridade: i) IAC 576-70, Clone 446/08 e Clone 215/08; ii) Clone 26/08, Clone 90/08, Clone 246/08, Clone 91/08, Clone 83/08, Clone 272/08, Clone 94/08, Clone 273/08, Clone 450/08; e iii) Clone 259/08 e Clone 497/08. Com base no coeficiente de correlação cofenética do dendrograma $(r=0,80)$ verificou-se elevado ajuste entre a representação gráfica e a matriz de dissimilaridade, o que permite a realização das inferências por meio da avaliação visual da Figura 1. Esta clara subdivisão dos genótipos em diferentes grupos de similaridade não foi verificada nos trabalhos realizados por DUPUTIÉ et al. (2009) e VIEIRA et al. (2011). Estes autores não encontraram uma clara estruturação da diversidade genética, o que pode ser explicado pelo fato de haver uma constante troca de genótipos entre os produtores de diferentes regiões, gerando fluxo gênico e dificuldades na identificação da origem exata dos acessos.

Foi evidenciado por meio da matriz de dissimilaridade genética entre os acessos evidenciou que os clones geneticamente mais próximos foram o 246/08 e o 91/08 com uma dissimilaridade de 0,09 (Figura 1), os quais têm a mesma genealogia. A maior distância genética foi observada entre os clones 259/08 com polpa amarelada e IAC 576-70 variedade padrão recomendada para o plantio na região do Cerrado brasileiro, com uma dissimilaridade de 0,68. 


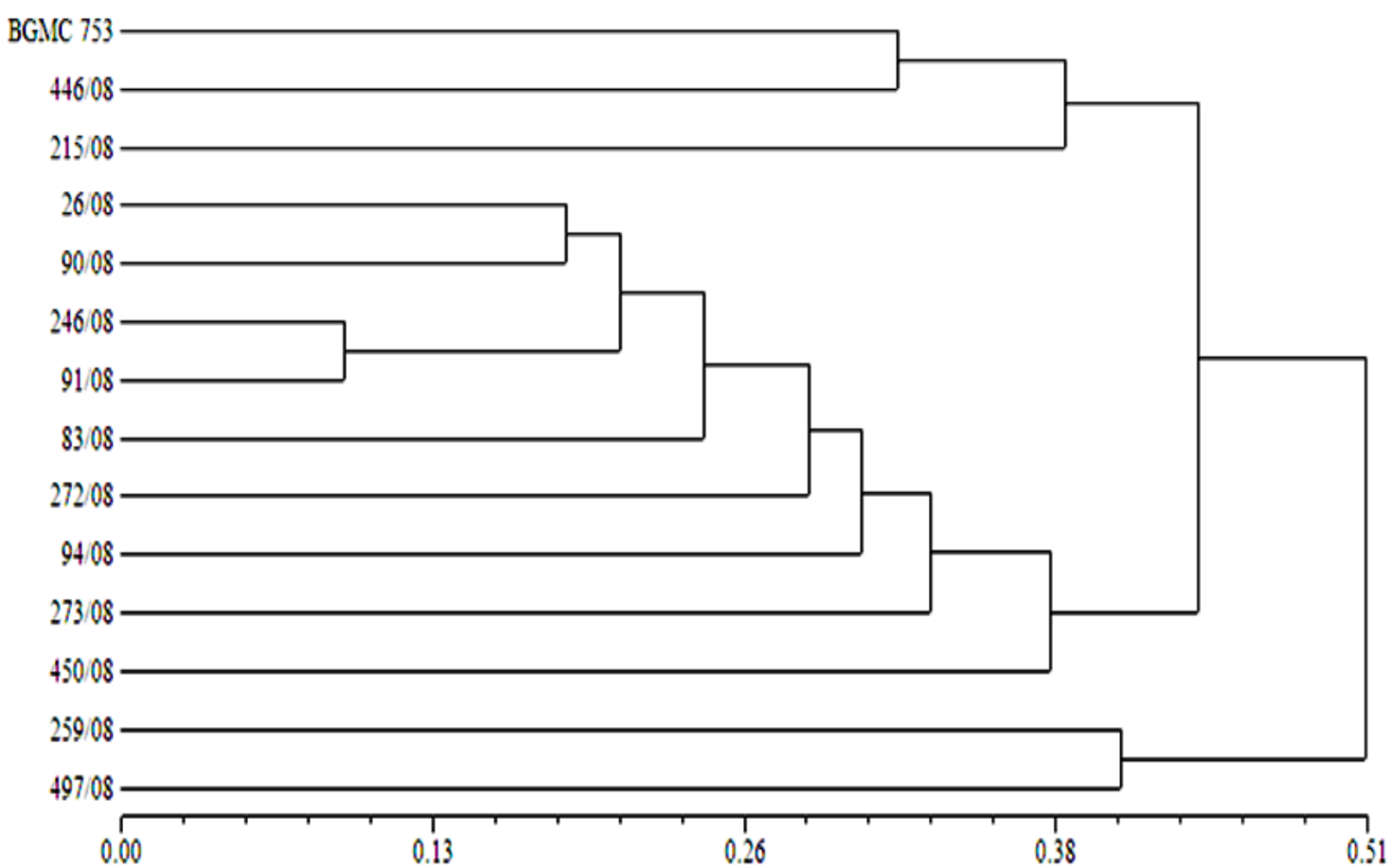

Figura 1. Análise de agrupamento de 14 clones de mandioca, obtido pelo método de agrupamento UPGMA, com base na matriz de dissimilaridade genética obtida por meio do complemento do índice de similaridade de coincidência simples, utilizando 22 descritores morfológicos qualitativos. $\mathrm{O}$ valor do coeficiente de correlação cofenética (r) é de 0,80 .

A maior dissimilaridade genética entre os clones 259/08 e o IAC 576-70 é corroborada pelas diferenças desses dois genótipos em vários descritores: coloração da folha apical, forma do lóbulo central da folha, coloração do córtex do caule, coloração da epiderme externa do caule, coloração da película da raiz, coloração do córtex da raiz, coloração da epiderme interna do caule, coloração dos ramos terminais nas plantas adultas, comprimento das estípulas, hábito de ramificação, sinuosidade do lóbulo foliar, forma da raiz, tipo de planta, comprimento médio da raiz, e coloração do disco da flor. Na Figura 2, destacam-se alguns desses caracteres que diferenciam os clones 259/08 e IAC 576-70. No trabalho de MKUMBIRA et al. (2003), relatam-se que os agricultores tradicionais apresentam elevada acurácia na diferenciação das cultivares de mandiocabrava e mansa que mantêm sob cultivo, utilizando caracteres morfológicos mais detalhados intuitivamente para diferenciar as plantas. 
1
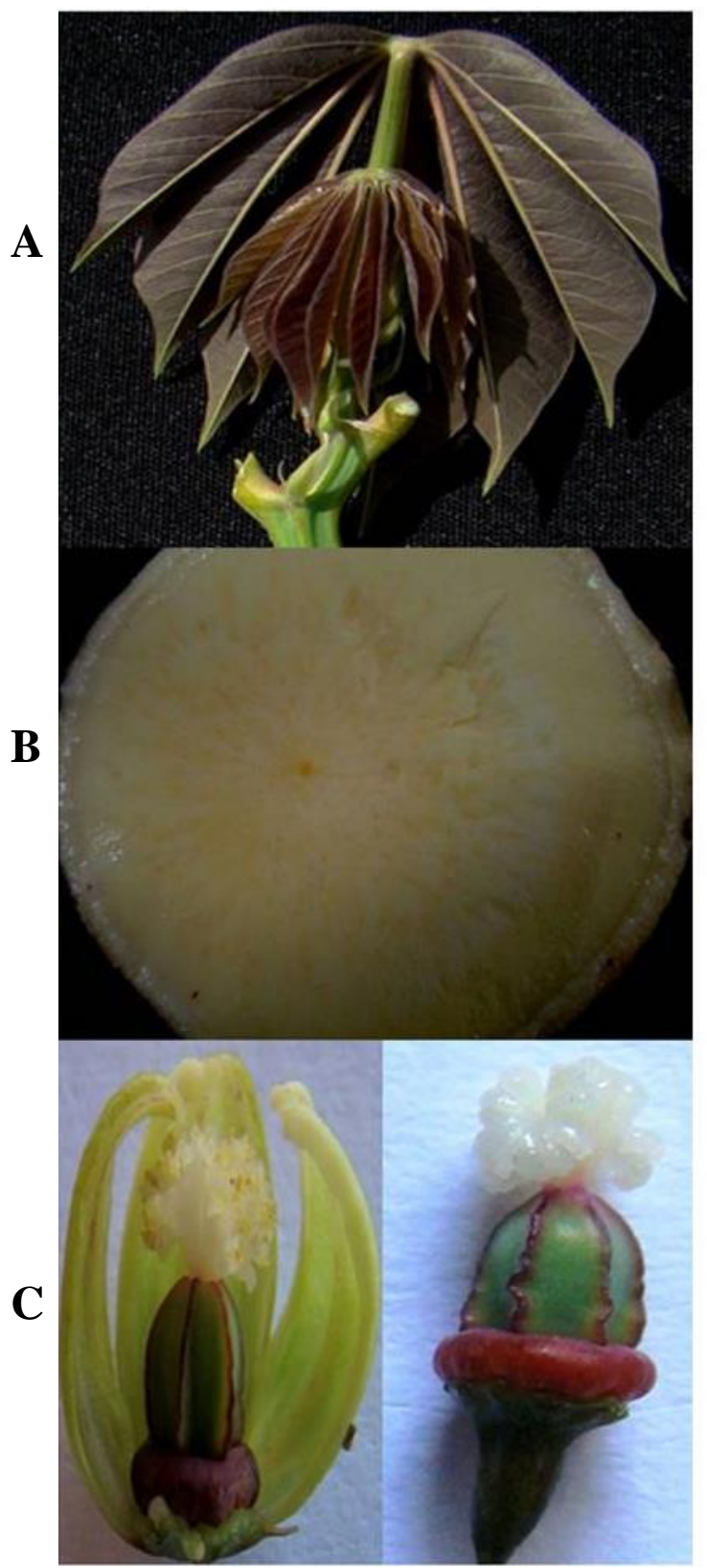

2

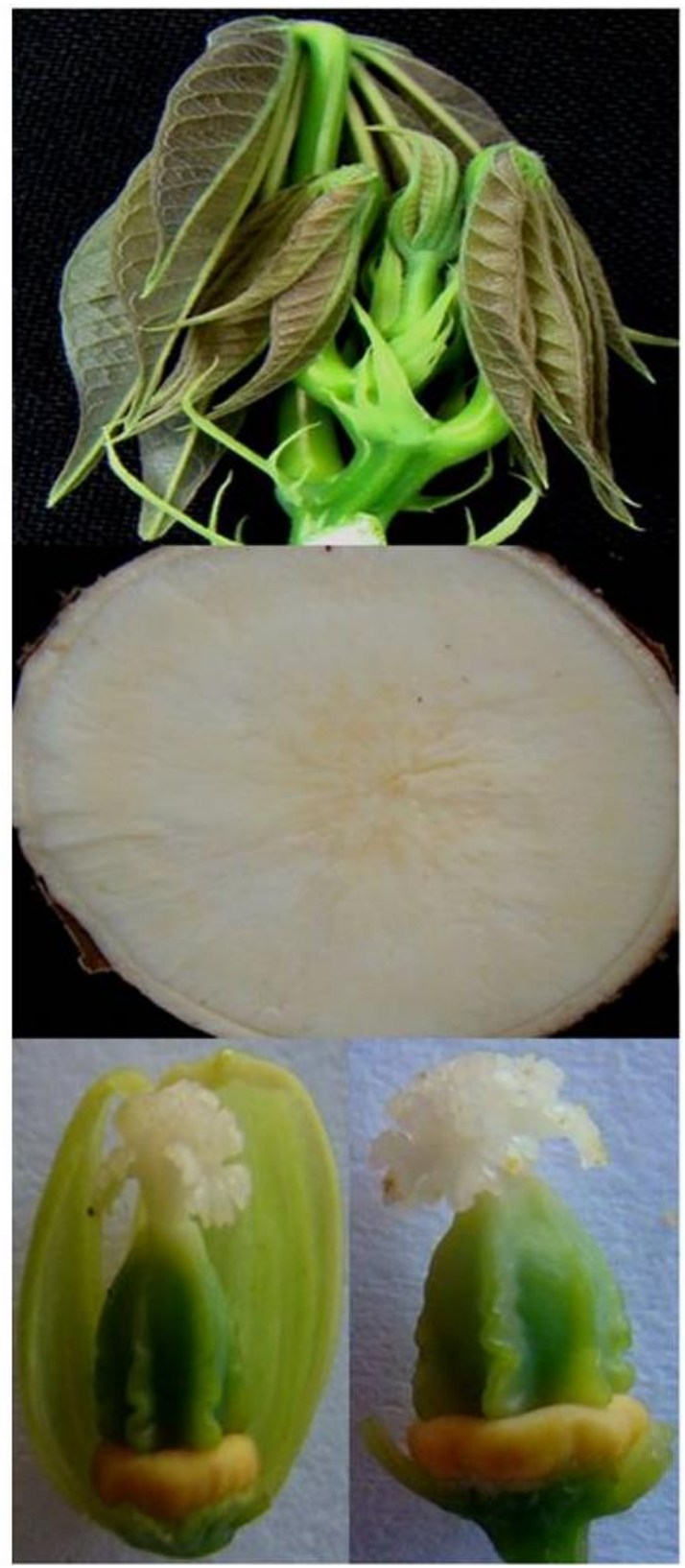

Figura 2. Comparação de dissimilaridade entre o clone 259 (1) e a testemunha IAC 576-70 (2) com relação à coloração das folhas apicais (A), coloração da polpa da raiz (B) e coloração do disco da flor (C).

Dentre os caracteres aferidos, alguns se destacaram em função de expressarem elevada entropia: coloração da epiderme externa $(1,47)$; forma do lóbulo central da folha $(1,34)$ e cor do córtex da raiz $(0,90)$ (Tabela 4). Estes caracteres apresentam em comum o fato de serem pouco relacionados com caracteres agronômicos de interesse o que provavelmente fez com que estes fossem pouco visados durante o processo de seleção realizado tanto pelos melhoristas como pelos produtores no início da domesticação da espécie (VIEIRA et al., 2008).

Dentre os caracteres avaliados, alguns são de grande importância para o 
melhoramento, como a coloração da polpa da raiz que é de grande importância comercial para a mandioca de mesa, uma vez que os agricultores e consumidores têm preferência por cultivares com polpa amarelada. A coloração amarela da polpa está diretamente relacionada com a presença de compostos com atividade de pró-vitamina A, destacando-se os genótipos com coloração da polpa amarela com maior concentração de $\beta$-caroteno (MEZETTE et al, 2009; CARVALHO et al., 2012 ). Dentre os genótipos avaliados, $79 \%$ dos clones apresentaram cor da polpa das raízes amarela e $21 \%$ apresentaram cor creme.

Quanto às constrições nas raízes, os programas de melhoramento genético objetivam cultivares com poucas constrições e, em geral, 93\% dos genótipos expressaram esse fenótipo desejável. Outro caractere de importância é o comprimento médio das raízes, uma vez que os consumidores de mandioca têm preferência por cultivares com raízes de tamanho médio. Entre os genótipos avaliados, $43 \%$ expressaram esse fenótipo desejável. Outros caracteres também apresentam fenótipos desejáveis como: i) tipo de planta, o ideal é o fenótipo com forma da planta compacta, o qual está intimamente relacionado à facilidade de práticas culturais, sendo observado em 93\% dos genótipos avaliados, ii) coloração da película da raiz, sendo que o ideal para a produção de mandioca de mesa são as mandiocas com coloração externa da raiz marrom, o que foi observado em $71 \%$ dos genótipos.

Com base nos resultados obtidos neste trabalho, sugere-se que no grupo de clones avaliados há alguns com potencial para recomendação para cultivo comercial, uma vez que vários deles têm caracteres desejáveis sob o ponto de vista agronômico. Trabalhos complementares de desempenho agronômico e também de análise das qualidades nutricionais estão sendo realizados em várias regiões do Cerrado, tendo como objetivo finalístico, o desenvolvimento e disponibilização de cultivares melhorada para a região.

Tabela 4. Caracteres avaliados, classes fenotípicas, frequência de clones e estimativa do coeficiente de entropia em cada uma das classes. UnB/ Embrapa Cerrados, Brasília, DF, 2015.

\begin{tabular}{cccc}
\hline Caracteres & Classes fenotípicas & $\begin{array}{c}\text { Frequência dos } \\
\text { genótipos }(\%)\end{array}$ & $\begin{array}{c}\text { Entropia } \\
(\mathbf{H})\end{array}$ \\
\hline Coloração da folha apical & $\begin{array}{c}\text { verde arroxeado } \\
\text { roxo }\end{array}$ & 86 & 0,41 \\
Pubescência do broto apical & ausente & 43 & 0,68 \\
Forma do lóbulo central da folha & presente & 57 & 1,34
\end{tabular}




\begin{tabular}{|c|c|c|c|}
\hline & $\begin{array}{c}\text { Lanceolada } \\
\text { linear } \\
\text { linear-pandurada } \\
\text { obovada-lanceolada }\end{array}$ & $\begin{array}{c}43 \\
7 \\
7 \\
14\end{array}$ & \\
\hline Coloração do córtex do caule & $\begin{array}{l}\text { verde claro } \\
\text { verde escuro }\end{array}$ & $\begin{array}{l}86 \\
14\end{array}$ & 0,41 \\
\hline $\begin{array}{c}\text { Coloração da epiderme externa do } \\
\text { caule }\end{array}$ & $\begin{array}{c}\text { laranja } \\
\text { verde amarelado } \\
\text { marrom claro } \\
\text { prateado } \\
\text { marrom escuro }\end{array}$ & $\begin{array}{c}7 \\
7 \\
43 \\
29 \\
14\end{array}$ & 1,47 \\
\hline Comprimento da filotaxia & $\begin{array}{l}\text { curto }(<8 \mathrm{~cm}) \\
\text { médio }(8-15 \mathrm{~cm})\end{array}$ & $\begin{array}{l}14 \\
86\end{array}$ & 0,41 \\
\hline Coloração da película da raiz & $\begin{array}{c}\text { amarelo } \\
\text { marrom claro } \\
\text { marrom escuro }\end{array}$ & $\begin{array}{c}7 \\
86 \\
7\end{array}$ & 0,51 \\
\hline Coloração do córtex da raiz & $\begin{array}{c}\text { branco ou creme } \\
\text { amarelo } \\
\text { rosado }\end{array}$ & $\begin{array}{c}43 \\
50 \\
7\end{array}$ & 0,90 \\
\hline Coloração da polpa da raiz & $\begin{array}{l}\text { creme } \\
\text { amarela }\end{array}$ & $\begin{array}{l}21 \\
79\end{array}$ & 0,52 \\
\hline $\begin{array}{l}\text { Número predominante de lóbulos } \\
\text { nas folhas }\end{array}$ & $\begin{array}{l}\text { cinco } \\
\text { sete }\end{array}$ & $\begin{array}{l}14 \\
86\end{array}$ & 0,41 \\
\hline $\begin{array}{l}\text { Coloração da epiderme interna do } \\
\text { caule }\end{array}$ & $\begin{array}{c}\text { creme } \\
\text { marrom claro }\end{array}$ & $\begin{array}{c}7 \\
93\end{array}$ & 0,26 \\
\hline $\begin{array}{c}\text { Coloração dos ramos terminais nas } \\
\text { plantas adultas }\end{array}$ & $\begin{array}{c}\text { verde } \\
\text { verde-arroxeado }\end{array}$ & $\begin{array}{l}43 \\
57\end{array}$ & 0,68 \\
\hline Comprimento das estípulas & $\begin{array}{l}\text { curtas } \\
\text { longas }\end{array}$ & $\begin{array}{l}50 \\
50\end{array}$ & 0,69 \\
\hline Margem das estípulas & $\begin{array}{l}\text { laciniada } \\
\text { inteira }\end{array}$ & $\begin{array}{l}86 \\
14\end{array}$ & 0,41 \\
\hline Hábito de ramificação & $\begin{array}{l}\text { dicotômica } \\
\text { tricotômica }\end{array}$ & $\begin{array}{l}50 \\
50\end{array}$ & 0,69 \\
\hline Sinuosidade do lóbulo foliar & $\begin{array}{l}\text { liso } \\
\text { sinuoso }\end{array}$ & $\begin{array}{l}14 \\
86\end{array}$ & 0,41 \\
\hline Forma da raiz & $\begin{array}{c}\text { cônica } \\
\text { cônica-cilíndrica } \\
\text { cilíndrica }\end{array}$ & $\begin{array}{c}7 \\
72 \\
21\end{array}$ & 0,76 \\
\hline Tipo de planta & $\begin{array}{l}\text { compacta } \\
\text { guarda sol }\end{array}$ & $\begin{array}{c}93 \\
7\end{array}$ & 0,26 \\
\hline Comprimento médio da raiz & $\begin{array}{l}\text { intermediária }(20-30 \mathrm{~cm}) \\
\text { longa }(>30 \mathrm{~cm})\end{array}$ & $\begin{array}{l}43 \\
57\end{array}$ & 0,68 \\
\hline Diâmetro médio da raiz & $\begin{array}{c}\text { finas }(<5 \mathrm{~cm}) \\
\text { intermediária }(5-8 \mathrm{~cm})\end{array}$ & $\begin{array}{l}29 \\
71\end{array}$ & 0,60 \\
\hline Coloração das sépalas & $\begin{array}{l}\text { branca/creme } \\
\text { verde }\end{array}$ & $\begin{array}{c}7 \\
93\end{array}$ & 0,26 \\
\hline Coloração do disco da flor & $\begin{array}{c}\text { roxo } \\
\text { laranja } \\
\text { vermelha }\end{array}$ & $\begin{array}{c}7 \\
79 \\
14\end{array}$ & 0,66 \\
\hline
\end{tabular}




\subsection{CONCLUSÕES}

O uso de descritores morfológicos utilizados no trabalho foi eficaz na diferenciação dos genótipos de mandioca, indicando a utilidades desses descritores para fins de ensaios de caracterização de genótipos visando à proteção de cultivares de mandioca.

No grupo de clones avaliados, há genótipos com potencial para recomendação para cultivo comercial, uma vez que vários deles têm caracteres morfológicos desejáveis do ponto de vista agronômico e comercial. 


\subsection{REFERÊNCIAS BIBLIOGRÁFICAS}

ALBUQUERQUE, J. A. A. SEDIYAMA, T.; SILVA, A. A. da; SEDIYAMA, C. S.; ALVES, J. M. A.; NETO, F. de A. Caracterização morfológica e agronômica de clones de mandioca cultivados no Estado de Roraima. Revista Brasileira de Ciências Agrárias, v. 04, n. 04, p. 388-394, 2009.

BRASIL. Ministério da Agricultura, Pecuária e Abastecimento. Proteção de cultivares. Brasília, DF, 2010. Disponível em: <http://www.agricultura.gov.br/vegetal/registrosautorizacoes/protecao-cultivares/formularios-protecao-cultivares>. Acesso em: 16 fev. de 2010.

CARVALHO, L. J. C. B.; LIPOLIS, J. ; CHEN, S.; SOUZA, C. R. B.; VIEIRA, E.A.; JAMES, V. A. Characterization of carotenoid-protein complexes and gene expression analysis associated with carotenoid sequestration in pigmented cassava (Manihot Esculenta Crantz) storage root. The Open Biochemistry Journal, v. 6, p. 116-130, 2012. doi: 10.2174/1874091X01206010116.

CEBAllos, H.; IGLESIAS, C. A.; PÉREZ, J. C.; DIXON, A. G. O. Cassava breeding: opportunities and challenges. Plant Molecular Biology, v.56, Dordrecht, n.4, p.503$516,2004$.

CRUZ, C.D. Programa genes: aplicativo computacional em genética e estatística. Viçosa: UFV, 2001. 648p.

DUPUTIÉ, A. et al. Traditional Ameridian cultivators combine directional and ideotypic selection for sustainable management of cassava genetic diversity. Journal of Evolutionary Biology, v. 22, n.06, p. 1317-1325, 2009.

FAO. Maiores produtores mundiais de mandioca.<http:// apps.fao.org/egibin/nphdb.pl2005.> Acesso em 15 jan. 2013.

FIALHO, J. F.; VIEIRA, E. A.; SILVA, M. S.; PAULA-MORAES, S. V.; FUKUDA, W. M. G.; SANTOS FILHO, M. O. S; SILVA, K. N. Desempenho de variedades de mandioca de mesa no Distrito Federal. Revista Brasileira de Agrociência, v.15, n. 1-4, p. 31-35, 2009.

FIALHO, J.F.; VIEIRA, E.A. Manejo e tratos culturais da mandioca. In: FIALHO, J.F.; VIEIRA, E.A. (Eds.). Mandioca no Cerrado: orientações técnicas. 2. ed. Planaltina: Embrapa Cerrados, 2013. p. 61-88.

FUKUDA, W. M. G.; GUEVARA, C. L. Descritores morfológicos e agronômicos para a caracterização de mandioca (Manihot esculenta Crantz). Cruz das Almas: CNPMF, 1998, 38p. 
IBGE. Disponível <http://www.ibge.gov.br>. Acesso em 15 jan. 2013.

IGLESIAS, C.; MAYER, J. CHAVÉZ, L. CALLE, F. Genetic potential and stability of carotene contend in cassava roots. Euphytica. 94: 363-373,.1997.

INSTITUDO BRASILEIRO DE GEOGRAFIA E ESTATÍSTICA (IBGE). Sistema IBGE de recuperação automática - SIDRA. 2011. Disponível em: <http://www.sidra.ibge.gov.br/>. Acesso em: 15 out. 2013.

KLINK, C.A.; MACHADO, R.B. Conservation of the Brazilian Cerrado. Conservation Biology, v.19, p.707-713, 2005.

MEZETTE, T. F. et al. Seleção de clones-elite de mandioca de mesa visando a características agronômicas, tecnológicas e químicas. Bragantia, v. 68, n. 03, p. 601609, 2009.

MKUMBIRA, J.; CHIWONA-KARLTUN, L.; LANGERCRANTZ, U.; MAHUNGU, N. M.; SAKA, J. MHONE, A.; BOKANGA, M.; BRIMER, L.; GULLBERG, U.; ROSLING, H. Classification of cassava into 'bitter' and 'cool' in Malawi: From farmers perception characterisation by molecular markers. Euphytica, v. 132, p.7-22, 2003.

NICK, C.; CARVAlHO, M.; ASSIS, L. H. B. de; CARVAlHO, S. P. de. Genetic dissimilarity in cassava clones determined by multivariate techniques. Crop Breeding and Applied Genetics, v. 08, n. 02, p. 104-110, 2008.

PILLAR, V.P. Multivariate exploratory analysis and randomization testing using Multiv. Coenoses, v.12, n.1, p.145-148, 1997.

RATTER, J.J.; RIBEIRO, J.F.; BRIDGEWATER, S. The Brazilian Cerrado vegetation and threats to its biodiversity. Annals of Botany, v.80, p.223-230, 1997.

ROHLF, F. J. NTSYS-pc: numerical taxonomy and multivariate analysis system, version 2.1. New York: Exeter Software, 2000. 98p.

SOKAL, R.R.; ROHLF, F.J. The comparison of dendrograms by objective methods. Taxon, v.11, p.30-40, 1962.

VIEIRA, E. A.; FIALHO, J. F.; FALEIRO, F. G.; BELLON, G.; FONSECA, K. G.; CARVAlHO. L. J. C. B.; SILVA, M. S.; PAUlA-MORAES, S. V.; OlIVEIRA, C. M.; DENKE, M. L. Characterization of sweet cassava acessions based on molecular, quantitative and qualitative data. Crop Breeding and Applied Biotechnology, v.11, n.3, p.232-240, 2011.

VIEIRA, E.A. ; FIALHO, J. de F.; SILVA, M. S. ; FUKUDA, W. M. G.; FALEIRO, F. G. Variabilidade genética do banco de germoplasma de mandioca da Embrapa Cerrados acessada por meio de descritores morfológicos. Científica, v. 36, p. 56-67, 2008. 
VIEIRA, E.A.; FIALHO, J.F.; FALEIRO, F.G.; BELLON, G.; FONSECA, K.G.; SILVA, M.S.; PAULA-MORAES, S.V.; CARVALHO. L.J.C.B. Caracterização fenotípica e molecular de acessos de mandioca de indústria com potencial de adaptação às condições do cerrado do Brasil Central. Semina: Ciências Agrárias, v.34, p.567$582,2013$.

VIEIRA, E.A.; FIALHO, J.F.; SILVA, M.S. Recursos genéticos e melhoramento da mandioca In: FIALHO, J.F.; VIEIRA, E.A. (Eds). Mandioca no Cerrado: orientações técnicas. Brasília-DF: Embrapa Cerrados, v.1, p. 25-35, 2011.

WELCH, R. M.; GRAHAN, R. D. Breeding crops for enhanced micronutrient content. Plant and Soil, v. 245, n. 01, p. 205-214, 2002. 
CAPÍTULO 2. CARACTERES AGRONÔMICOS E BIOQUÍMICOS DE CLONES ELITE DE MANDIOCA DE MESA DE POLPA AMARELADA BIOFORTIFICADA

CHAPTER 2. AGRONOMIC AND BIOCHEMICAL CHARACTERS IN SWEET CASSAVA ELITE CLONES WITH BIOFORTIFIED YELLOWISH PULP 


\section{RESUMO}

A raiz de reserva de mandioca (Manihot esculenta Crantz ) é o alimento básico de grande parte da população de baixa renda de algumas regiões do Brasil, sendo consumida principalmente na forma de farinha. Este trabalho teve como objetivo, avaliar por meio de caracteres agronômicos e bioquímicos 13 clones de mandioca, em comparação com a variedade testemunha IAC 576-70. Os experimentos conduzidos na Embrapa Cerrados por duas safras. Foi utilizado o delineamento experimental de blocos casualizados com três repetições. As médias dos caracteres foram agrupadas por meio do teste aglomerativo de SCOTT \& KNOTT a 5\% de probabilidade de erro. Os resultados destacaram com base nos caracteres altura da primeira ramificação, os clones (273/08 e 259/08), altura da planta (90/08, 272/08, 273/08, 497/08, 259/08 e 450/08), peso da parte aérea sem a cepa (94/08 e 272/08), porcentagem de amido nas raízes (26/08, 272/08, 259/08 e 450/08) e produtividade de raízes (215/08). Com relação ao tempo de cocção na safra 2011/2012, todos os clones apresentaram tempo inferior a 30 minutos. Com relação ao teor de carotenóides totais nas raízes os clones que se destacaram foram 91/08, 94/08, 215/08, 246/08, 272/08 e 497/08. Em relação ao teor de proteínas nas raízes, se destacaram os clones 26/08, 90/08 e 91/08. Os teores de HCN nas raízes de reserva de mandioca foram inferiores a $100 \mathrm{mg} \mathrm{Kg}^{-1} \mathrm{em}$ todos os clones avaliados. Com base nos caracteres agronômicos e bioquímicos verifica-se a existência de clones com potencial para recomendação para cultivo comercial na região.

Palavras-chaves: Manihot esculenta Crantz, melhorameto genético, caracteres agronômico, caracteres bioquímico, clone, biofortificação, recursos genéticos 


\begin{abstract}
The reserve root of cassava (Manihot esculenta Crantz) is the staple food for great part of the low-income population in some regions of Brazil, being consumed mainly in the form of flour. The objective of this work was to evaluate by means of characterize agronomic and biochemical, 13 cassava clones, compared with the control variety IAC 576-70, evaluated in experiments conducted at Embrapa Cerrado for two crop seasons. An experimental randomized block design with three replications was used. The mean characters were grouped by the agglomerative SCOTT \& Knott test at 5\% probability of error.The results showed based on the characters height of the first branch, the clones (273/08 and 259/08), plant height (90/08, 272/08, 273/08, 497/08, 259/08 and 450/08), shoot weight without strain (94/08 and 272/08), percentage of starch in the roots $(26 / 08$, 272/08, 259/08 and 450/08) and productivity roots (215/08). Regarding the cooking time in the 2011/2012 harvest, all clones showed time less than 30 minutes. Regarding the total carotenoid content in the roots clones that stood out were 91/08, 94/08, 215/08, 246/08, 272/08 and 497/08, in relation to the protein highlighted in the clones roots 26 / 08, 90/08 and 91/08. The levels of HCN in reserve roots of cassava were less than 100 $\mathrm{mg} \mathrm{Kg}{ }^{-1} \mathrm{em}$ all evaluated clones. Based on agronomic and biochemical characters there were clones with potential for recommendation for commercial cultivation in the region.
\end{abstract}

Key words: Manihot esculenta Crantz, genetic breeding, characterize agronomic, characterize biochemical, clone, biofortified, genetic resources 


\subsection{INTRODUÇÃO}

A mandioca (Manihot esculenta Crantz ) é uma planta da família Euforbiaceae cultivada, principalmente, em função de suas raízes tuberosas ricas em amido. A espécie apresenta considerável tolerância à seca e se adapta as mais variadas condições de clima e solo. A parte mais utilizada da planta são as raízes tuberosas, ricas em amido, e constitui-se numa das mais importantes fontes de calorias na dieta de vários países tropicais (COCK, 1985).

O melhoramento genético de mandioca de mesa tem focado no desenvolvimento de variedades com teores de ácido cianídrico $(\mathrm{HCN})$ nas raízes de reserva inferiores a $100 \mathrm{mg} \mathrm{Kg}{ }^{-1}$ de raízes frescas, elevada produtividade de raízes de reserva, raízes de reserva com boas qualidades culinárias, como baixo tempo para o cozimento, poucas fibras, massa pegajosa, sabor e aroma agradavél, plantas com arquitetura favorável a práticas culturais e ao plantio mecanizado, com elevada altura da primeira ramificação, elevada resistência a pragas e doenças, raízes lisas ou com poucas cintas, dentre outros caracteres de importância (FUKUDA et al., 2002).

A mandioca apresenta potencial genético para ser fonte de carotenóides e licopeno para a alimentação humana. No caso dos carotenóides, destaque especial para o $\beta$-caroteno, precursor da vitamina $A$, presente em genótipos com raízes de coloração amarela (MEZZETE et al., 2009; CHÁVEZ et al., 2005). O licopeno, presente em raízes de coloração rosada, exibe propriedades antioxidantes que protegem o corpo contra radicais livres (SHAMI \& MOREIRA, 2004). A possibilidade da mandioca ser além de fonte de calorias para as populações mais carentes do mundo, também ser fonte de vitamina A e licopeno permitiria melhorar a nutrição dos habitantes de países em desenvolvimento e agregar valor às variedades destinadas ao consumo humano (WELSH \& GRAHAM, 2002).

Os carotenóides são pigmentos presentes em plantas e alimentos que têm sido alvo de vários estudos em nutrição humana na prevenção de doenças, atribuindo sua ação às suas propriedades antioxidantes. Um dos mais conhecidos carotenóides é o $\beta$ caroteno, molécula precursora da vitamina A cuja composição é exatamente a metade deste carotenóide (RODRIGUEZ-AMAYA \& KIMURA, 2004). A carência desta vitamina é uma das maiores deficiências nutricionais da população mundial, gerando sérios problemas de saúde, sendo o principal a cegueira noturna em crianças. Esta situação é um problema que afeta também os brasileiros, principalmente aqueles de 
baixa renda que vivem em zonas rurais e especialmente em regiões semi-áridas (SOUZA \& VILLAS BOAS, 2002).

Os programas de melhoramento genético de mandioca de mesa estão atualmente direcionados no desenvolvimento de variedades biofortificadas que unem aos caracteres agronômicos a presença de carotenóides como $\beta$-caroteno e licopeno nas raízes tuberosas de coloração amarelada e rosada, respectivamente (NASSAR, 2007; MEZZETE et al., 2009). Tais variedades podem ser utilizadas de forma direta pelos produtores ou indireta no desenvolvimento de variedades adaptadas a diferentes agroecossistemas e regiões do Brasil. Estudos realizados com os recursos genéticos disponíveis no Brasil vêm demostrando que no germoplasma de mandioca existe variabilidade disponível para esse fim em acessos de mandioca com coloração das raízes amarelas e rosadas (VIEIRA et al., 2011a; CARVALHO et al., 2012). Por meio de trabalhos de melhoramento genético, clones muito promissores têm sido obtidos, os quais estão sendo avaliados em condições comerciais com o uso da metodologia de melhoramento participativo (VIEIRA et al., 2008)

Neste trabalho, objetivou-se avaliar as características agronômicas e bioquímicas em raízes de reserva de clones elite de mandioca amarela de mesa, tendo em vista que tais características refletem o real potencial produtivo e qualitativo dos clones visando à utilização direta pelos produtores e/ou a utilização como genitores em programas de melhoramento genético de mandioca de mesa.

\subsection{MATERIAL E MÉTODOS}

O trabalho foi conduzido no campo experimental e no Laboratório de Raízes e Tubérculos da Embrapa Cerrados (CPAC), em Planaltina-DF, entre outubro de 2010 e outubro de 2011 e entre novembro de 2011 e novembro de 2012. A Embrapa Cerrados está situada à $15^{\circ} 39^{\prime} 84^{\prime \prime}$ de latitude $\mathrm{S}$ e $47^{\circ} 44^{\prime} 41^{\prime}$ " de longitude $\mathrm{W}$, latitude de 1.000 metros, em Latossolo Vermelho Escuro, textura argilosa, No período de condução dos experimentos (safras 2010/2011 e 2011/2012), respectivamente, as médias das temperaturas máximas diárias foram de $27,88^{\circ} \mathrm{C}$ e $28,27^{\circ} \mathrm{C}$, as médias das temperaturas mínimas diárias foram de $16,05^{\circ} \mathrm{C}$ e $16,77^{\circ} \mathrm{C}$, as médias das temperaturas médias diárias foram de $21,28^{\circ} \mathrm{C}$ e $21,77^{\circ} \mathrm{C}$, as médias de umidade relativa do ar foram de $68,96 \%$ e $66,79 \%$, as velocidades médias dos ventos foram de $2,03 \mathrm{~m} \mathrm{seg}^{-1}$ e $2,08 \mathrm{~m} \mathrm{seg}^{-1}$, as médias de horas de insolação diária foram de 7,03 h e 6,88 h, as médias de radiação 
diárias foram de 18,98 $\mathrm{MJ} \mathrm{m}^{-2}$ e 19,14 $\mathrm{MJ} \mathrm{m}^{-2}$, as precipitações acumuladas foram de $1367 \mathrm{~mm}$ e $1402 \mathrm{~mm}$ e as médias de evapotranspiração potencial foram de 4,23 mm e $4,31 \mathrm{~mm}$.

Para a realização do estudo foram caracterizados treze clones elite de mandioca amarela de mesa (clone 26/08, clone 83/08, clone 90/08, clone 91/08, clone 94/08, clone 215/08, clone 246/08, clone 259/08, clone 272/08, clone 273/08, clone 446/08, clone 450/08 e clone 497/08) selecionados para as condições do Cerrado, sendo utilizada como testemunha a variedade de mandioca de mesa IAC 576-70, que no Banco de Germoplasma de Mandioca do Cerrado (BGMC) está identificada como BGMC 753 e que é indicada para o cultivo na região (FIALHO et al., 2009).

O delineamento experimental utilizado foi de blocos casualizados com três repetições, sendo que cada parcela foi composta por 4 linhas de 10 plantas, com espaçamento de 0,80 m entre plantas e 1,20 m entre linhas. No processo de caracterização foram utilizadas as 16 plantas centrais de cada parcela, sendo que as avaliações foram feitas em 2010/2011 e repetidas em 2011/2012. A seleção do material de propagação e as práticas culturais seguiram as recomendações do sistema de produção de mandioca para a região do Cerrado (FIALHO et al., 2013, FIALHO \& VIEIRA, 2013).

Os descritores agronômicos foram avaliados no local dos experimentos e no Laboratório de Raízes e Tubérculos nos dois anos. Foram avaliados seis descritores quantitativos: 1) altura da planta em metro (AP); 2) altura da primeira ramificação em metro (APR); 3) peso da parte aérea sem a cepa em $\mathrm{Kg} \mathrm{ha}^{-1}$ (PPA); 4) produtividade de raízes em $\mathrm{Kg} \mathrm{ha}^{-1}(\mathrm{PR})$; 5) porcentagem de amido nas raízes por meio do método da balança hidrostática (AM), descrito por GROSMANN \& FREITAS (1950); 6) tempo para a cocção em minutos (TC) de acordo com o método descrito por BORGES et al. (2002).

Caracteres bioquímicos foram avaliados três no Laboratório de Raízes e Tubérculos e no Laboratório de bioquímica nos dois anos. Como teor de ácido cianídrico nas raízes $\left(\mathrm{mg} \mathrm{Kg}^{-1}\right)$ por meio do método qualitativo, descrito por WILLAMS \& EDWARDS (1980), a partir de cinco raízes de reserva tomadas ao acaso por parcela.

Para a determinação do teor de carotenóides nas raízes de reserva, no momento da colheita em campo, três raízes de reserva (RR) uniformes de mandioca padrão comercial de cada parcela experimental foram selecionadas, identificadas e imediatamente colocadas em caixas de isopor com gelo, as quais foram levadas ao 
Laboratório. Sob baixa iluminação, as amostras foram lavadas, descartando-se os tecidos mais externos (periderme, cambio e floema), amostrando-se pedaços de $1 \mathrm{~cm}$ de espessura para compor a amostra de análise. As amostras foram lavadas em água deionizada e purificada em sistema Milli-q, secadas em papel toalha, identificadas, embaladas em papel alumínio e imediatamente congeladas em nitrogênio líquido. Após esse congelamento, as amostras foram armazenadas à $-80^{\circ} \mathrm{C}$. As amostras foram liofilizadas até a desidratação completa, maceradas com o uso de gral e pistilo de porcelana, mantendo-se o resfriamento com nitrogênio líquido, até a obtenção de pó uniforme, o qual foi armazenado à $-80^{\circ} \mathrm{C}$ até sua utilização.

Para a extração e a quantificação de carotenóides totais foi utilizado cerca de 100 mg de pó da raiz de reserva, o qual foi hidratado com $3 \mathrm{~mL}$ de tampão de extração (TEx) composto com Tris $50 \mathrm{mM}$ pH 7,6, NaCl $100 \mathrm{mM}$, EDTA $5 \mathrm{mM}$. As etapas para a extração de carotenóides utilizadas neste trabalho foram as mesmas descritas por CARVALHO et al. (2013).

Após a extração, os carotenóides totais foram quantificados por meio da leitura da densidade ótica do extrato no comprimento de onda variando de 300 a 550ฤm, com leitura em 450 ๆm, a partir dos dados das avaliações calculou-se o teor de carotenóides totais em $\mu \mathrm{g} \mathrm{g}^{-1}(\mathrm{CT})$, conforme modelo matemático proposto por RODRIGUEZAMAYA \& KIMURA (2004):

$$
\mathrm{CT}=\frac{\mathrm{OD} \times 10^{4} \times \mathrm{V}}{A \%^{1}{ }_{1 \mathrm{~cm}} \times \mathrm{DWt}}
$$

Em que:

CT: teor de carotenóides totais;

$\mathrm{OD}=$ densidade ótica da amostra no $\lambda \max$,

$A^{1}{ }_{1 \mathrm{~cm}}=2592$ - coeficiente de extinção do $\beta$-caroteno em éter de petróleo;

$\mathrm{V}=$ volume da extração $(\mathrm{mL})$;

DWt $=$ peso do pó desidratado de raiz de reserva.

Para a extração e a quantificação de proteínas totais foi utilizada a fração protéica contida no precipitado da extração dos carotenóides e descrito em CARVALHO et al. (2013) com algumas modificações. Foi solubilizada em tampão de suspensão de proteínas (TSP contendo Tris $1 \mathrm{M} \mathrm{pH} \mathrm{7,6,} \mathrm{NaCl} 5$ M, EDTA 0,5 M, Chaps 
100 mM, DTT 500 mM, Pefabloc 200 mM), seguindo de vortex, sônicação por 15 min., votex, aqueceu em banho maria $\left(80^{\circ} \mathrm{C}\right)$ até gelatinizar o amido e solubilizar as proteínas, vortex, centrifugado $\left(5000 \mathrm{rpm} / 4^{\circ} \mathrm{C} / 15 \mathrm{~min}\right.$.) coletou-se o sobrenadante para quantificação de proteínas totais foi feita pelo método de Bradford (BioRad microassay) utilizando-se $50 \mu \mathrm{L}$ da suspensão de proteínas solubilizadas. Valores de leitura da densidade ótica foram usados para estimar teor de proteínas em $\mathrm{mg} \mathrm{g}^{-1}$ de peso seco.

Os dados obtidos foram primeiramente submetidos à análise de variância individual e posteriormente à análise de variância conjunta com delineamento experimental de blocos casualizados. As médias dos caracteres foram agrupadas por meio do teste aglomerativo de SCOTT \& KNOTT (1974), a 5\% de probabilidade de erro. Todas as análises estatísticas foram realizadas com o auxílio do programa estatístico Genes (CRUZ, 2001).

\subsection{RESULTADOS E DISCUSSÃO}

Os resultados das análises de variância individuais revelaram a existência de diferenças significativas a $5 \%$ de probabilidade de erro entre os clones quanto aos caracteres quantitativos altura da planta, altura da primeira ramificação, peso da parte aérea sem a cepa, produtividade de raízes, porcentagem de amido nas raízes nas duas safras e tempo para a cocção em minutos somente na safra 2 (Tabela 1 e 2) e os caracteres bioquímicos teor de carotenóides totais nas raízes e teor de proteínas nas raízes (Tabela 2). Esses resultados indicam que os clones avaliados têm variabilidade para o desempenho agronômico e características bioquímicas, corroborando com os resultados obtidos para acessos de mandioca de mesa em áreas de Cerrado (VIEIRA et al., 2011b; FIALHO et al., 2009).

Os coeficientes de variação variaram de 3,01\% para o caractere tempo para a cocção na safra 2011/2012 a 10,20\% para o caráter produtividade de raízes na mesma safra, o que dá um indicativo da elevada precisão dos dados e controle dos efeitos ambientais dos experimentos (Tabelas 1 e 2). 
Tabela 1. Resumo da análise de variância individual e coeficiente de variação (CV\%) dos caracteres altura da primeira ramificação em metro (APR), altura da planta em metro (AP), peso da parte aérea sem a cepa em $\mathrm{Kg} \mathrm{ha}^{-1}$ (PPA), e porcentagem de amido nas raízes (AM) avaliados em treze genótipos de mandioca de mesa, nas safras 2010/2011 (S1) e 2011/2012 (S2). UnB/ Embrapa Cerrados, Brasília, DF, 2015.

\begin{tabular}{|c|c|c|c|c|c|c|c|c|c|}
\hline \multirow{3}{*}{$\mathrm{FV}$} & \multirow{3}{*}{ GL } & \multicolumn{8}{|c|}{$\mathrm{QM}$} \\
\hline & & \multicolumn{2}{|c|}{ APR } & \multicolumn{2}{|c|}{ AP } & \multicolumn{2}{|c|}{ PPA } & \multicolumn{2}{|c|}{ AM } \\
\hline & & S1 & $\mathrm{S} 2$ & $\mathrm{~S} 1$ & $\mathrm{~S} 2$ & S1 & $\mathrm{S} 2$ & S1 & $\mathrm{S} 2$ \\
\hline Genótipos (G) & 12 & $0,034^{*}$ & $0,068^{*}$ & $0,17^{*}$ & $0,12^{*}$ & 35623619 & $45898506^{*}$ & $14,21^{*}$ & $12,99^{*}$ \\
\hline Resíduo (R) & 24 & 0,002 & 0,002 & 0,01 & 0,012 & 3499880 & 2202142 & 0,86 & 0,91 \\
\hline Relação QM $(\mathrm{R})$ & & $1,($ & 00 & 1, & 20 & & & & 6 \\
\hline CV $(\%)$ & & 7,15 & 9,80 & 5,53 & 6,76 & 9,51 & 7,81 & 3,79 & 3,54 \\
\hline
\end{tabular}

Tabela 2. Resumo da análise de variância individual e coeficiente de variação (CV\%) dos caracteres produtividade de raízes em $\mathrm{Kg} \mathrm{ha}^{-1}$ (PR), tempo para a cocção em minutos (TC), teor de carotenoides totais nas raízes em $\mu \mathrm{g} \mathrm{g}^{-1}$ de massa seca (CT) e teor de proteínas nas raízes em $\mu \mathrm{g} \mathrm{g}^{-1}$ de massa seca (PT) avaliados em treze genótipos de mandioca de mesa, nas safras 2010/2011 (S1) e 2011/2012 (S2). UnB/ Embrapa Cerrados, Brasília, DF, 2015.

\begin{tabular}{|c|c|c|c|c|c|c|c|c|}
\hline \multirow{3}{*}{ FV } & \multirow{3}{*}{$\mathrm{GL}^{-}$} & \multicolumn{7}{|c|}{ QM } \\
\hline & & \multicolumn{2}{|c|}{ PR } & \multicolumn{2}{|r|}{$\mathrm{TC}$} & \multicolumn{2}{|c|}{ CT } & PT \\
\hline & & S1 & S2 & S1 & S2 & S1 & S2 & S2 \\
\hline$\overline{\text { Genótipos }(\mathrm{G})}$ & 12 & 102323549 & $100644943^{*}$ & - & $32,75^{\circ}$ & $31,26^{3}$ & 12,46 & $0,42^{*} 0,37^{*}$ \\
\hline Resíduo (R) & 24 & 3625601 & 9601717 & - & 0,62 & 0,36 & 0,27 & $0,0150,009$ \\
\hline \multirow{2}{*}{\multicolumn{2}{|c|}{$\operatorname{Relação~QM~}_{(\mathrm{R})}$}} & \multicolumn{2}{|c|}{2,65} & & - & \multicolumn{2}{|c|}{1,33} & 1,67 \\
\hline & & 8,55 & 10,20 & - & 3,01 & 5,53 & 5,48 & $5,91 \quad 4,65$ \\
\hline
\end{tabular}

"significativo a $5 \%$ de probabilidade de erro pelo teste $\mathrm{F}$.

A análise de variância conjunta apontou a existência de diferenças significativas a 5\% de probabilidade de erro entre as médias das safras 2010/2011 e 2011/2012 para altura da primeira ramificação, altura da planta, porcentagem de amido nas raízes, produtividade de raízes e teor de carotenoides totais nas raízes (Tabelas 3), indicando que a média desses caracteres foi influenciada pelo fator safra. Entretanto, o fator safra não influenciou significativamente, a 5\% de probabilidade de erro, a média dos caracteres peso da parte aérea sem a cepa e teor de proteínas nas raízes (Tabelas 3).

Dentre os caracteres estudados, foi detectada a presença de diferenças significativas a $5 \%$ de probabilidade de erro entre as médias dos genótipos nas duas safras para todos os caracteres aferidos (Tabelas 3), o que indica a presença de variação 
individual quanto ao fator safra no grupo de genótipos avaliados. Também foi detectada a presença de interação significativa a $5 \%$ de probabilidade de erro entre os fatores safra e genótipos para todos os caracteres, com exceção do caráter produtividade de raízes (Tabela 3). Essa interação significativa evidencia a necessidade da avaliação dos acessos por mais de um ano, na obtenção de uma estimativa segura da expressão final desses caracteres aferidos, corroborando o que foi relatado para mandioca por BORGES et al. (2002) e VIEIRA et al. (2012).

Os coeficientes de variação das análises de variância conjunta variaram de $3,66 \%$ para o caractere porcentagem de amido nas a 9,77\% para o caractere produtividade de raízes, indicando elevada precisão experimental (Tabela 3).

Tabela 3. Resumo da análise de variância conjunta, média, coeficiente de variação (CV\%) e coeficiente de determinação genotípica (b) dos caracteres altura da primeira ramificação em metro (APR), altura da planta em metro (AP), peso da parte aérea sem a cepa em $\mathrm{Kg} \mathrm{ha}^{-1}$ (PPA), porcentagem de amido nas raízes (AM) produtividade de raízes em $\mathrm{Kg} \mathrm{ha}^{-1}(\mathrm{PR})$, teor de carotenoides totais nas raízes em $\mu \mathrm{g} \mathrm{g}^{-1}$ de massa seca (CT) e teor de proteínas nas raízes em $\mu \mathrm{g} \mathrm{g}^{-1}$ de massa seca (PT) avaliados em treze genótipos de mandioca de mesa, nas safras 2010/2011 (S1) e 2011/2012 (S2). UnB/ Embrapa Cerrados, Brasília, DF, 2015.

\begin{tabular}{|c|c|c|c|c|c|c|c|c|}
\hline \multirow{2}{*}{$\mathrm{FV}$} & \multirow{2}{*}{ GL } & \multicolumn{7}{|c|}{$\mathrm{QM}$} \\
\hline & & APR & AP & PPA & AM & PR & CT & PT \\
\hline Blocos/Safra (B/S & 4 & 0,008 & 0,028 & 17843315 & 1,26 & 27412659 & 0,05 & 0,04 \\
\hline Genótipos (G) & 12 & $0,073^{*}$ & $0,19^{*}$ & $46057143^{*}$ & $23,15^{*}$ & $192373312^{*}$ & $39,23^{*}$ & $0,45^{*}$ \\
\hline Safras (S) & 1 & $0,39^{*}$ & $0,66^{*}$ & 9224017 & $115^{*}$ & $1281080355^{*}$ & ${ }^{*} 40,68^{*}$ & 0,08 \\
\hline $\mathrm{G} \times \mathrm{S}$ & 12 & $0,03^{*}$ & $0,109^{*}$ & $35464982^{*}$ & $4,06^{*}$ & 10595180 & $4,49^{*}$ & $0,33^{*}$ \\
\hline Resíduo (R) & 48 & 0,002 & 0,011 & 2851011 & 0,89 & 6613659 & 0,32 & 0,01 \\
\hline Total & 77 & & & & & & & \\
\hline Média & & 0,59 & 1,74 & 19332 & 25,72 & 26310 & 10,21 & 2,04 \\
\hline $\mathrm{CV}(\%)$ & & 8,32 & 6,12 & 8,73 & 3,66 & 9,77 & 5,52 & 5,34 \\
\hline
\end{tabular}

significativo a $5 \%$ de probabilidade de erro pelo teste $\mathrm{F}$.

Dentre os clones avaliados, os que apresentaram maiores médias quanto ao caractere altura da primeira ramificação (APR) na safra 2010/2011 foram os clones 259/08 e 273/08 e na safra 2011/2012 foi o clone 259/08 (Tabela 4). Para o caractere altura da planta (AP) na safra 2010/2011 os clones que apresentaram médias superiores foram 90/08, 272/08, 273/08, 497/08 e na safra 2011/2012 foram 259/08 e 450/08 (Tabela 4). Esses caracteres são importantes para a seleção de acessos por 
estabelecerem relação à facilidade de práticas culturais, disponibilidade de manivassementes para novos plantios, facilidade de plantio mecanizado e facilidade de colheita, sendo preferidos os acessos que apresentam maior altura da primeira ramificação ou que não apresentem ramificação e que apresentem elevada altura de planta (FUKUDA et al., 2002; VIEIRA et al., 2011b).

Para o peso da parte aérea (PPA), foi identificada a amplitude de variação de 14198 a $26059 \mathrm{~kg} \mathrm{ha}^{-1}$, tendo sido destacados quatro clones com médias superiores aos demais clones. São eles, os clones 94/08 e 272/08 na safra 2010/2011; 259/08 e 450/08 na safra 2011/2012 com $25602 \mathrm{Kg} \mathrm{ha}^{-1}, 26059 \mathrm{Kg} \mathrm{ha}^{-1}, 25656 \mathrm{Kg} \mathrm{ha}^{-1}$ e $25750 \mathrm{Kg} \mathrm{ha}^{-1}$, respectivamente (Tabela 4). Esta característica é importante por estar relacionada com o fornecimento de manivas-sementes para novos plantios, cobertura do solo e a utilização da parte aérea da mandioca como fonte de proteína na alimentação animal (SOUZA et al., 2011; AZEVEDO et al., 2006).

Quanto ao caractere porcentagem de amido nas raízes (AM) na safra 2010/2011 os clones que apresentaram médias superiores aos demais foram os clones 26/08 e 450/08, com respectivamente $27,02 \%$ e $28,37 \%$. Na safra 2011/2012, foi o clone 259/08 e a testemunha IAC 576-70, com respectivamente $31,08 \%$ e $30,67 \%$ (Tabela 4). Essa característica, apesar de ser mais importante na seleção de materiais para a indústria, tem importância no melhoramento de mandioca de mesa, quando se pensa no aproveitamento das raízes na produção de farinha e fécula. 
Tabela 4. Médias dos caracteres altura da primeira ramificação em metro (APR), altura da planta em metro (AP), peso da parte aérea sem a cepa em $\mathrm{Kg} \mathrm{ha}^{-1}$ (PPA) e porcentagem de amido nas raízes (AM) avaliados em treze clones de mandioca de mesa, nas safras 2010/2011 (S1) e 2011/2012 (S2). UnB/ Embrapa Cerrados, Brasília, DF, 2015.

\begin{tabular}{|c|c|c|c|c|c|c|c|c|}
\hline \multirow{2}{*}{ Genótipos } & APR & APR & $\mathrm{AP}$ & $\mathrm{AP}$ & PPA & PPA & AM & $\mathrm{AM}$ \\
\hline & S1 & S2 & S1 & S2 & S1 & S2 & S1 & S2 \\
\hline Clone 26 & $0,48 \mathrm{Ad}^{*}$ & $0,47 \mathrm{Ad}$ & $1,43 \mathrm{Ad}$ & $1,53 \mathrm{Ab}$ & $16689 \mathrm{Ad}$ & $15726 \mathrm{Ad}$ & $27,02 \mathrm{Aa}$ & $28,56 \mathrm{Ab}$ \\
\hline Clone 90 & $0,68 \mathrm{Ab}$ & $0,57 \mathrm{Bc}$ & $2,00 \mathrm{Aa}$ & $1,40 \mathrm{Bc}$ & $20840 \mathrm{Ab}$ & $23028 \mathrm{Ab}$ & $22,37 \mathrm{Bd}$ & $24,97 \mathrm{Ac}$ \\
\hline Clone 91 & $0,70 \mathrm{Ab}$ & $0,48 \mathrm{Bd}$ & $1,67 \mathrm{Ac}$ & $1,47 \mathrm{Bc}$ & $14907 \mathrm{Ad}$ & $14198 \mathrm{Ad}$ & $23,88 \mathrm{Bc}$ & $26,42 \mathrm{Ac}$ \\
\hline Clone 94 & $0,53 \mathrm{Ad}$ & $0,47 \mathrm{Ad}$ & $1,87 \mathrm{Ab}$ & $1,62 \mathrm{Bb}$ & $25602 \mathrm{Aa}$ & $17493 \mathrm{Bc}$ & $21,00 \mathrm{Bd}$ & $24,88 \mathrm{Ac}$ \\
\hline Clone 215 & $0,58 \mathrm{Ac}$ & $0,43 \mathrm{Bd}$ & $1,60 \mathrm{Ac}$ & $1,60 \mathrm{Ab}$ & $16834 \mathrm{Ad}$ & $18201 \mathrm{Ac}$ & $24,48 \mathrm{Ac}$ & $26,00 \mathrm{Ac}$ \\
\hline Clone 246 & $0,58 \mathrm{Ac}$ & $0,63 \mathrm{Ab}$ & $1,73 \mathrm{Ab}$ & $1,63 \mathrm{Ab}$ & $18542 \mathrm{Ac}$ & $14521 \mathrm{Bd}$ & $21,87 \mathrm{Bd}$ & $26,76 \mathrm{Ac}$ \\
\hline Clone 259 & $0,82 \mathrm{Ba}$ & $0,90 \mathrm{Aa}$ & $1,80 \mathrm{Ab}$ & 1,93 Aa & $16944 \mathrm{Bd}$ & $25656 \mathrm{Aa}$ & $26,00 \mathrm{Bb}$ & $31,08 \mathrm{Aa}$ \\
\hline Clone 272 & $0,60 \mathrm{Ac}$ & $0,42 \mathrm{Be}$ & $2,13 \mathrm{Aa}$ & $1,53 \mathrm{Bb}$ & $26059 \mathrm{Aa}$ & $18017 \mathrm{Bc}$ & $25,37 \mathrm{Ab}$ & $25,81 \mathrm{Ac}$ \\
\hline Clone 273 & $0,85 \mathrm{Aa}$ & $0,48 \mathrm{Bd}$ & $2,20 \mathrm{Aa}$ & $1,90 \mathrm{Ba}$ & $21256 \mathrm{Ab}$ & $20444 \mathrm{Ab}$ & $23,74 \mathrm{Bc}$ & $26,35 \mathrm{Ac}$ \\
\hline Clone 446 & $0,72 \mathrm{Ab}$ & $0,37 \mathrm{Be}$ & $1,67 \mathrm{Ac}$ & $1,58 \mathrm{Ab}$ & $16523 \mathrm{Bd}$ & $20694 \mathrm{Ab}$ & $24,76 \mathrm{Ac}$ & $25,72 \mathrm{Ac}$ \\
\hline Clone 450 & $0,67 \mathrm{Ab}$ & $0,47 \mathrm{Bd}$ & $1,67 \mathrm{Bc}$ & 1,90 Aa & $21679 \mathrm{Bb}$ & $25750 \mathrm{Aa}$ & $28,37 \mathrm{Aa}$ & $28,14 \mathrm{Ab}$ \\
\hline Clone 497 & $0,73 \mathrm{Ab}$ & $0,68 \mathrm{Ab}$ & $2,20 \mathrm{Aa}$ & $1,97 \mathrm{Ba}$ & $20260 \mathrm{Ab}$ & $17757 \mathrm{Ac}$ & $22,96 \mathrm{Bd}$ & $24,83 \mathrm{Ac}$ \\
\hline IAC 576-70 & $0,60 \mathrm{Ac}$ & $0,33 \mathrm{Be}$ & $1,90 \mathrm{Ab}$ & $1,40 \mathrm{Bc}$ & $19645 \mathrm{Ac}$ & $15354 \mathrm{Bd}$ & $26,82 \mathrm{Ba}$ & $30,67 \mathrm{Aa}$ \\
\hline Ideótipo ${ }^{* * *}$ & 0,85 & 0,90 & 2,20 & 1,97 & 26059 & 25750 & 28,37 & 31,08 \\
\hline Média & $0,66 \mathrm{~A}$ & $0,52 \mathrm{~B}$ & $1,84 \mathrm{~A}$ & $1,65 \mathrm{~B}$ & $19675 \mathrm{~A}$ & $18988 \mathrm{~A}$ & $24,51 \mathrm{~B}$ & $26,94 \mathrm{~A}$ \\
\hline Amplitude $^{\#}$ & 0,37 & 0,57 & 0,77 & 0,57 & 11152 & 11552 & 7,38 & 6,25 \\
\hline
\end{tabular}

O teste de agrupamento de médias revelou que o clone 215/08 apresentou média superior aos demais para o caractere produtividade de raízes (PR) em ambas as safras, com produtividade de $32.795 \mathrm{t} \mathrm{ha}^{-1}$ e $36.587 \mathrm{t} \mathrm{ha}^{-1}$, respectivamente. Na safra 2011/2012 outros clones também apresentaram médias agrupadas com a média do clone 215/08, sendo eles os clones 272/08, 446/08, 497/08 e a testemunha IAC 576-70 (Tabela 5). A produtividade de raízes é um dos caracteres mais importantes para a seleção de genótipos de mandioca de mesa, em função de ser um dos fatores relacionados ao potencial de rendimento de raízes do clone. Todos os clones apresentaram produção de raízes superior à média obtida na região do Cerrado de $13 \mathrm{t} \mathrm{ha}^{-1}$ (IBGE, 2011).

O tempo para a cocção não foi considerado na análise de variância da safra 2010/2011 uma vez que nenhum genótipo, incluindo a variedade recomendada para o cultivo na região do Distrito Federal e entorno utilizada como testemunha (IAC 57670), apresentou tempo inferior a 30 minutos, devido a problemas climáticos e ao percevejo de renda que ocorreram durante essa safra agrícola o que contribuiu para a 
antecipação da rebrota dos materiais. Na safra 2011/2012 todos os clones apresentaram tempo para a cocção inferior a 30 minutos, destacando-se o genótipo que apresentou média inferior aos demais que foi a testemunha IAC 576-70. Com este resultado, verificou-se indica que as raízes dos clones avaliados têm qualidade culinária para a comercialização como mandioca de mesa. Além do tempo para cocção das raízes de reserva inferior a 30 minutos, as raízes dos clones selecionados devem apresentar massa cozida uniforme, sem fibras e com consistência plástica e moldável (FUKUDA et al., 2002), características observadas nos clones elites avaliados nesse trabalho.

Dentre os clones avaliados, apenas o clone 94/08 teve média superior aos demais para teor de carotenóides totais nas raízes, em ambas as safras 2010/2011 e 2011/2012, resultado este que representou o dobro da quantidade de carotenóides totais em comparação com a testemunha. Entre os clones estudados na safra 1, aqueles com coloração da polpa das raízes amarelada (246/08, 91/08, 272/08, 215/08 e 497/08) foram os que tiveram as maiores médias de carotenóides totais nas raízes com 15,13, $13,85,12,17,12,05,11,86 \mu \mathrm{g} \mathrm{g}^{-1}$ de massa seca, respectivamente. Na safra 2, os clones com maiores médias foram 215/08, 246/08 e 272/08 com 11,35, 11,13 e 10,89 $\mu \mathrm{g} \mathrm{g}^{-1}$ de massa seca, respectivamente (Tabela 5). Resultado semelhante foi relatado por SILVA et al. (2014) após analisar 13 acessos de mandioca do Banco Regional de Germoplasma de Mandioca do Cerrado (BGMC), em que as médias de teor de carotenóides nas raízes foram superiores a $10 \mu \mathrm{g} \mathrm{g}^{-1}$. Já MEZETTE et al. (2009), ao analisarem 13 clones de mandioca do Programa de Melhoramento Genético de Mandioca de Mesa do IAC, relataram valores de carotenóides variando de 3,30 a $11,08 \mu \mathrm{g} \mathrm{g}^{-1}$. O teor de carotenoides totais pode ser considerado um bom indicador do teor de $\beta$-caroteno em raízes de reserva de mandioca, uma vez que estudos vêm revelando que, em média, 70\% do teor de carotenóides totais correspondem ao $\beta$-caroteno (MEZETTE et al. 2009; CARVALHO et al., 2012).

Para teor de proteínas nas raízes (PT) na safra 2010/2011, os clones que tiveram médias superiores aos demais foram os clones 90/08 e 91/08 com 2,61 e 2,60 $\mu \mathrm{g} \mathrm{g}^{-1}$ de massa seca respectivamente. Na safra 2011/2012, os clones 26/08 e 90/08 se destacaram com 2,54 e 2,43 $\mu \mathrm{g} \mathrm{g}^{-1}$ de massa seca, respectivamente (Tabela 5). Em trabalho relatado por CARVALHO et al. (2013), após analisar 29 variedades locais do Banco de Germoplasma da Embrapa Recursos Genéticos e Biotecnologia, foram observados teores de proteínas variando de 0,27 (cv. IAC 12.829) a $8.0 \mathrm{mg} \mathrm{g}^{-1}$ (espécie nativa CAS006). Entretanto, ainda existem poucos relatos na literatura sobre o teor de 
proteínas encontradas em raízes de reserva de mandioca, com vista à utilização no melhoramento genético.

O teor de ácido cianídrico $(\mathrm{HCN})$ nas raízes de reserva de mandioca, em todos os clones, evidenciaram quantidades inferiores a $100 \mathrm{mg} \mathrm{kg}^{-1}$ (Tabela 5), portanto sendo próprios para a comercialização como vegetal fresco in natura. Segundo BORGES et al. (2002), a identificação de variedades de mandioca com baixos teores de ácido cianídrico na polpa crua das raízes é necessária para aumentar a segurança alimentar e diminuir os riscos de intoxicação dos consumidores.

Tabela 5. Comparação de médias dos caracteres produtividade de raízes em $\mathrm{kg} \mathrm{ha}^{-1}$ (PR), tempo para a cocção em minutos (TC), teor de carotenoides totais nas raízes em $\mu \mathrm{g} \mathrm{g}^{-1}$ de massa seca (CT), teor de proteínas nas raízes em $\mu \mathrm{g} \mathrm{g}^{-1}$ de massa seca (PT) e o teor de ácido cianídrico nas raízes em $\mathrm{mg} \mathrm{Kg}^{-1}(\mathrm{HCN})$, avaliados em treze genótipos de mandioca de mesa, nas safras 2010/2011 (S1) e 2011/2012 (S2). UnB/ Embrapa Cerrados, Brasília, DF, 2015.

\begin{tabular}{|c|c|c|c|c|c|c|c|c|}
\hline \multirow{2}{*}{ Acessos } & PR & PR & $\mathrm{TC}$ & $\mathrm{CT}$ & $\mathrm{CT}$ & PT & PT & $\mathrm{HCN}$ \\
\hline & S1 & $\mathrm{S} 2$ & $\mathrm{~S} 2$ & $\mathrm{~S} 1$ & $\mathrm{~S} 2$ & S1 & $\mathrm{S} 2$ & $\mathrm{~S} 1$ \\
\hline Clone 26 & $13947 \mathrm{Be}^{*}$ & $18833 \mathrm{Ad}$ & $21,33 \mathrm{~d}$ & $7,62 \mathrm{Bh}$ & $8,98 \mathrm{Ad}$ & $1,88 \mathrm{Bd}$ & $2,54 \mathrm{Aa}$ & $25-40$ \\
\hline Clone 90 & $17419 \mathrm{Bd}$ & $29726 \mathrm{Ab}$ & $30,00 \mathrm{a}$ & $10,89 \mathrm{Ae}$ & $9,60 \mathrm{Bd}$ & $2,61 \mathrm{Aa}$ & $2,43 \mathrm{Aa}$ & $40-60$ \\
\hline Clone 91 & $19103 \mathrm{Bd}$ & $27191 \mathrm{Ac}$ & $29,67 \mathrm{a}$ & $13,85 \mathrm{Ac}$ & $10,41 \mathrm{Bc}$ & $2,60 \mathrm{Aa}$ & $1,37 \mathrm{Bd}$ & $25-40$ \\
\hline Clone 94 & $13405 \mathrm{Be}$ & $23114 \mathrm{Ac}$ & $29,33 \mathrm{a}$ & $16,95 \mathrm{Aa}$ & $12,13 \mathrm{Ba}$ & $2,40 \mathrm{Ab}$ & $1,90 \mathrm{Bc}$ & $25-40$ \\
\hline Clone 215 & $32795 \mathrm{Aa}$ & $36587 \mathrm{Aa}$ & $25,33 \mathrm{~b}$ & $12,05 \mathrm{Ad}$ & $11,35 \mathrm{Ab}$ & $2,35 \mathrm{Ab}$ & $2,26 \mathrm{Ab}$ & $25-40$ \\
\hline Clone 246 & $17451 \mathrm{Bd}$ & $25434 \mathrm{Ac}$ & $25.67 \mathrm{~b}$ & $15,13 \mathrm{Ab}$ & $11,13 \mathrm{Bb}$ & $2,40 \mathrm{Ab}$ & $2,19 \mathrm{Bb}$ & $40-60$ \\
\hline Clone 259 & $21382 \mathrm{Bd}$ & $26906 \mathrm{Ac}$ & $23,67 \mathrm{c}$ & $6,47 \mathrm{Ai}$ & $5,47 \mathrm{Bf}$ & $1,50 \mathrm{Af}$ & $1,49 \mathrm{Ad}$ & $40-60$ \\
\hline Clone 272 & $25324 \mathrm{Bc}$ & $35510 \mathrm{Aa}$ & $26,33 \mathrm{~b}$ & $12,17 \mathrm{Ad}$ & $10,89 \mathrm{Bb}$ & $1,73 \mathrm{Ae}$ & $1,75 \mathrm{Ac}$ & $25-40$ \\
\hline Clone 273 & $23310 \mathrm{Bc}$ & $32958 \mathrm{Ab}$ & $29,00 \mathrm{a}$ & $10,96 \mathrm{Ae}$ & $10,43 \mathrm{Ac}$ & $1,57 \mathrm{Bf}$ & $1,87 \mathrm{Ac}$ & $25-40$ \\
\hline Clone 446 & $28692 \mathrm{Bb}$ & $37253 \mathrm{Aa}$ & $25,67 \mathrm{~b}$ & $8,18 \mathrm{Ag}$ & 7,28 Ae & $1,83 \mathrm{Bd}$ & $2,22 \mathrm{Ab}$ & $25-40$ \\
\hline Clone 450 & $25926 \mathrm{Bc}$ & $30590 \mathrm{Ab}$ & $25,33 \mathrm{~b}$ & $9,26 \mathrm{Af}$ & $9,64 \mathrm{Ad}$ & $1,91 \mathrm{Bd}$ & $2,24 \mathrm{Ab}$ & $40-60$ \\
\hline Clone 497 & $27506 \mathrm{Bb}$ & $36316 \mathrm{Aa}$ & $29,67 \mathrm{a}$ & $11,86 \mathrm{Ad}$ & $9,89 \mathrm{Bd}$ & $2,01 \mathrm{Ac}$ & $1,97 \mathrm{Ac}$ & $25-40$ \\
\hline IAC 576-70 & $23085 \mathrm{Bc}$ & $34295 \mathrm{Aa}$ & 19,67 e & $6,71 \mathrm{Ai}$ & $6,10 \mathrm{Af}$ & $2,12 \mathrm{Ac}$ & $1,83 \mathrm{Bc}$ & $25-40$ \\
\hline Média & $22257 \mathrm{~B}$ & $30363 \mathrm{~A}$ & 26,21 & $10,93 \mathrm{~A}$ & $9,49 \mathrm{~B}$ & $2,07 \mathrm{~A}$ & $2,00 \mathrm{~A}$ & \\
\hline Amplitude & 19390 & 18420 & 10,33 & 10,48 & 6,67 & 1,11 & 1,17 & \\
\hline
\end{tabular}

Com base nos resultados obtidos, é possível afirmar que, no grupo dos clones avaliados, alguns têm desempenho agronômico e bioquímico que permitem o seu cultivo de forma comercial na região do Cerrado do Brasil. Nesse sentido, destacam-se como possíveis clones para o plantio comercial da cultura, aqueles com boa 
produtividade e com elevado teor de carotenóides como 215/08, 446/08 e 497/08. Dentre os clones avaliados, existem aqueles com grande potencial para utilização como genitores no melhoramento da cultura em cruzamentos com constituições genéticas adaptadas as condições do Cerrado do Brasil, visando ao aumento dos teores de $\beta$ caroteno em raízes de reserva de mandioca.

\subsection{CONCLUSÕES}

Entre os clones avaliados, alguns apresentaram destaque no desempenho agronômico com base nos caracteres altura da primeira ramificação (273/08 e 259/08), altura da planta (90/08, 272/08, 273/08, 497/08, 259/08 e 450/08), peso da parte aérea sem a cepa (94/08 e 272/08), porcentagem de amido nas raízes (26/08, 272/08, 259/08 e 450/08) e produtividade de raízes (215/08). Em relação ao tempo de cocção na safra 2011/2012, todos os clones tiveram tempo de cozimento inferior a 30 minutos.

Em relação ao teor de carotenóides totais nas raízes, os clones que se destacaram foram 91/08, 94/08, 215/08, 246/08, 272/08 e 497/08. Em relação ao teor de proteínas nas raízes os clones 26/08, 90/08 e 91/08foram os melhores. Os teores de HCN nas raízes de reserva de mandioca foram inferiores a $100 \mathrm{mg} \mathrm{Kg}^{-1} \mathrm{em}$ todos os clones avaliados.

Foi possível identificar clones elite com alto teor de carotenóides totais nas raízes. Estes clones têm grande potencial para utilização direta pelos produtores e/ou para a utilização como genitores em programas de melhoramento genético de mandioca de mesa. 


\subsection{REFERÊNCIAS BIBLIOGRÁFICAS}

AZEVEDO, E.B. NORNBERG, J.L.; KESSLER, G.B.; DAVID, D.B.; FALKENBERG, J. R.; CHIELLE, Z.G. Silagem da parte aérea de cultivares de mandioca. Ciência Rural, v.36, p. 1902-1908, 2006.

BORGES, M.F. FUKUDA, W.M.G.; ROSSETTI, A.G. Avaliação de variedades de mandioca para consumo humano. Pesquisa Agropecuária Brasileira, v.37, p.15591565, 2002. Disponível em: 22 nov. 2013. doi: 10.1590/S0100-204X2002001100006.

CARVALHO, L.J.C.B.; ALMEIDA, J., D. de; ANDERSON, J. V.; VIEIRA, E. A.; CHEN, S.; SOUZA, C. R. B. de; FUHRMANN, E.; SILVA, J. P. Da. Studies on variation of carotenoid-proteins content in cassava (Manihot esculenta Crantz) storage root reveal implications for breeding and the use of induced mutations. Plant Mutation Report (accepted). 2013.

CARVALHO, L. J. C. B.; LIPOLIS, J. ; CHEN, S.; SOUZA, C. R. B.; VIEIRA, E.A.; JAMES, V. A. Characterization of carotenoid-protein complexes and gene expression analysis associated with carotenoid sequestration in pigmented cassava (Manihot Esculenta Crantz) storage root. The Open Biochemistry Journal, v. 6, p. 116-130, 2012. doi: 10.2174/1874091X01206010116.

CHÁVEZ, A.L.; SÁNCHEZ, T.; JARAMILLO, G.; BEDOYA, J.M.; ECHEVERRY, J.; BOLANOS, E.A.; CEBALLOS, H.; IGLESIAS, C.A.. Variation of quality traits in cassava roots evaluated in landraces and improved clones. Euphytica, v. 143, n. 01, p. 125-133, 2005.

COCK, J. H. Cassava: A basic energy source in the tropics. In "Cassava: Research, production and utilization". Eds. J. H. COCK e J. A. Reyes. UNDT CIAT. Cali, Colombia.1985.

CRUZ, C. D. Programa genes: aplicativo computacional em genética e estatística. Viçosa: UFV, 2001. 648 p.

BORGES, M. F.; FUKUDA, W. M. G.; ROSSETTI, A. G. Avaliação de variedades de mandioca para consumo humano. Pesquisa Agropecuária Brasileira, v.37, p.1559$1565,2002$.

FIALHO, J. F.; SOUSA, D. M. G.; VIEIRA, E. A. Manejo do solo no cultivo de mandioca. In: FIALHO, J.F.; VIEIRA, E. A. (Eds.). Mandioca no Cerrado: orientações técnicas. 2. ed. Planaltina: Embrapa Cerrados, 2013. p. 39-60. 
FIALHO, J. F.; VIEIRA, E. A. Manejo e tratos culturais da mandioca. In: FIALHO, J.F.; VIEIRA, E. A. (Eds.). Mandioca no Cerrado: orientações técnicas. 2. ed. Planaltina: Embrapa Cerrados, 2013. p. 61-88.

FIALHO, J.F.; VIEIRA, E.A.; SILVA, M.S.; PAULA-MORAES, S.V.; FUKUDA, W.M.G.; SANTOS FILHO, M.O.S.; SILVA, K.N. Desempenho de variedades de mandioca de mesa no Distrito Federal. Revista Brasileira Agrociência, v.15, p.31-35, 2009.

FUKUDA, W. M. G.; SILVA, S. O.; IGLESIAS, C. Cassava breeding. Crop Breeding and Applied Biotechnology, v.2, n.4, p. 617-638, 2002.

GROSMANN, J.; FREITAS, A. G. Determinação do teor de matéria seca pelo método do peso específico em raízes de mandioca. Revista Agronômica, v.14, p.75-80, 1950.

Instituto Brasileiro de Geografia e Estatística (2011). Sistema IBGE de recuperação automática - SIDRA. 2011. Disponível em: 〈http://www.sidra.ibge.gov.br/>. Acesso em: 11 mar. 2014.

MEZETTE, T. F. et al. Seleção de clones-elite de mandioca de mesa visando a características agronômicas, tecnológicas e químicas. Bragantia, v. 68, n. 03, p. 601609, 2009.

NASSAR, N.M.A. Wild and indigenous cassava, Manihot esculenta Crantz diversity: An untapped genetic resource. Genetic Resource and Crop Evolution, Netherlands, v. 54, p. 1523-1530, 2007.

RODRIGUEZ-AMAYA, D. B.; KIMURA, M. HarvestPlus handbook for caratenoid analysis. Washington: IFPRI, 2004. 58p.

SCOTT, A. J.; KNOTT, M. A. A cluster analysis methods for grouping means in the analysis of variance. Biometrics, v.30, p.507-512, 1974.

SHAMI, N.J.I.E.; MOREIRA, E.A.M. Licopeno como agente antioxidante. Revista de Nutrição, v.17, p.227-236, 2004. Disponível em: 20 abr. 2013. doi: 10.1590/S141552732004000200009

SILVA, K. N. ; VIEIRA, E. A.; FIALHO, J. de F.; CARVALHO, L. J. C. B.; SILVA, M. S. Potencial agronômico e teor de carotenoides em raízes de reserva de mandioca. Ciência Rural (UFSM. Impresso), v. 44, p. 1348-1354, 2014.

SOUZA, A.S.; ROCHA JUNIOR, V.R.; MOTA, A.D.S.; PALMA, M.N.N.; FRANCO, M.O.; FRANCO, M.O.; DUTRA, E.S.; SANTOS, C.C.R.; AGUIAR, A.C.R.; OLIVEIRA, C.R. Valor nutricional de frações da parte aérea de quatro variedades de mandioca. Revista Brasileira de Saúde e produção Animal, v. 12, p. 441-455, 2011. 
SOUZA, W.A. de; VILAS BOAS, O.G. da C. A deficiência de vitamina A no Brasil: um panorama. Revista Panamericana de Salud Pública, v. 12, n. 3, p. 173-179, 2002. VIEIRA, E. A.; FIALHO, J. F.; FALEIRO, F. G.; BELLON, G.; FONSECA, K. G.; CARVAlHO. L. J. C. B.; SILVA, M. S.; PAUlA-MORAES, S. V.; OLIVEIRA, C. M.; DENKE, M. L. Characterization of sweet cassava acessions based on molecular, quantitative and qualitative data. Crop Breeding and Applied Biotechnology, v.11, n.3, p.232-240, 2011a.

VIEIRA, E.A.; FIALHO, J.F.; FALEIRO, F.G.; BELLON, G.; FONSECA, K.G.; SILVA, M.S.; PAULA-MORAES, S.V.; CARVALHO. L.J.C.B. Caracterização fenotípica e molecular de acessos de mandioca de indústria com potencial de adaptação às condições do cerrado do Brasil Central. Semina: Ciências Agrárias, v.34, p.567$582,2013$.

VIEIRA, E.A.; FIALHO, J. de F.; FALEIRO, F.G.; BELLON, G.; SILVA, M.S. Caracterização molecular de acessos de mandioca biofortifi cados com potencial de uso no melhoramento genético. Revista Ciência Agronômica, v.42, p.457-463, 2011b. Disponível em: 15 abr. 2013. doi: 10.1590/S1806-66902011000200027.

VIEIRA, E.A. ; FIALHO, J. de F.; SILVA, M. S. ; FUKUDA, W. M. G.; FALEIRO, F. G. Variabilidade genética do banco de germoplasma de mandioca da Embrapa Cerrados acessada por meio de descritores morfológicos. Científica, v. 36, p. 56-67, 2008.

WELCH, R. M.; GRAHAN, R. D. Breeding crops for enhanced micronutrient content. Plant and Soil, v. 245, n. 01, p. 205-214, 2002.

WILLIAMS, H.J.; EDWARDS, T.G. Estimation of cyanide with alkaline picrate. Journal of the Science of Food and Agriculture, v.31, p.15-22, 1980. Disponível em: 15 out. 2013. doi: 0.1002/jsfa.2740310104. 
CAPÍTULO 3. CARACTERES MORFOLÓGICOS DE CLONES ELITE DE MANDIOCA DE MESA COM POLPA ROSADA BIOFORTIFICADA

CHAPTER 3. MORPHOLOGICAL CHARACTERS IN SWEET CASSAVA ELITE CLONES WITH BIOFORTIFIED PINKISH PULP 


\section{RESUMO}

A cultura da mandioca (Manihot esculenta Crantz) é muito importante em países em desenvolvimento, principalmente em função da sua rusticidade e da capacidade que apresenta de produzir razoavemente bem em condições em que outras culturas não sobreviveriam. Tal habilidade advém de a espécie ser naturalmente tolerante a solos ácidos e à seca, e ao mesmo tempo oferecer uma flexibilidade de colheita aos produtores. Este trabalho teve como objetivo caracterizar por meio de descritores morfológicos, clones elite de mandioca de mesa rosada biofortificadas em processo de seleção pelo Programa de Melhoramento de Mandioca realizado na Embrapa Cerrados. Foram caracterizados 8 clones de mandioca, em comparação com a variedade testemunha IAC 576-70, avaliados em experimentos conduzidos na Embrapa Cerrados por duas safras. Foram obtidos 40 descritores morfológicos qualitativos para cada clone. Com base na distribuição de frequência dos genótipos nas diferentes classes fenotípicas foi calculado o coeficiente de entropia para cada descritor. A matriz de dissimilaridade genética entre os clones foi calculada com base no coeficiente de coincidência simples das classes fenotípicas e a partir dessa matriz, foi realizada a análise de agrupamento via dendrograma. Houve diferenças morfológicas entre os clones, demostrando que nenhum par de genótipos apresentou $100 \%$ de similaridade. O fator ano/safra não influenciou a expressão fenotípica dos caracteres aferidos. O coeficiente cofenético revelou elevado ajuste entre a representação gráfica via dendrograma $(r=0,92)$ e a matriz de dissimilaridade genética. Entre os caracteres aferidos, os que apresentaram maior entropia foram à cor do disco, forma do lóbulo central e cor do pecíolo. Entre os clones avaliados, verificou-se alguns com potencial para recomendação para cultivo comercial com base nos caracteres morfológicos desejáveis do ponto de vista agronômico.

Palavras-chaves: Manihot esculenta Crantz, melhorameto genético, caracteres morfológicos, biofortificação, recursos genéticos 


\begin{abstract}
The culture of cassava (Manihot esculenta Crantz) is very important in developing countries, mainly due to its hardiness and ability that has to produce reasonably well in conditions where other crops would not survive. This ability comes from the species is naturally tolerant to acid soils and drought, while offering a harvest of flexibility to producers. This study aimed to characterize by morphological clones elite biofortified pinkish edible cassava descriptors in the process of selection for cassava improvement program carried out at Embrapa Cerrado. They were characterized 8 cassava clones were characterized, in comparison with the control variety IAC 576-70, evaluated in experiments conducted at Embrapa Cerrado for two crop seasons. There were obtained 40 qualitative morphological descriptors for each clone. Based on the frequency distribution of the different genotypes phenotypic classes were calculated the entropy coefficient for each descriptor. The matrix of genetic divergence between the clones was calculated based on the coincidence factor of phenotypic classes and from this matrix was carried out via cluster analysis dendrogram. There was morphological differences among clones, showing that no two genotypes showed $100 \%$ similarity. The year / crop factor did not influence the phenotypic expression of measured characters. The cofenetic coefficient revealed high fit between the graphical representation via dendrogram $(r=0.92)$ and the genetic dissimilarity matrix. Among the measured characters, those with the highest entropy were the disc color, the central lobe shape and petiole color. Among clones, there was potential for some with recommendation for commercial cultivation based on the desirable morphological characters from an agricultural point of view.
\end{abstract}

Key words: Manihot esculenta Crantz, genetic breeding, characterize morphological, biofortified, genetic resources 


\subsection{INTRODUÇÃO}

Originária da América do Sul, a mandioca (Manihot esculenta Crantz) constitui um dos principais alimentos energéticos para mais de 700 milhões de pessoas, principalmente nos países em desenvolvimento. Mais de 100 países produzem mandioca, sendo que o Brasil participa com, aproximadamente $10 \%$ da produção mundial, sendo o segundo maior produtor do mundo. A produção mundial da mandioca foi estimada pela FAO (2011) em 257 milhões de toneladas de raízes e segundo o IBGE (2013), a produção nacional dessa cultura foi de 23 milhões de toneladas em 2012.

A mandioca sempre foi cultivada em razão de suas raízes de reservas ricas em amido, porém pobres em proteínas e vitaminas. Entretanto, nos últimos anos, os programas de melhoramento genético de mandioca de mesa estão focando no desenvolvimento de variedades biofortificadas que incluem, além das características desejadas, a presença de carotenoides como $\beta$-caroteno nas raízes de coloração amarela (MEZETTE et al., 2009; CARVALHO et al., 2012) e licopeno nas raízes de coloração rosada (CARVALHO et al., 2011). Algumas das principais fontes de carotenóides são cenouras e aboboras ( $\alpha$ e $\beta$-caroteno), tomates e produtos derivados, como extrato, polpa e molhos (licopeno) e espinafre (luteína). O licopeno aparece atualmente como um dos mais potentes antioxidantes, sendo sugerido na prevenção da carcinogênese e aterogênese por proteger moléculas como lipídios, lipoproteínas de baixa densidade (LDL), proteínas e DNA (SHAMI \& MOREIRA, 2004).

Na região do Distrito Federal e entorno, trabalhos de pesquisa demonstram que a cultura da mandioca apresenta grande potencial de expansão, uma vez que existe mercado (AGUIAR et al., 2005), a lucratividade é elevada e os produtores tem muita experiência com o sistema de produção. Apesar desse potencial, SOUZA \& FIALHO (2003) apontam como principal causa da baixa produtividade na região do Cerrado o uso de cultivares não melhoradas, suscetíveis à bacteriose (Xantomonas axonopodis pv. manihotis), ao superbrotamento (fitoplasma de espécie ainda desconhecida), ácaros (Mononychellus tanajoa Bondar, 1938) e ao percevejo-de-renda (Vatiga illudens Drake, 1922), bem como, o baixo potencial produtivo por não serem adaptadas a solos de baixa fertilidade e com elevado teor de alumínio. Além disso, o cultivo da mandioca na região pode ser considerado como um sistema arcaico de produção e na sua grande maioria constituído por variedades tradicionais, que não passaram por um processo de melhoramento genético (AGUIAR et al., 2005). Apesar da região do Cerrado ser uma 
das mais indicadas para a produção da cultura no país, a produtividade média de raízes é de apenas $13 \mathrm{t} \mathrm{ha}^{-1}$, contribuindo com apenas $10 \%$ da produção nacional (SOUZA \& FIALHO, 2003).

A obtenção e a caracterização agronômica de clones com elevada capacidade de produção, portadores de características agronômicas superiores e aptos a substituírem as cultivares tradicionais, são meios utilizados para aumentar o rendimento da cultura (FUKUDA, 1999). A caracterização morfológica por meio de descritores categóricos é importante para a caracterização e diferenciação dos genótipos para fins de proteção de cultivares e também para estudos de variabilidade genética, possibilitando assim o desenvolvimento e a disponibilização de genótipos superiores de mandioca de mesa para os produtores e consumidores. Dessa forma, neste trabalho, objetivou-se caracterizar, por meio de descritores morfológicos, clones elite de mandioca de mesa rosada biofortificadas selecionadas em condições do Cerrado do Brasil Central.

\subsection{MATERIAL E MÉTODOS}

O trabalho foi conduzido no campo experimental e no Laboratório de Raízes e Tubérculos da Embrapa Cerrados (CPAC), em Planaltina-DF, entre outubro de 2010 e outubro de 2011 e entre novembro de 2011 e novembro de 2012.

Para a realização do estudo foram caracterizados oito clones elite de mandioca de mesa com polpa rosada (clone 341/08, clone 345/08, clone 378/08, clone 387/08, clone 390/08, clone 395/08, clone 406/08, clone 413/08) selecionados para as condições do Cerrado (Tabela 1), sendo utilizada como testemunha a variedade de mandioca de mesa IAC 576-70, conhecida popularmente na região do Cerrado como Japonesinha, que no Banco de Germoplasma de Mandioca do Cerrado (BGMC) está identificada como BGMC 753 e que é indicada para o cultivo na região (FIALHO et al., 2009). 
Tabela 1. Relação dos clones de mandioca do programa de melhoramento de mandioca do Cerrado avaliados com respectivos códigos, genealogia e identificação da testemunha com respectivo código do Banco de Germoplasma de mandioca do Cerrado (BGMC). UnB/ Embrapa Cerrados, Brasília, DF, 2015.

\begin{tabular}{ccc}
\hline Ordem & Clones & Origem dos clones \\
\hline 1 & $341 / 08$ & BGMC 1228 polinização aberta \\
2 & $345 / 08$ & BGMC 1228 polinização aberta \\
3 & $378 / 08$ & BGMC 1228 polinização aberta \\
4 & $387 / 08$ & BGMC 1228 polinização aberta \\
5 & $390 / 08$ & BGMC 1228 polinização aberta \\
6 & $395 / 08$ & BGMC 1228 polinização aberta \\
7 & $406 / 08$ & BGMC 1415 polinização aberta \\
8 & $413 / 08$ & BGMC 1415 polinização aberta \\
9 & IAC 576-70 (BGMC 753) & - \\
\hline
\end{tabular}

O delineamento experimental utilizado foi de blocos casualizados com três repetições, sendo que cada parcela foi composta por 4 linhas de 10 plantas, com espaçamento de $0,80 \mathrm{~m}$ entre plantas e 1,20 m entre linhas. No processo de caracterização foram utilizadas as 16 plantas centrais de cada parcela, sendo que as avaliações foram feitas em 2010/2011 e repetidas em 2011/2012. A seleção do material de propagação e os tratos culturais seguiram as recomendações do sistema de produção de mandioca para a região do Cerrado (FIALHO et al., 2013, FIALHO \& VIEIRA, 2011).

Os descritores morfológicos foram avaliados no local dos experimentos nos dois anos, seguindo as instruções para a execução dos ensaios de distinguibilidade, homogeneidade e estabilidade de cultivares de mandioca (Manihot esculenta Crantz) do Ministério da Agricultura, Pecuária e Abastecimento (BRASIL, 2014) e de FUKUDA \& GUEVARA (1998). Os 40 descritores qualitativos avaliados foram: 1) coloração da folha apical; 2) pubescência do broto apical; 3) forma do lóbulo central da folha; 4) coloração do pecíolo; 5) coloração do córtex do caule; 6) coloração da epiderme externa do caule; 7) comprimento da filotaxia; 8) coloração da película da raiz; 9) coloração do córtex da raiz; 10) coloração da polpa da raiz; 11) textura da epiderme da raiz; 12) presença de floração; 13) coloração da folha desenvolvida; 14) número predominante de lóbulos nas folhas; 15) coloração da epiderme interna do caule; 16) hábito de crescimento do caule; 17) coloração dos ramos terminais nas plantas adultas; 18) constrições da raiz; 19) coloração da nervura central da folha; 20) posição do pecíolo; 
21) proeminência das gemas foliares; 22) comprimento das estípulas; 23) margem das estípulas; 24) hábito de ramificação; 25) sinuosidade do lóbulo foliar; 26) forma da raiz; 27) tipo de planta; 28) comprimento médio da raiz; 29) diâmetro médio da raiz; 30) destaque da película da raiz; 31) destaque do córtex da raiz; 32) coloração das sépalas; 33) coloração do disco da flor; 34) coloração do estigma; 35) coloração do ovário; 36) coloração das anteras; 37) presença de estames nas flores femininas; 38) presença de pólen; 39) formação de frutos e 40) rugosidade do exocarpo do fruto. As avaliações relativas a folhas e pecíolos, caule e raízes foram efetuadas respectivamente aos seis, oito e doze meses após o plantio. Já as avaliações relacionadas às flores foram realizadas quando $50 \%$ das plantas haviam florescido. Os descritores morfológicos foram fotodocumentados e foram aferidos por dois anos.

Com base na distribuição de frequência dos clones nas diferentes classes fenotípicas, foi estimada a entropia para cada descritor por meio do coeficiente de entropia de Renyi, utilizando a fórmula:

$$
\mathrm{H}=-\sum_{i=1}^{s} p_{i} \ln p_{i}
$$

Em que:

$\mathrm{H}=$ entropia de $\mathrm{n}$ genótipos em s classes fenotípicas do descritor considerado; $p_{i}=$ fi/n sendo: $\mathrm{p} 1=\mathrm{f} 1 / \mathrm{n} \mathrm{e}(\mathrm{p} 1+\mathrm{p} 2+\ldots+\mathrm{ps}=1)$ desde que $(\mathrm{n}=\mathrm{f} 1+\mathrm{f} 2+\ldots+$ fs), onde f1, f2, .. fn, correspondem ao número de genótipos em cada uma das classes fenotípicas (s) do descritor considerado.

O cálculo da estimativa da entropia foi realizado com o auxílio do programa Multiv v.2.3 (PILLAR, 1997). A entropia de um determinado descritor será tão maior quanto maior for o número de classes fenotípicas desse e quanto mais equilibrada for à distribuição de frequência dos acessos nas diferentes classes fenotípicas. Ou seja, para um descritor morfológico com duas classes fenotípicas, a maior entropia ocorrerá quando ambas as classes apresentarem 50\% dos genótipos avaliados.

A matriz de dissimilaridade genética entre os 9 genótipos, com base nos 20 marcadores morfológicos que evidenciaram polimorfismo, foi estimada por meio do complemento do índice de coincidência simples com auxílio do programa computacional Genes (CRUZ, 2001). Com base na matriz de dissimilaridade foi 
realizada a análise de agrupamento dos genótipos via dendrograma, utilizando como critério o método da ligação média entre grupos não ponderado, conhecido como UPGMA (Unweighted Pair-Group Method using Arithmetic Avarages), que utiliza as médias aritméticas (não ponderadas) das medidas de dissimilaridade. $\mathrm{O}$ ajuste entre a matriz de dissimilaridade e o dendrograma foi estimado pelo coeficiente de correlação cofenética (r), conforme SOKAL \& ROHLF (1962), com o auxílio do programa computacional NTSYS pc 2.1 (ROHLF, 2000).

\subsection{RESULTADOS E DISCUSSÃO}

Com base nos resultados obtidos, verifica-se que os clones elite de mandioca de mesa rosada avaliados, exibem variabilidade genética, uma vez que entre os 40 caracteres avaliados, metade $(50 \%)$ foram polimórficos, apresentando mais de uma classe fenotípica, sendo importantes na diferenciação dos clones (Tabelas 2 e 3). Trabalhos utilizando descritores de mandioca foram realizados anteriores demonstrando a importância das características na diferenciação dos clones (NICK et al., 2008; ALBUQUERQUE et al., 2009; MEZETTE et al., 2009; VIEIRA et al., 2013). Os resultados obtidos evidenciaram que os descritores morfológicos de mandioca selecionados para o estudo foram eficientes na determinação de diferenças morfológicas entre os genótipos avaliados, uma vez que nenhum par de genótipos apresentou 100\% de similaridade (Figura 1). Estes resultados evidenciam a utilidade destes descritores para fins de ensaios visando à caracterização de genótipos e à proteção de cultivares de mandioca. Todos os descritores obtidos em 2010/2011 foram validados em 2011/2012 evidenciando que o fator ano/safra, não influenciou a expressão fenotípica dos caracteres aferidos.

Os clones não tiveram variação para os 20 caracteres, uma vez que todos tinham o mesmo fenótipo, ou seja, cor do córtex da raiz branca ou creme, textura da epiderme da raiz rugosa, presença de floração, coloração da folha desenvolvida verde escura, coloração da epiderme do caule marrom claro, hábito de crescimento do caule reto, poucas ou nenhuma constrições na raiz, coloração da nervura central da folha verde, pecíolo na posição horizontal, proeminência de cicatrizes foliares, comprimento das estípulas longas, sinuosidade do lóbulo foliar sinuoso, coloração das sépalas verde, coloração do estigma branco ou creme, coloração do ovário verde, coloração das anteras amarelas, ausência de flores femininas sem estames, presença de pólen, presença de 
frutos e exocarpo do fruto rugoso. Dentre os caracteres que tiveram variação, aqueles com o maior número de classes fenotípicas distintas na aferição dos caracteres qualitativos, foram a forma do lóbulo central, cor do pecíolo, cor externa do caule, número de lóbulos, cor do disco ambos com três classes. Algumas classes 
Tabela 2. Caracterização morfológica dos clones de mandioca com base na cor da folha apical (CFA), pubescência do broto apical (PBA), forma do lóbulo central (FLC), cor do pecíolo (CP), cor do córtex do caule (CCC), cor externa do caule (CEC), comprimento da filotaxia (CF), cor externa da raiz (CER), cor da polpa da raiz (CPR), número de lóbulos (NL). UnB/ Embrapa Cerrados, Brasília, DF, 2015.

\begin{tabular}{|c|c|c|c|c|c|c|c|c|c|c|}
\hline \multirow[b]{2}{*}{ Clone } & \multicolumn{10}{|c|}{ Descritores morfológicos } \\
\hline & CFA & PBA & FLC & $\mathbf{C P}$ & $\mathrm{CCC}$ & CEC & $\mathbf{C F}$ & CER & CPR & NL \\
\hline IAC 576-70 & $\begin{array}{c}\text { verde } \\
\text { arroxeado }\end{array}$ & ausente & $\begin{array}{c}\text { oblongo- } \\
\text { lanceolada }\end{array}$ & $\begin{array}{c}\text { verde } \\
\text { avermelhado }\end{array}$ & $\begin{array}{l}\text { verde } \\
\text { escuro }\end{array}$ & prateado & médio & $\begin{array}{c}\text { marrom } \\
\text { escuro }\end{array}$ & creme & $\begin{array}{c}\text { sete } \\
\text { lóbulos }\end{array}$ \\
\hline $341 / 08$ & $\begin{array}{c}\text { verde } \\
\text { arroxeado }\end{array}$ & presente & lanceolada & vermelho & $\begin{array}{l}\text { verde } \\
\text { claro }\end{array}$ & $\begin{array}{l}\text { marrom } \\
\text { escuro }\end{array}$ & curto & $\begin{array}{c}\text { marrom } \\
\text { claro }\end{array}$ & rosada & $\begin{array}{l}\text { cinco } \\
\text { lóbulos }\end{array}$ \\
\hline $345 / 08$ & $\begin{array}{c}\text { verde } \\
\text { arroxeado }\end{array}$ & presente & $\begin{array}{l}\text { elíptica- } \\
\text { lanceolada }\end{array}$ & $\begin{array}{c}\text { verde } \\
\text { avermelhado }\end{array}$ & $\begin{array}{l}\text { verde } \\
\text { claro }\end{array}$ & $\begin{array}{c}\text { marrom } \\
\text { escuro }\end{array}$ & médio & $\begin{array}{c}\text { marrom } \\
\text { claro }\end{array}$ & rosada & $\begin{array}{c}\text { sete } \\
\text { lóbulos }\end{array}$ \\
\hline $378 / 08$ & $\begin{array}{l}\text { verde } \\
\text { claro }\end{array}$ & presente & lanceolada & vermelho & $\begin{array}{l}\text { verde } \\
\text { claro }\end{array}$ & $\begin{array}{c}\text { marrom } \\
\text { claro }\end{array}$ & médio & $\begin{array}{l}\text { marrom } \\
\text { escuro }\end{array}$ & rosada & $\begin{array}{c}\text { sete } \\
\text { lóbulos }\end{array}$ \\
\hline $387 / 08$ & $\begin{array}{l}\text { verde } \\
\text { claro }\end{array}$ & presente & lanceolada & $\begin{array}{c}\text { verde } \\
\text { avermelhado }\end{array}$ & $\begin{array}{l}\text { verde } \\
\text { claro }\end{array}$ & $\begin{array}{c}\text { marrom } \\
\text { claro }\end{array}$ & curto & $\begin{array}{c}\text { marrom } \\
\text { claro }\end{array}$ & rosada & $\begin{array}{c}\text { sete } \\
\text { lóbulos }\end{array}$ \\
\hline $390 / 08$ & $\begin{array}{c}\text { verde } \\
\text { arroxeado }\end{array}$ & presente & lanceolada & vermelho & $\begin{array}{l}\text { verde } \\
\text { claro }\end{array}$ & $\begin{array}{c}\text { marrom } \\
\text { claro }\end{array}$ & médio & $\begin{array}{c}\text { marrom } \\
\text { claro }\end{array}$ & rosada & $\begin{array}{c}\text { nove } \\
\text { lóbulos }\end{array}$ \\
\hline $395 / 08$ & $\begin{array}{l}\text { verde } \\
\text { claro }\end{array}$ & presente & $\begin{array}{c}\text { elíptica- } \\
\text { lanceolada }\end{array}$ & vermelho & $\begin{array}{l}\text { verde } \\
\text { claro }\end{array}$ & $\begin{array}{c}\text { marrom } \\
\text { claro }\end{array}$ & curto & $\begin{array}{c}\text { marrom } \\
\text { claro }\end{array}$ & rosada & $\begin{array}{c}\text { nove } \\
\text { lóbulos }\end{array}$ \\
\hline $413 / 08$ & $\begin{array}{c}\text { verde } \\
\text { arroxeado }\end{array}$ & presente & $\begin{array}{l}\text { elíptica- } \\
\text { lanceolada }\end{array}$ & vermelho & $\begin{array}{l}\text { verde } \\
\text { claro }\end{array}$ & $\begin{array}{c}\text { marrom } \\
\text { claro }\end{array}$ & médio & $\begin{array}{l}\text { marrom } \\
\text { claro }\end{array}$ & rosada & $\begin{array}{c}\text { sete } \\
\text { lóbulos }\end{array}$ \\
\hline
\end{tabular}


Tabela 3. Caracterização morfológica dos clones de mandioca com base na cor dos ramos terminais nas plantas adultas (CRT), margem das estípulas (ME), hábito de ramificação (HR), forma da raiz (FR), tipo de planta (TP), comprimento médio da raiz (CMR), diâmetro médio da raiz (DMR), destaque da película da raiz (DPR), diâmetro circular das raízes (DCR) e cor do disco (CD). UnB/ Embrapa Cerrados, Brasília, DF, 2015.

\begin{tabular}{|c|c|c|c|c|c|c|c|c|c|c|}
\hline \multirow[b]{2}{*}{ Clone } & \multirow[b]{2}{*}{ CRT } & \multicolumn{9}{|c|}{ Descritores morfológicos } \\
\hline & & ME & HR & FR & $\mathbf{T P}$ & CMR & DMR & DPR & DCR & CD \\
\hline IAC 576-70 & verde & laciniada & dicotômica & cilíndrica & Compacta & intermediária & intermediária & fácil & fácil & laranja \\
\hline $341 / 08$ & $\begin{array}{l}\text { verde- } \\
\text { arroxeado }\end{array}$ & laciniada & dicotômica & $\begin{array}{l}\text { cônica- } \\
\text { cilíndrica }\end{array}$ & Aberta & longa & intermediária & fácil & fácil & roxo \\
\hline $345 / 08$ & $\begin{array}{c}\text { verde- } \\
\text { arroxeado }\end{array}$ & laciniada & tricotômica & $\begin{array}{l}\text { cônica- } \\
\text { cilíndrica }\end{array}$ & Aberta & longa & intermediária & fácil & fácil & vermelha \\
\hline $378 / 08$ & $\begin{array}{l}\text { verde- } \\
\text { arroxeado }\end{array}$ & laciniada & dicotômica & $\begin{array}{l}\text { cônica- } \\
\text { cilíndrica }\end{array}$ & Aberta & ntermediária & intermediária & difícil & difícil & laranja \\
\hline $387 / 08$ & verde & laciniada & tricotômica & $\begin{array}{l}\text { cônica- } \\
\text { cilíndrica }\end{array}$ & Aberta & atermediária & intermediária & fácil & fácil & laranja \\
\hline $390 / 08$ & $\begin{array}{l}\text { verde- } \\
\text { arroxeado }\end{array}$ & inteira & tricotômica & cilíndrica & Aberta & longa & intermediária & fácil & fácil & roxo \\
\hline $395 / 08$ & $\begin{array}{l}\text { verde- } \\
\text { arroxeado }\end{array}$ & laciniada & dicotômica & $\begin{array}{l}\text { cônica- } \\
\text { cilíndrica }\end{array}$ & Aberta & intermediária & finas & difícil & fácil & laranja \\
\hline $406 / 08$ & $\begin{array}{l}\text { verde- } \\
\text { arroxeado }\end{array}$ & laciniada & tricotômica & $\begin{array}{l}\text { cônica- } \\
\text { cilíndrica }\end{array}$ & Aberta & longa & finas & fácil & fácil & vermelha \\
\hline $413 / 08$ & $\begin{array}{l}\text { verde- } \\
\text { arroxeado }\end{array}$ & laciniada & dicotômica & $\begin{array}{l}\text { cônica- } \\
\text { cilíndrica }\end{array}$ & Aberta & longa & finas & fácil & fácil & roxo \\
\hline
\end{tabular}


fenotípicas apresentaram variações somente para a testemunha IAC 576-70 sendo a variedade recomendada para cultivo na região do Cerrado, que diferiu dos demais genótipos por apresentar ausência de pubescência no broto apical, cor do córtex do caule verde escuro, e cor da polpa da raiz creme, cor dos ramos terminais nas plantas adultas verde e tipo de planta compacta. A maioria dos caracteres apresentou duas classes fenotípicas (Tabelas 2 e 3).

Com base na análise visual da Figura 1, foi possível verificar a formação de três grupos de similaridade: i) 341/08, 413/08, 390/08, 345/08, 406/08; ii) 378/08, 395/08, 387/08, e iii) IAC 576-70, sendo observada uma clara tendência de agrupamento dos clones em função de sua genealogia. O elevado coeficiente de correlação cofenética do dendrograma $(r=0,92)$ revelou o elevado ajuste entre a representação gráfica da similaridade genética e a matriz de similaridade, o que justifica que sejam realizadas inferências por meio da avaliação visual da Figura 1. Em trabalho realizado por VIEIRA et al. (2011) foi observada uma clara subdivisão dos genótipos em diferentes grupos de similaridade evidenciando uma tendência de agrupamento dos acessos com base na cor da polpa da raiz de reserva. Já no trabalho de DUPUTIÉ et al. (2009), não foi observada esta clara subdivisão dos genótipos em diferentes grupos de similaridade, não encontrando uma clara estruturação da diversidade genética, o que pode ser explicado pelo fato de haver uma constante troca de genótipos entre os produtores de diferentes regiões, gerando fluxo gênico e dificuldades na identificação da origem exata dos acessos.

Com base na matriz de dissimilaridade genética entre os clones, verificou-se que os clones geneticamente mais próximos foram o 413/08 do 341/08, 406/08 do 345/08, 413/08 do 345/08 e 413/08 do 406/08 com uma dissimilaridade de 0,25 (Figura 1). Estes, porem, possuem a mesma genealogia. A maior distância genética foi observada entre os clones 395/08 com coloração da polpa da raiz rosada e IAC 576-70 variedade recomendada para o plantio na região do Cerrado brasileiro, com uma dissimilaridade de 0,75 . 


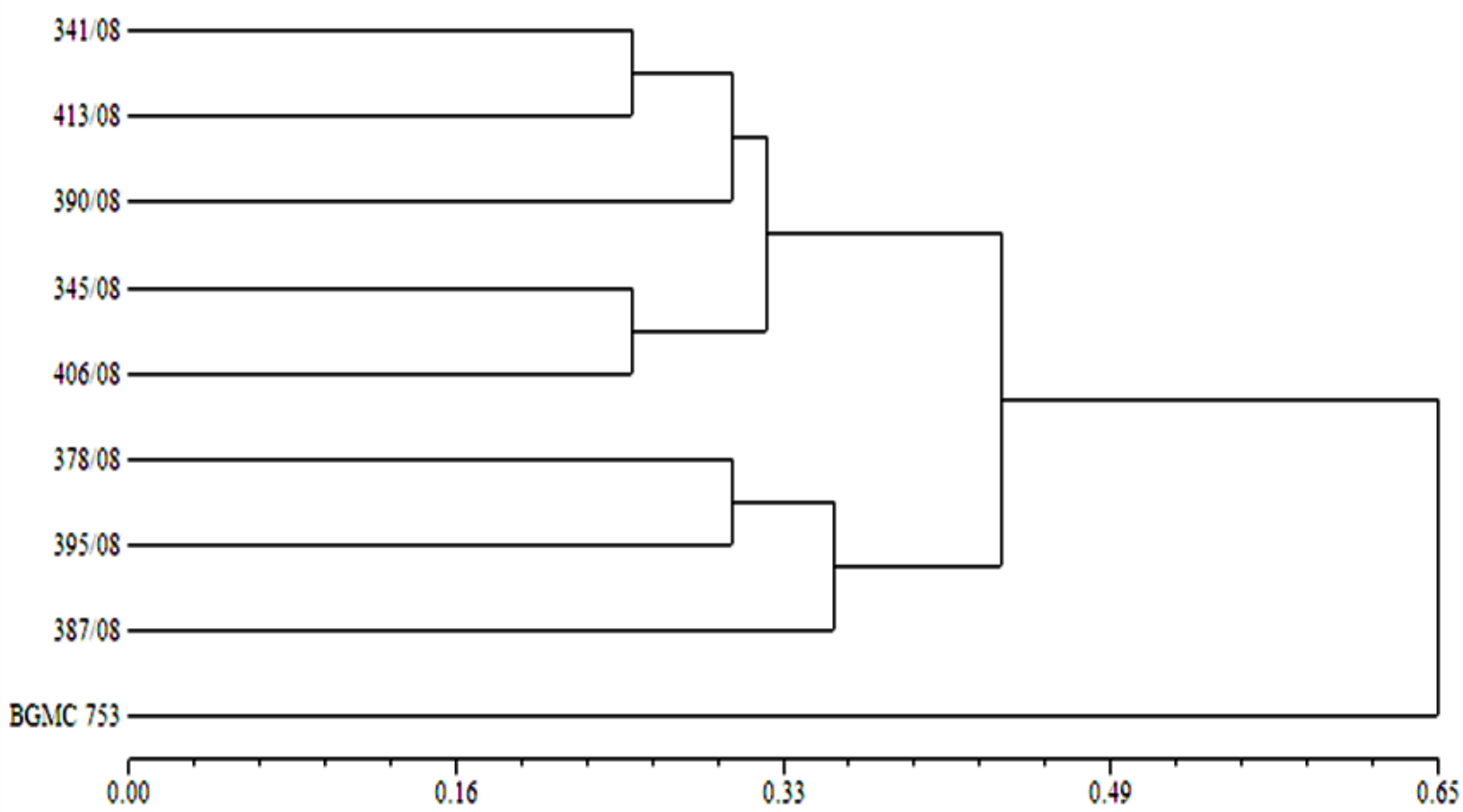

Figura 1. Análise de agrupamento de 9 clones de mandioca, obtido pelo método de agrupamento UPGMA, com base na matriz de dissimilaridade genética obtida por meio do complemento do índice de similaridade de coincidência simples, utilizando 20 descritores morfológicos qualitativos. $\mathrm{O}$ valor do coeficiente de correlação cofenética (r) é de 0,92 .

A maior dissimilaridade genética entre os clones 395/08 e o IAC 576-70 é confirmada pelas diferenças desses dois genótipos em vários descritores: cor da folha apical, pubescência do broto apical, forma do lóbulo central, cor do pecíolo, cor do córtex do caule, cor externa do caule, comprimento da filotaxia, cor externa da raiz, cor da polpa da raiz, número de lóbulos, cor dos ramos terminais nas plantas adultas, forma da raiz, tipo de planta, diâmetro médio da raiz e destaque da película da raiz. Na Figura 2 destacamos alguns desses caracteres que diferenciam os clones 395/08 e IAC 576-70. A presença de variabilidade entre os dois genótipos era esperada, uma vez que um é um clone em processo de melhoramento genético com coloração da polpa das raízes rosada e outra a variedade de mandioca recomendada para o cultivo na região que possui a coloração da polpa creme. 


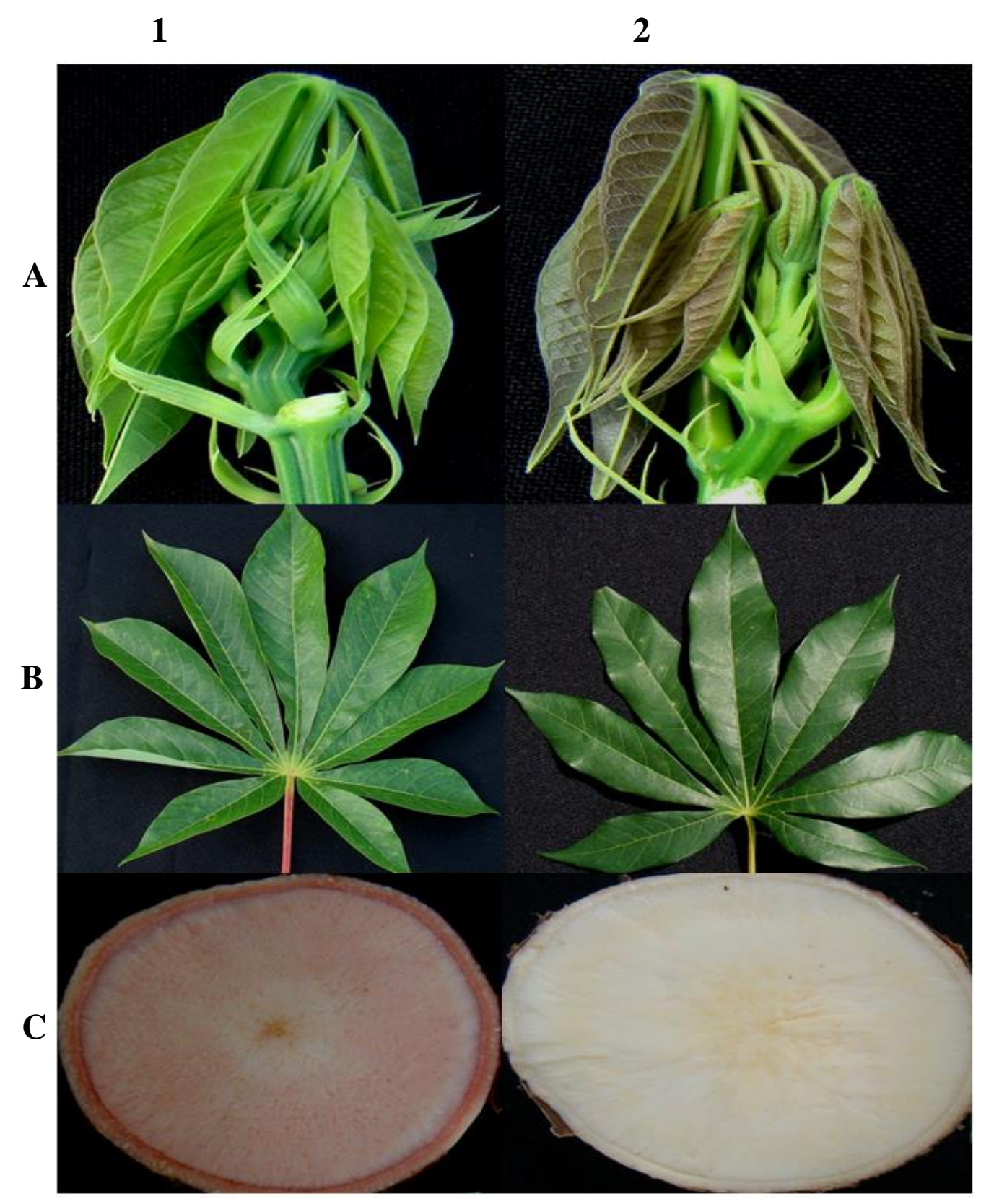

Figura 2. Comparação de dissimilaridade entre o clone 395/08 (1) e a testemunha IAC 576-70 (2) com relação à coloração das folhas apicais (A), forma do lóbulo central, numero de lóbulos (B) e coloração da polpa da raiz (C).

Dentre os caracteres aferidos, alguns se destacaram em função de expressarem elevada entropia: cor do disco $(1,06)$; forma do lóbulo central $(0,94)$ e cor do pecíolo $(0,94)$ (Tabela 4), sendo que estes caracteres apresentam em comum o fato de serem pouco relacionados com caracteres agronômicos de interesse o que provavelmente fez com que estes fossem pouco visados durante o processo de seleção realizado tanto pelos melhoristas como no inicio da domesticação da espécie (VIEIRA et al., 2008). 
Dentre os caracteres avaliados, alguns são de grande importância para o melhoramento genético de mandioca de mesa biofortificada, como a coloração da polpa da raiz que é de grande importância comercial para a mandioca de mesa na região do Cerrado. Esta característica está diretamente relacionada com a presença de carotenóides como $\beta$-caroteno nas raízes de coloração amarela e o licopeno nas raízes de coloração rosada (CARVALHO et al., 2011; CARVALHO et al., 2012; SILVA et al., 2014). Esses carotenóides têm importância na alimentação humana pelos benefícios do $\beta$-caroteno como precursor da vitamina A, que é importante para o crescimento, desenvolvimento, manutenção de tecidos epiteliais, sistema imunológico e, em especial para o funcionamento do ciclo visual na regeneração de fotorreceptores (AMBROSIO et al., 2006). O licopeno protege moléculas de lipídios, lipoproteínas de baixa densidade, proteínas e DNA contra ataque dos radicais livres, tendo um papel essencial na proteção contra doenças (SHAMI \& MOREIRA, 2004). Dentre os genótipos avaliados, 89\% dos clones têm cor da polpa das raízes rosada e $11 \%$ têm cor creme, característica da variedade IAC 576-70 usada como testemunha.

Quanto ao destaque do córtex da raiz, os programas de melhoramento genético de mandioca de mesa objetivam cultivares com fácil destaque. Verificou-se que $89 \%$ dos clones expressaram esse fenótipo desejável. Outro caractere de importância é o comprimento médio das raízes, uma vez que os consumidores de mandioca têm preferência por cultivares com raízes de tamanho médio. Entre os clones avaliados, $44 \%$ expressaram esse fenótipo desejável. Outros caracteres também apresentaram fenótipos desejáveis como: i) diâmetro médio da raiz, o ideal é o fenótipo com diâmetro intermediário, o qual está intimamente relacionado à qualidade e ao padrão da raiz de mandioca, sendo observado em $67 \%$ dos genótipos avaliados, ii) coloração da película da raiz, sendo que o ideal para a produção de mandioca de mesa são as mandiocas com coloração externa da raiz marrom claro e marrom escuro, o que foi observado em $100 \%$ dos genótipos (Tabela 4). Essas características fenotípicas são importantes no momento da seleção de genótipos, nos tratos culturais e na colheita facilitando seu manejo, sendo preferidas pelos produtores e algumas características de importância para a comercialização do produto no mercado, objetivando sua utilização de forma direta pelos produtores ou indireta, no desenvolvimento de variedades adaptadas a locais específicos (NICK et al., 2008, SILVA et al., 2014). 
Tabela 4. Caracteres avaliados, classes fenotípicas, frequência de clones e estimativa do coeficiente de entropia em cada uma das classes. UnB/ Embrapa Cerrados, Brasília, DF, 2015.

\begin{tabular}{|c|c|c|c|}
\hline Caracteres & Classes fenotípicas & $\begin{array}{c}\text { Frequência dos } \\
\text { genótipos }(\%)\end{array}$ & Entropia $(\mathbf{H})$ \\
\hline Cor da folha apical & $\begin{array}{c}\text { verde claro } \\
\text { verde arroxeado }\end{array}$ & $\begin{array}{l}33 \\
67\end{array}$ & 0.64 \\
\hline Pubescência do broto apical & $\begin{array}{l}\text { ausente } \\
\text { presente }\end{array}$ & $\begin{array}{l}11 \\
89\end{array}$ & 0.35 \\
\hline Forma do lóbulo central & $\begin{array}{c}\text { elíptica-lanceolada } \\
\text { oblonga-lanceolada } \\
\text { lanceolada }\end{array}$ & $\begin{array}{l}33 \\
11 \\
56\end{array}$ & 0.94 \\
\hline Cor do pecíolo & $\begin{array}{c}\text { verde avermelhado } \\
\text { vermelho esverdeado } \\
\text { vermelho }\end{array}$ & $\begin{array}{l}33 \\
11 \\
56\end{array}$ & 0.94 \\
\hline Cor do córtex do caule & $\begin{array}{l}\text { verde claro } \\
\text { verde escuro }\end{array}$ & $\begin{array}{l}89 \\
11\end{array}$ & 0.35 \\
\hline Cor externa do caule & $\begin{array}{l}\text { marrom claro } \\
\text { prateado } \\
\text { marrom escuro }\end{array}$ & $\begin{array}{l}67 \\
11 \\
22\end{array}$ & 0.85 \\
\hline Comprimento da filotaxia & $\begin{array}{l}\text { curto }(<8 \mathrm{~cm}) \\
\text { médio }(8-15 \mathrm{~cm})\end{array}$ & $\begin{array}{l}33 \\
67\end{array}$ & 0.64 \\
\hline Cor externa da raiz & $\begin{array}{l}\text { marrom claro } \\
\text { marrom escuro }\end{array}$ & $\begin{array}{l}67 \\
33\end{array}$ & 0.64 \\
\hline Cor da polpa da raiz & $\begin{array}{l}\text { creme } \\
\text { rosada }\end{array}$ & $\begin{array}{l}11 \\
89\end{array}$ & 0.35 \\
\hline Número de lóbulos & $\begin{array}{l}\text { cinco } \\
\text { sete } \\
\text { nove }\end{array}$ & $\begin{array}{l}11 \\
67 \\
22\end{array}$ & 0.85 \\
\hline Cor dos ramos terminais & $\begin{array}{c}\text { verde } \\
\text { verde-arroxeado }\end{array}$ & $\begin{array}{l}22 \\
78\end{array}$ & 0.53 \\
\hline Margem estípulas & $\begin{array}{c}\text { laciniada } \\
\text { inteira }\end{array}$ & $\begin{array}{l}89 \\
11\end{array}$ & 0.35 \\
\hline Hábito de ramificação & $\begin{array}{l}\text { dicotômica } \\
\text { tricotômica }\end{array}$ & $\begin{array}{l}56 \\
44\end{array}$ & 0.69 \\
\hline Forma da raiz & $\begin{array}{l}\text { cônica-cilíndrica } \\
\text { cilíndrica }\end{array}$ & $\begin{array}{l}78 \\
22\end{array}$ & 0.53 \\
\hline Tipo de planta & $\begin{array}{c}\text { compacta } \\
\text { aberta }\end{array}$ & $\begin{array}{l}11 \\
89\end{array}$ & 0.35 \\
\hline Comprimento médio da raiz & $\begin{array}{c}\text { intermediária } \\
\text { longa }\end{array}$ & $\begin{array}{l}44 \\
56\end{array}$ & 0.69 \\
\hline Diâmetro médio da raiz & $\begin{array}{c}\text { finas } \\
\text { intermediária }\end{array}$ & $\begin{array}{l}33 \\
67\end{array}$ & 0.64 \\
\hline Destaque da película da raiz & $\begin{array}{c}\text { fácil } \\
\text { difícil }\end{array}$ & $\begin{array}{l}78 \\
22\end{array}$ & 0.53 \\
\hline Destaque do córtex da raiz & $\begin{array}{c}\text { fácil } \\
\text { difícil }\end{array}$ & $\begin{array}{l}89 \\
11\end{array}$ & 0.35 \\
\hline Cor do disco & $\begin{array}{l}\text { laranja } \\
\text { vermelho } \\
\text { roxo }\end{array}$ & $\begin{array}{l}44 \\
22 \\
33\end{array}$ & 1.06 \\
\hline
\end{tabular}


Com base nos resultados obtidos no trabalho, é possível sugerir que no grupo de clones de mandioca rosada avaliados, há clones com potencial para recomendação para cultivo comercial na região do Cerrado e outros que podem ser usados no desenvolvimento de variedades adaptadas a locais específicos, uma vez que vários deles têm caracteres desejáveis do ponto de vista agronômico e morfológico. Trabalhos complementares de desempenho agronômico e também de análise das qualidades nutricionais estão sendo realizados em várias regiões do Cerrado, tendo como objetivo finalístico o desenvolvimento e disponibilização de cultivares melhoradas para a região.

\subsection{CONCLUSÕES}

Os clones avaliados tiveram variabilidade fenotípica para os caracteres que foram aferidos, demonstrando a possibilidade da diferenciação dos mesmos para fins de ensaios de caracterização de genótipos visando à proteção de cultivares de mandioca e seleção de genitores para uso em programas de melhoramento genético.

No grupo de clones avaliados, há genótipos com potencial para recomendação para cultivo comercial, uma vez que vários deles têm caracteres morfológicos desejáveis do ponto de vista agronômico e comercial. 


\subsection{REFERÊNCIAS BIBLIOGRÁFICAS}

AGUIAR, J.L.P.; BARRETO, B.; SOUSA, T.C.; FIALHO, J.F. Cadeia produtiva da mandioca no Distrito Federal: Caracterização do consumidor final. In: CONGRESSO BRASILEIRO DE MANDIOCA, XI, 2005, Campo Grande. Resumos... Campo Grande, MS: Embrapa Agropecuária Oeste, 2005.

AlBUQUERQUE, J. A. A. SEDIYAMA, T.; SILVA, A. A. da; SEDIYAMA, C. S.; ALVES, J. M. A.; NETO, F. de A. Caracterização morfológica e agronômica de clones de mandioca cultivados no Estado de Roraima. Revista Brasileira de Ciências Agrárias, v. 04, n. 04, p. 388-394, 2009.

AMBROSIO, C. L. B.; CAMPOS, F. de A. C, e S.; Carotenóides como alternativa contra a hipovitaminose A. Revista de Nutrição,Campinas, v.19, p. 233-243, 2006.

BRASIL. Ministério da Agricultura, Pecuária e Abastecimento. Proteção de cultivares. Brasília, DF, 2010. Disponível em: <http://www.agricultura.gov.br/vegetal/registrosautorizacoes/protecao-cultivares/formularios-protecao-cultivares>. Acesso em: 16 fev. de 2010.

CARVALHO, L.J.C.B.; VIEIRA, E.A.; FIALHO, J. de F.; SOUZA, C.R.B. A genomic assisted breeding program for cassava to improve nutritional quality and industrial traits of storage root. Crop Breeding and Applied Biotechnology, v.11, p.289-296, 2011. Acesso em: 22 abr. 2013. doi: 10.1590/S1984-70332011000400001.

CARVALHO, L. J. C. B.; LIPOLIS, J. ; CHEN, S.; SOUZA, C. R. B.; VIEIRA, E.A.; JAMES, V. A. Characterization of carotenoid-protein complexes and gene expression analysis associated with carotenoid sequestration in pigmented cassava (Manihot Esculenta Crantz) storage root. The Open Biochemistry Journal, v. 6, p. 116-130, 2012. doi: 10.2174/1874091X01206010116.

CRUZ, C.D. Programa genes: aplicativo computacional em genética e estatística. Viçosa: UFV, 2001. 648p.

DUPUTIÉ, A. et al. Traditional Ameridian cultivators combine directional and ideotypic selection for sustainable management of cassava genetic diversity. Journal of Evolutionary Biology, v. 22, n.06, p. 1317-1325, 2009.

FAO. Maiores produtores mundiais de mandioca.<http:// apps.fao.org/egibin/nphdb.pl2005.> Acesso em 15 jan. 2013.

FIALHO, J. F.; SOUSA, D. M. G.; VIEIRA, E. A. Manejo do solo no cultivo de 
mandioca. In: FIALHO, J.F.; VIEIRA, E. A. (Eds.). Mandioca no Cerrado: orientações técnicas. 2. ed. Planaltina: Embrapa Cerrados, 2013. p. 39-60.

FIALHO, J. F.; VIEIRA, E. A.; SILVA, M. S.; PAULA-MORAES, S. V.; FUKUDA, W. M. G.; SANTOS FILHO, M. O. S; SILVA, K. N. Desempenho de variedades de mandioca de mesa no Distrito Federal. Revista Brasileira de Agrociência, v.15, n. 1-4, p.31-35, 2009.

FUKUDA, W. M. G. Melhoramento da mandioca. In. BORÉM, A. (Ed.). Melhoramento de espécies cultivadas. Viçosa: UFV, 1999. p.409-428.

FUKUDA, W. M. G.; GUEVARA, C. L. Descritores morfológicos e agronômicos para a caracterização de mandioca (Manihot esculenta Crantz). Cruz das Almas: CNPMF, 1998, 38p.

IBGE. Disponível <http://www.ibge.gov.br>. Acesso em 15 jan. 2013.

MEZETTE, T. F. et al. Seleção de clones-elite de mandioca de mesa visando a características agronômicas, tecnológicas e químicas. Bragantia, v. 68, n. 03, p. 601$609,2009$.

NICK, C.; CARVALHO, M.; ASSIS, L. H. B. de; CARVALHO, S. P. de. Genetic dissimilarity in cassava clones determined by multivariate techniques. Crop Breeding and Applied Genetics, v. 08, n. 02, p. 104-110, 2008.

PILLAR, V.P. Multivariate exploratory analysis and randomization testing using Multiv. Coenoses, v.12, n.1, p.145-148, 1997.

ROHLF, F. J. NTSYS-pc: numerical taxonomy and multivariate analysis system, version 2.1. New York: Exeter Software, 2000. 98p.

SHAMI, N.J.I.E.; MOREIRA, E.A.M. Licopeno como agente antioxidante. Revista de Nutrição, v.17, p. 227-236, 2004.

SILVA, K. N.; VIEIRA, E. A.; FIALHO, J. de F.; CARVALHO, L. J. C. B.; SILVA, M. S. Potencial agronômico e teor de carotenoides em raízes de reserva de mandioca. Ciência Rural (UFSM. Impresso), v. 44, p. 1348-1354, 2014.

SOKAL, R.R.; ROHLF, F.J. The comparison of dendrograms by objective methods. Taxon, v.11, p.30-40, 1962.

SOUZA, L.S.; FIALHO, J.F. Sistema de produção de mandioca para a região do cerrado. Cruz da Almas: CNPMF, 2003. 61f.

VIEIRA, E.A,; FIALHO, J. F.; FALEIRO, F.G.; BELLON, G.; FONSECA, K.G.; CARVALHO, L. J. C. B.; SILVA, M. S.; MORAES, S. V. P.; SANTOS FILHO, M. O. S. and SILVA, K. N. Divergência genética entre acessos açucarados e não açucarados 
de mandioca. Pesquisa Agropecuária Brasileira, v.43, p. 1707-1715, 2008.

VIEIRA, E.A.; FIALHO, J.F.; FALEIRO, F.G.; BELLON, G.; FONSECA, K.G.;

SILVA, M.S.; PAULA-MORAES, S.V.; CARVALHO. L.J.C.B. Caracterização fenotípica e molecular de acessos de mandioca de indústria com potencial de adaptação às condições do cerrado do Brasil Central. Semina: Ciências Agrárias, v.34, p.567$582,2013$.

VIEIRA, E.A.; FIALHO, J.F.; SILVA, M.S. Recursos genéticos e melhoramento da mandioca In: FIALHO, J.F.; VIEIRA, E.A. (Eds). Mandioca no Cerrado: orientações técnicas. Brasília-DF: Embrapa Cerrados, v.1, p. 25-35, 2011. 
CAPÍTULO 4. CARACTERES AGRONÔMICOS E BIOQUÍMICOS DE CLONES ELITE DE MANDIOCA DE MESA ROSADA BIOFORTIFICADA

CHAPTER 4. AGRONOMIC AND BIOCHEMICAL CHARACTERS IN SWEET CASSAVA ELITE CLONES WITH BIOFORTIFIED PINKISH PULP 


\section{RESUMO}

Atualmente os programas de melhoramento genético de mandioca de mesa estão focados no desenvolvimento de variedades biofortificadas que aliem aos caracteres agronômicos a presença de carotenóides. O trabalho foi realizado com o objetivo, avaliar por meio de caracteres agronômicos e bioquímicos 8 clones de mandioca de mesa rosada, em comparação com a variedade testemunha IAC 576-70, avaliados em experimentos conduzidos na Embrapa Cerrados por duas safras. Os parâmetros avaliados foram altura da planta, altura da primeira ramificação, peso da parte aérea sem a cepa, produtividade de raízes, porcentagem de amido nas raízes por meio do método da balança hidrostática, tempo para a cocção e teor de ácido cianídrico nas raízes. Foi utilizado o delineamento experimental de blocos casualizados com três repetições. As médias dos caracteres foram agrupadas por meio do teste aglomerativo de SCOTT \& KNOTT a $5 \%$ de probabilidade de erro. Com base nos caracteres altura da primeira ramificação, destacam-se os clones (390/08, 345/08 e a testemunha IAC 576-70), altura da planta (clones 390/08, 345/08 e 378/08), peso da parte aérea sem a cepa (clones 390/08, 406/08, 390/08, 378/08 e 341/08), porcentagem de amido nas raízes (clones 378/08, 413/08, 390/08 e a testemunha IAC 576-70), produtividade de raízes (testemunha IAC 576-70 e clones 341/08, 406/08, 390/08 e 387/08). Com relação ao tempo de cocção referente a safra 2011/2012, todos os clones cozinharam em tempo inferior a 30 minutos. Com relação o teor de carotenóides totais nas raízes os clones que se destacaram foram 406/08 e 341/08. Em relação ao teor de proteínas nas raízes o clone 406/08 e a testemunha IAC 576-70. Se destacaram em todos os clones avaliados os teores de $\mathrm{HCN}$ nas raízes de reserva de mandioca foram inferiores a $100 \mathrm{mg} \mathrm{Kg}^{-1}$. As características analisadas sob o ponto de vista agronômico e bioquímico nos clones elite evidenciam alta potencial para cultivo direto pelos produtores na região do Cerrado do Brasil Central.

Palavras-chaves: Manihot esculenta Crantz, melhorameto genético, caracteres agronômico, caracteres bioquímico, clone, biofortificação, recursos genéticos 


\section{ABSTRACT}

Nowadays the breeding of edible cassava programs are focused on developing biofortified varieties that combine the agronomic traits with the presence of carotenoids. The objective of this work was to evaluate by means of characterize agronomic and biochemical, 8 pinkish table cassava clones were characterized, compared with the control variety IAC 576-70, evaluated in experiments conducted at Embrapa Cerrado for two crop seasons. The parameters evaluated were plant height, the first branch point, and shoot weight without strain, productivity roots, and percentage of starch in the roots by the method of hydrostatic balance, time for cooking and acid cyanide content in the roots. An experimental randomized block design with three replications was used. The mean characters were grouped by the agglomerative SCOTT \& Knott test at 5\% probability of error. With results show based on the character height of the first branch, stand out clones (390/08, 345/08 and the witness IAC 576-70), plant height (clones 390/08, 345/08 and 378/08), shoot weight without strain (clones 390/08, 406/08, 390/08, 378/08 and 341/08), percentage of starch in the roots (clones 378/08, 413/08, 390/08 and witness IAC 576-70), roots of productivity (witness IAC 576-70, clones 341/08, 406/08, 390/08 and 387/08). Regarding the cooking time in the 2011/2012 regarding, all clones cooked in time less than 30 minutes. Regarding the total carotenoid content in the roots clones that stood out were 406/08 and 341/08. In respect to the protein content in the roots clone 406/08 and the witness IAC 576-70 stood out. In all clones evaluated the levels of $\mathrm{HCN}$ in cassava storage roots were less than $100 \mathrm{mg} \mathrm{Kg}^{-1}$. The characteristics analyzed from the point of view agronomic and biochemical in elite clones show high potential for direct cultivation by farmers in Central Brazil's Cerrado region.

Key words: Manihot esculenta Crantz, genetic breeding, characterize agronomic, characterize biochemical, clone, biofortified, genetic resources 


\subsection{INTRODUÇÃO}

No Brasil, centro de origem e de diversidade da espécie (OLSEN, 2004; CARVALHO, 2005), a mandioca é cultivada em todas as regiões, ocupando papel de destaque na indústria, alimentação humana e animal (LORENZI \& DIAS, 1993). As variedades de mandioca são classificadas como mansas ou bravas, dependendo do conteúdo de ácido cianídrico (HCN) em suas raízes. Esse ácido é uma substância tóxica resultante da hidrólise de um glicosídeo cianogênico, que, quando consumida em altos níveis, é capaz de causar intoxicações.

A biofortificação de alimentos é uma maneira de suprir a deficiência de micronutrientes, sendo uma alternativa no combate a deficiências específicas de grupos com grande carência nutricional. Na maioria dos produtos, a biofortificação é feita com a utilização de carotenóides pelo fato de apresentarem toxicidade menor do que a vitamina A (ZANCUL, 2004). Carotenóides são pigmentos presentes em plantas e alimentos que têm sido alvo de vários estudos em nutrição humana na prevenção de doenças, atribuindo sua ação às suas propriedades antioxidantes. Um dos mais conhecidos carotenóides é o betacaroteno, molécula precursora da vitamina A cuja composição é exatamente a metade daquele carotenóide (RODRIGUEZ-AMAYA \& KIMURA, 2004). Algumas das principais fontes de carotenóides são cenouras e abóboras ( $\alpha$ e $\beta$-caroteno), tomates e produtos derivados, como extrato, polpa e molhos (licopeno) e espinafre (luteína). O licopeno aparece atualmente como um dos mais potentes antioxidantes, sendo sugerido na prevenção da carcinogênese e aterogênese por proteger moléculas como lipídios, lipoproteínas de baixa densidade (LDL), proteínas e DNA (SHAMI \& MOREIRA, 2004).

Atualmente o melhoramento genético de mandioca de mesa objetiva a geração de cultivares específicos para a produção de raízes tuberosas para uso culinário nas formas cozida, frita, chips, mandioca palito, pré-cozida, massas, entre outros. Os cultivares para tal fim devem se aliar a baixos teores de ácido cianídrico nas raízes (menos de $100 \mathrm{ppm}$ ), elevada produtividade de raízes com boas qualidades sensoriais (maciez e plasticidade após cozimento, massa não pegajosa, aroma e aparência agradável) e culinárias (poucas fibras, baixo tempo para a cocção e massa cozida homogênea), resistência a pragas e doenças, arquitetura favorável a tratos culturais (não ramifique ou ramifique o mais alto possível), raízes com baixa deterioração pós- 
colheita, precocidade (colheita até 12 meses), entre outras características (VIEIRA et al., 2011).

Neste trabalho, objetivou-se avaliar a características agronômicas e bioquímicas em raízes de reserva de clones elite de mandioca rosada de mesa, tendo em vista que tais caracteristicas refletem o real potencial produtivo e qualitativo dos clones visando a utilização direta pelos produtores e/ou a utilização como genitores em programas de melhoramento genético de mandioca de mesa.

\subsection{MATERIAL E MÉTODOS}

O trabalho foi conduzido no campo experimental e no Laboratório de Raízes e Tubérculos da Embrapa Cerrados (CPAC), em Planaltina-DF, entre outubro de 2010 e outubro de 2011 e entre novembro de 2011 e novembro de 2012. A Embrapa Cerrados está situada à $15^{\circ} 39^{\prime} 84^{\prime \prime}$ de latitude $\mathrm{S}$ e $47^{\circ} 44^{\prime} 41^{\prime}$ ' de longitude $\mathrm{W}$, latitude de 1.000 metros, em Latossolo Vermelho Escuro, textura argilosa, No período de condução dos experimentos (safras 2010/2011 e 2011/2012), respectivamente, as médias das temperaturas máximas diárias foram de $27,88^{\circ} \mathrm{C}$ e $28,27^{\circ} \mathrm{C}$, as médias das temperaturas mínimas diárias foram de $16,05^{\circ} \mathrm{C}$ e $16,77^{\circ} \mathrm{C}$, as médias das temperaturas médias diárias foram de $21,28^{\circ} \mathrm{C}$ e $21,77^{\circ} \mathrm{C}$, as médias de umidade relativa do ar foram de $68,96 \%$ e $66,79 \%$, as velocidades médias dos ventos foram de $2,03 \mathrm{~m} \mathrm{seg}^{-1}$ e $2,08 \mathrm{~m} \mathrm{seg}^{-1}$, as médias de horas de insolação diária foram de 7,03 h e 6,88 h, as médias de radiação diárias foram de $18,98 \mathrm{MJ} \mathrm{m}^{-2}$ e $19,14 \mathrm{MJ} \mathrm{m}^{-2}$, as precipitações acumuladas foram de $1367 \mathrm{~mm}$ e $1402 \mathrm{~mm}$ e as médias de evapotranspiração potencial foram de 4,23 mm e $4,31 \mathrm{~mm}$.

Para a realização do estudo foram caracterizados oito clones elite de mandioca rosada de mesa (clone 341/08, clone 345/08, clone 378/08, clone 387/08, clone 390/08, clone 395/08, clone 406/08, clone 413/08) selecionados para as condições do Cerrado, sendo utilizada como testemunha a variedade de mandioca de mesa IAC 576-70, que no Banco de Germoplasma de Mandioca do Cerrado (BGMC) está identificada como BGMC 753 e que é indicada para o cultivo na região (FIALHO et al., 2009).

O delineamento experimental utilizado foi de blocos casualizados com três repetições, sendo que cada parcela foi composta por 4 linhas de 10 plantas, com espaçamento de 0,80 $\mathrm{m}$ entre plantas e 1,20 $\mathrm{m}$ entre linhas. No processo de caracterização foram utilizadas as 16 plantas centrais de cada parcela, sendo que as 
avaliações foram feitas em 2010/2011 e repetidas em 2011/2012. A seleção do material de propagação e as práticas culturais seguiram as recomendações do sistema de produção de mandioca para a região do Cerrado (FIALHO et al., 2013, FIALHO \& VIEIRA, 2013).

Os descritores agronômicos foram avaliados no local dos experimentos e no Laboratório de Raízes e Tubérculos nos dois anos. Foram avaliados seis descritores quantitativos: 1) altura da planta em metro (AP); 2) altura da primeira ramificação em metro (APR); 3) peso da parte aérea sem a cepa em $\mathrm{Kg} \mathrm{ha}^{-1}$ (PPA); 4) produtividade de raízes em $\left.\mathrm{Kg} \mathrm{ha}^{-1}(\mathrm{PR}) ; 5\right)$ porcentagem de amido nas raízes por meio do método da balança hidrostática (AM), descrito por Grosmann \& Freitas (1950); 6) tempo para a cocção em minutos (TC) de acordo com o método descrito por BORGES et al. (2002).

Caracteres bioquímicos foram avaliados três no Laboratório de Raízes e Tubérculos e no Laboratório de Bioquímica nos dois períodos. Como teor de ácido cianídrico nas raízes $\left(\mathrm{mg} \mathrm{Kg}^{-1}\right)$ por meio do método qualitativo, descrito por WILLAMS \& EDWARDS (1980), a partir de cinco raízes de reserva tomadas ao acaso por parcela.

Para a determinação do teor de carotenóides nas raízes de reserva, no momento da colheita em campo, três raízes de reserva (RR) uniformes de mandioca padrão comercial de cada parcela experimental foram selecionadas, identificadas e imediatamente colocadas em caixas de isopor com gelo, as quais foram levadas ao Laboratório, sob baixa iluminação, as amostras foram lavadas e descartando-se os tecidos mais externos (periderme, cambio e floema), amostrando-se pedaços de $1 \mathrm{~cm}$ de espessura para compor a amostra de análise. As amostras foram lavadas em água deionizada e purificada em sistema Melli-q, secadas em papel toalha, identificadas, embaladas em papel alumínio e imediatamente congeladas em nitrogênio líquido. Após esse congelamento, as amostras foram armazenadas à $-80^{\circ} \mathrm{C}$. As amostras foram liofilizadas até a desidratação completa, maceradas com o uso de gral e pistilo de porcelana, mantendo-se o resfriamento com nitrogênio líquido, até a obtenção de pó uniforme, o qual foi armazenado à $-80^{\circ} \mathrm{C}$ até sua utilização.

Para a extração e a quantificação de carotenóides totais foi utilizado cerca de 100 mg de pó da raiz de reserva, o qual foi hidratado com $3 \mathrm{~mL}$ de tampão de extração (TEx) composto com Tris $50 \mathrm{mM} \mathrm{pH} \mathrm{7,6,} \mathrm{NaCl} 100 \mathrm{mM}$, EDTA $5 \mathrm{mM}$. As etapas para a extração de carotenóides utilizadas neste trabalho foram as mesmas descritas por CARVALHO et. al (2013).

Após a extração, os carotenóides totais foram quantificados por meio da leitura 
da densidade ótica do extrato no comprimento de onda variando de 300 a 550ๆm, com leitura em $470 \eta \mathrm{m}$, a partir dos dados das avaliações calculou-se o teor de carotenóides totais em $\mu \mathrm{g} \mathrm{g}^{-1}(\mathrm{CT})$, conforme modelo matemático proposto por RODRIGUEZAMAYA \& KIMURA (2004):

$$
\mathrm{CT}=\frac{\mathrm{OD} \times 10^{4} \times \mathrm{V}}{A \%^{1}{ }_{1 \mathrm{~cm}} \times \mathrm{DWt}}
$$

Em que:

CT: teor de carotenóides totais;

$\mathrm{OD}=$ densidade ótica da amostra no $\lambda \max$,

$A^{1}{ }_{1 \mathrm{~cm}}=3450$ - coeficiente de extinção do licopeno em éter de petróleo;

$\mathrm{V}=$ volume da extração $(\mathrm{mL})$;

DWt $=$ peso do pó desidratado de raiz de reserva.

Para a extração e a quantificação de proteínas totais foi utilizada a fração proteica contida no precipitado da extração dos carotenóides e descrito em CARVALHO et al., 2013 com algumas modificações. Foi solubilizada em tampão de suspensão de proteínas (TSP contendo Tris $1 \mathrm{M} \mathrm{pH} \mathrm{7,6,} \mathrm{NaCl} 5$ M, EDTA 0,5 M, Chaps 100 mM, DTT 500 mM, Pefabloc 200 mM), seguindo de vortex, sônicação por 15 min., votex, aqueceu em Banho Maria $\left(80^{\circ} \mathrm{C}\right)$ até gelatinizar o amido e solubilizar as proteínas, vortex, centrifuga $\left(5000 \mathrm{rpm} / 4^{\circ} \mathrm{C} / 15 \mathrm{~min}\right.$.) coletou-se o sobrenadante para quantificação de proteínas totais foi feita pelo método de Bradford (BioRad microassay) utilizando-se $50 \mu \mathrm{L}$ da suspensão de proteínas solubilizadas. Valores de leitura da densidade ótica foram usados para estimar teor de proteínas em $\mathrm{mg} \mathrm{g}^{-1}$ de peso seco.

Os dados obtidos foram primeiramente submetidos à análise de variância individual e posteriormente à análise de variância conjunta com delineamento experimental de blocos casualizados. As médias dos caracteres foram agrupadas por meio do teste aglomerativo de SCOTT \& KNOTT (1974), a 5\% de probabilidade de erro. Todas as análises estatísticas foram realizadas com o auxílio do programa estatístico Genes (CRUZ, 2001). 


\subsection{RESULTADOS E DISCUSSÃO}

Os resultados das análises de variância individuais evidenciaram a existência de diferenças significativas a $5 \%$ de probabilidade de erro entre os clones para os caracteres quantitativos altura da primeira ramificação, altura da planta, peso da parte aérea sem a cepa, porcentagem de amido nas raízes, produtividade de raízes, nas duas safras e tempo para a cocção em minutos somente na safra 2 (Tabela 1 e 2), e os caracteres bioquímicos teor de carotenóides totais nas raízes e teor de proteínas nas raízes (Tabela 2), revelando a existência de variabilidade para o desempenho agronômico e características bioquímicas. Resultados semelhantes apresentaram a existência de ampla variação de desempenho agronômico entre acessos de mandioca de mesa na área do Cerrado (VIEIRA et al., 2009; SILVA et al., 2014).

Os coeficientes de variação variaram de $1,98 \%$ para o caráter tempo para a cocção a 12,31\% para o caractere produtividade de raízes na mesma safra 2011/2012, o que dá um indicativo da elevada precisão dos dados e controle dos efeitos ambientais dos experimentos (Tabelas 1 e 2).

Tabela 1. Resumo da análise de variância individual e coeficiente de variação (CV\%) dos caracteres altura da primeira ramificação em metro (APR), altura da planta em metro (AP), peso da parte aérea sem a cepa em $\mathrm{Kg} \mathrm{ha}^{-1}$ (PPA), e porcentagem de amido nas raízes (AM) avaliados em nove genótipos de mandioca de mesa, nas safras 2010/2011 (S1) e 2011/2012 (S2). UnB/ Embrapa Cerrados, Brasília, DF, 2015.

\begin{tabular}{|c|c|c|c|c|c|c|c|c|c|}
\hline \multirow{3}{*}{$\mathrm{FV}$} & \multirow{3}{*}{ GL } & \multicolumn{8}{|c|}{$\mathrm{QM}$} \\
\hline & & \multicolumn{2}{|c|}{ APR } & \multicolumn{2}{|c|}{ AP } & \multicolumn{2}{|c|}{ PPA } & \multicolumn{2}{|c|}{$\mathrm{AM}$} \\
\hline & & S1 & $\mathrm{S} 2$ & S1 & S2 & S1 & S2 & S1 & $\mathrm{S} 2$ \\
\hline Genótipos (G) & 8 & $0,26^{*}$ & $0,042^{*}$ & $0,15^{*}$ & $0,048^{*}$ & $48288543^{*}$ & $98014251^{*}$ & $8,30^{*}$ & $10,48^{*}$ \\
\hline Resíduo (R) & 16 & 0,001 & 0,002 & 0,013 & 0,004 & 3210099 & 7318347 & 0,85 & 0,65 \\
\hline Relação $\mathrm{QM}_{(\mathrm{R})}$ & & \multicolumn{2}{|c|}{2,00} & \multicolumn{2}{|c|}{3,25} & \multicolumn{2}{|c|}{2,28} & \multicolumn{2}{|c|}{1,31} \\
\hline $\mathrm{CV}(\%)$ & & 7,90 & 9,38 & 6,9 & 3,65 & 8,58 & 9,50 & 3,66 & 3,04 \\
\hline
\end{tabular}


Tabela 2. Resumo da análise de variância individual e coeficiente de variação (CV\%) dos caracteres produtividade de raízes em $\mathrm{Kg} \mathrm{ha}^{-1}$ (PR), tempo para a cocção em minutos (TC), teor de carotenoides totais nas raízes em $\mu \mathrm{g} \mathrm{g}^{-1}$ de massa seca (CT) e teor de proteínas nas raízes em $\mu \mathrm{g} \mathrm{g}^{-1}$ de massa seca (PT) avaliados em nove genótipos de mandioca de mesa, nas safras 2010/2011 (S1) e 2011/2012 (S2). UnB/ Embrapa Cerrados, Brasília, DF, 2015.

\begin{tabular}{|c|c|c|c|c|c|c|c|c|c|}
\hline \multirow{3}{*}{ FV } & \multirow{3}{*}{ GL } & \multicolumn{8}{|c|}{ QM } \\
\hline & & \multicolumn{2}{|c|}{ PR } & \multicolumn{2}{|r|}{$\mathrm{TC}$} & \multicolumn{2}{|c|}{$\mathrm{CT}$} & \multicolumn{2}{|c|}{$\mathrm{PT}$} \\
\hline & & S1 & S2 & S1 & $\mathrm{S} 2$ & S1 & $\mathrm{S} 2$ & S1 & $\mathrm{S} 2$ \\
\hline Genótipos (G) & 8 & 57833969 & $81646440^{*}$ & - & $20,90^{*}$ & $232^{*}$ & $417^{*}$ & $0,12^{*}$ & $0,22^{*}$ \\
\hline Resíduo (R) & 16 & 1706231 & 6920224 & - & 0,29 & 1,02 & 0,84 & 0,006 & 0,012 \\
\hline Relação $\mathrm{QM}_{(\mathrm{R})}$ & & \multicolumn{2}{|c|}{4,06} & & - & \multicolumn{2}{|c|}{1,21} & \multicolumn{2}{|c|}{2,00} \\
\hline CV (\%) & & 9,53 & 12,31 & - & 1,98 & 4,58 & 3,57 & 4,57 & 6,62 \\
\hline
\end{tabular}

A análise de variância conjunta apontou a existência de diferenças significativas a 5\% de probabilidade de erro entre as médias das safras para os caracteres: peso da parte aérea sem a cepa, produtividade de raízes e teor de carotenoides totais nas raízes (Tabelas 3), indicando que a média desses caracteres foi influenciada pelo fator safra. E a existência de interação significativa a 5\% de probabilidade de erro entre genótipos $\mathrm{x}$ safras para todos os caracteres aferidos (Tabelas 3), o que indica a presença de variação individual quanto ao fator safra no grupo de genótipos avaliados. Essa interação significa evidencia a necessidade da avaliação dos clones por mais de um ano, para a obtenção de uma estimativa segura da expressão final desses caracteres aferidos, corroborando o que foi relatado para mandioca por BORGES et al. (2002) e VIDIGAL FILHO et al. (2000). Também foi detectada a presença de interação significativa a 5\% de probabilidade de erro entre as médias dos genótipos para todos os caracteres (Tabelas 3), o que indica a presença de variação individual quanto ao fator safra no grupo de genótipos avaliados. 
Tabela 3. Resumo da análise de variância conjunta, média, coeficiente de variação $(\mathrm{CV} \%)$ e coeficiente de determinação genotípica (b) dos caracteres altura da primeira ramificação em metro (APR), altura da planta em metro (AP), peso da parte aérea sem a cepa em $\mathrm{Kg} \mathrm{ha}^{-1}$ (PPA), e porcentagem de amido nas raízes (AM), produtividade de raízes em $\mathrm{Kg} \mathrm{ha}^{-1}(\mathrm{PR})$, teor de carotenóides totais nas raízes em $\mu \mathrm{g} \mathrm{g} \mathrm{g}^{-1}$ de massa seca (CT) e teor de proteínas nas raízes em $\mu \mathrm{g} \mathrm{g}^{-1}$ de massa seca (PT) avaliados em nove genótipos de mandioca de mesa, nas safras 2010/2011 (S1) e 2011/2012 (S2). UnB/ Embrapa Cerrados, Brasília, DF, 2015.

\begin{tabular}{|c|c|c|c|c|c|c|c|c|}
\hline \multirow{2}{*}{$\mathrm{FV}$} & \multirow{2}{*}{ GL } & \multicolumn{7}{|c|}{ QM } \\
\hline & & APR & $\mathrm{AP}$ & PPA & AM & PR & $\mathrm{CT}$ & PT \\
\hline Blocos/Safra (B/S) & 4 & 0,001 & 0,05 & 3908618 & 2,84 & 2061652 & 1,02 & 0,015 \\
\hline Genótipos $(\mathrm{G})$ & 8 & $0,36^{*}$ & $0,11^{*}$ & $103271180^{*}$ & $14,24^{*}$ & $125881865^{*}$ & $591^{*}$ & $0,23^{*}$ \\
\hline Safras (S) & 1 & 0,001 & 0,17 & $779212896^{*}$ & 21,55 & $793477000^{*}$ & $181^{*}$ & 0,004 \\
\hline $\mathrm{G} \times \mathrm{S}$ & 8 & $0,032^{*}$ & $0,93^{*}$ & $43031613^{*}$ & $4,54^{*}$ & $13598544^{*}$ & $57^{*}$ & $0,113^{*}$ \\
\hline Resíduo (R) & 32 & 0,001 & 0,009 & 5264223 & 0,75 & 4313228 & 0,93 & 0,009 \\
\hline Total & 53 & - & - & - & - & - & - & - \\
\hline Média & & 0,42 & 1,75 & 24677 & 25,84 & 17543 & 23,90 & 1,68 \\
\hline $\mathrm{CV}(\%)$ & & 8,68 & 5,42 & 9,30 & 3,35 & 11,84 & 4,04 & 5,68 \\
\hline
\end{tabular}

*significativo a $5 \%$ de probabilidade de erro pelo teste $\mathrm{F}$.

No grupo de clones avaliados, os que apresentaram maiores médias para os caracteres altura da primeira ramificação (APR) e altura da planta (AP), características essas importantes para a seleção de variedades em função de estarem relacionados com a arquitetura da planta, foram respectivamente na safra 2010/2011 foi o clone 390/08 $(0,55 \mathrm{~m})$ e a testemunha IAC $576-70(0,58 \mathrm{~m})$ e na safra $2011 / 2012$ o clone $345 / 08$ (0,62 m), já altura da planta na safra 2010/2011 o clone 390/08 e na safra 2011/2012 os clones 345/08 e 378/08 (Tabela 4). Esses caracteres são importantes na seleção de genótipos por estarem relacionados à facilidade de tratos culturais, disponibilidade de manivas-sementes, facilidade de plantio mecanizado e colheita, sendo preferidos os clones que apresentam maior altura da primeira ramificação (VIEIRA et al., 2013), não podendo a altura ser excessiva (superior a $3 \mathrm{~m}$ ), que pode proporcionar acamamento de plantas em áreas com solos férteis e sujeitas a ventos fortes, sendo relatado por OTSUBO et al. (2008). Resultado este que não foi detectado no presente trabalho onde a maior altura de planta aferida foi de 2,23 m para o clone 390/08 na safra 2010/2011.

Quanto ao caráter peso da parte aérea (PPA) na safra de 2010/2011 o clone que apresentou média superior aos demais foi 390/08 (27493 $\mathrm{Kg} \mathrm{ha}^{-1}$ ). Na safra 2011/2012 foram os clones 406/08 (34406 Kg ha-1), 390/08 (33445 $\mathrm{Kg} \mathrm{ha}^{-1}$ ), 378/08 (32837 Kg ha- 
${ }^{1}$ ) e 341/08 (31944 Kg ha ${ }^{-1}$ ) (Tabela 4). Essa característica é importante no momento da seleção de clones por estar relacionado à possibilidade da utilização da parte aérea da mandioca como fonte de proteína na alimentação animal (SOUZA et al., 2011) e cobertura do solo (controle da erosão, manutenção de umidade no solo e controle de ervas daninhas).

Quanto à porcentagem de amido nas raízes na safra 2010/2011 os clones que apresentaram média superior aos demais foram os clones 378/08 (27,33 \%), 413/08 $(26,88 \%)$ e a testemunha IAC 576-70 (26,61\%). Na safra 2011/2012 foram os clones 413/08 (28,48\%), 390/08 (28,30\%) e a testemunha IAC 576-70 $(29,35)$ (Tabela 4). Essa característica, apesar de ser mais importante na seleção de materiais para a indústria de farinha e fécula, em função de juntamente com a produtividade de raízes determinarem o potencial produtivo de determinado acesso, tem importância na seleção de clones de mandioca de mesa quando se pensa no aproveitamento das raízes para duplo-propósito (mesa e indústria).

Tabela 4. Médias dos caracteres dos caracteres altura da primeira ramificação em metro (APR), altura da planta em metro (AP), peso da parte aérea sem a cepa em $\mathrm{Kg} \mathrm{ha}^{-1}$ (PPA) e porcentagem de amido nas raízes (AM), avaliados em nove genótipos de mandioca de mesa, nas safras 2010/2011 (S1) e 2011/2012 (S2). UnB/ Embrapa Cerrados, Brasília, DF, 2015.

\begin{tabular}{|c|c|c|c|c|c|c|c|c|}
\hline Genótipos & $\begin{array}{c}\text { APR } \\
\text { S1 }\end{array}$ & $\begin{array}{c}\text { APR } \\
\text { S2 }\end{array}$ & $\begin{array}{l}\text { AP } \\
\text { S1 }\end{array}$ & $\begin{array}{l}\text { AP } \\
\text { S2 }\end{array}$ & $\begin{array}{c}\text { PPA } \\
\text { S1 }\end{array}$ & $\begin{array}{c}\text { PPA } \\
\text { S2 }\end{array}$ & $\begin{array}{c}\mathrm{AM} \\
\text { S1 }\end{array}$ & $\begin{array}{l}\text { AM } \\
\text { S12 }\end{array}$ \\
\hline Clone 341 & $0,32 \mathrm{Ac}^{*}$ & $0,22 \mathrm{Be}$ & $1,67 \mathrm{Ac}$ & $1,70 \mathrm{Ab}$ & $22863 \mathrm{Bb}$ & $31944 \mathrm{Aa}$ & $25,50 \mathrm{Ab}$ & $23,65 \mathrm{Bc}$ \\
\hline Clone 345 & $0,32 \mathrm{Bc}$ & $0,62 \mathrm{Aa}$ & $1,57 \mathrm{Bc}$ & $1,90 \mathrm{Aa}$ & $12766 \mathrm{Bd}$ & $22323 \mathrm{Ac}$ & $25,23 \mathrm{Ab}$ & $25,44 \mathrm{Ab}$ \\
\hline Clone 378 & $0,42 \mathrm{Bb}$ & $0,55 \mathrm{Ab}$ & $1,57 \mathrm{Bc}$ & $2,03 \mathrm{Aa}$ & $19563 \mathrm{Bc}$ & 32837 Аа & $27,33 \mathrm{Aa}$ & $26,29 \mathrm{Ab}$ \\
\hline Clone 387 & $0,42 \mathrm{Ab}$ & $0,37 \mathrm{Ad}$ & $1,67 \mathrm{Ac}$ & $1,60 \mathrm{Ab}$ & $18993 \mathrm{Bc}$ & $27161 \mathrm{Ab}$ & $22,93 \mathrm{Bc}$ & $24,82 \mathrm{Ac}$ \\
\hline Clone 390 & $0,55 \mathrm{Aa}$ & $0,50 \mathrm{Ac}$ & $2,23 \mathrm{Aa}$ & $1,90 \mathrm{Ba}$ & $27493 \mathrm{Ba}$ & $33445 \mathrm{Aa}$ & $25,78 \mathrm{Bb}$ & $28,30 \mathrm{Aa}$ \\
\hline Clone 395 & $0,37 \mathrm{Ac}$ & $0,38 \mathrm{Ad}$ & $1,60 \mathrm{Ac}$ & $1,75 \mathrm{Ab}$ & $23823 \mathrm{Bb}$ & $28432 \mathrm{Ab}$ & $23,28 \mathrm{Bc}$ & $26,03 \mathrm{Ab}$ \\
\hline Clone 406 & $0,40 \mathrm{Bb}$ & $0,47 \mathrm{Ac}$ & $1,50 \mathrm{Bc}$ & $1,80 \mathrm{Ab}$ & $21035 \mathrm{Bc}$ & $34406 \mathrm{Aa}$ & $23,33 \mathrm{Bc}$ & $25,88 \mathrm{Ab}$ \\
\hline Clone 413 & $0,43 \mathrm{Ab}$ & $0,38 \mathrm{Ad}$ & $1,58 \mathrm{Bc}$ & $1,80 \mathrm{Ab}$ & $19910 \mathrm{Bc}$ & $28698 \mathrm{Ab}$ & $26,88 \mathrm{Ba}$ & $28,48 \mathrm{Aa}$ \\
\hline BGMC 753 & $0,58 \mathrm{Aa}$ & $0,38 \mathrm{Bd}$ & $1,83 \mathrm{Ab}$ & $1,75 \mathrm{Ab}$ & $21462 \mathrm{Ac}$ & $17038 \mathrm{Bd}$ & $26,61 \mathrm{Ba}$ & $29,35 \mathrm{Aa}$ \\
\hline Média & $0,42 \mathrm{~A}$ & $0,43 \mathrm{~A}$ & $1,69 \mathrm{~A}$ & $1,80 \mathrm{~A}$ & 20879 B & $28476 \mathrm{~A}$ & $25,21 \mathrm{~A}$ & $26,47 \mathrm{~A}$ \\
\hline Amplitude & 0,27 & 0,40 & 0,73 & 0,43 & 14727 & 17368 & 4,40 & 5,69 \\
\hline
\end{tabular}

Com base no teste de agrupamento de médias, verificou-se que a testemunha IAC 576-70 teve média superior aos demais para o caráter produtividade de raízes (PR) 
em ambas as safras, resultado este que era esperado por se tratar de uma cultivar comercial, adaptada a região do Cerrado e que possui coloração da polpa creme. Para esse caráter foram identificados clones com boas médias respectivamente abaixo da testemunha, na safra 2010/2011 o clone 341/08 (17235 Kg ha $\left.{ }^{-1}\right)$. Na safra 2011/2012 os clones 406/08 (24764 Kg ha $\left.{ }^{-1}\right), 390 / 08$ (23104 Kg ha $\left.{ }^{-1}\right), 387 / 08$ (21071 Kg ha-1) e 341/08 (20674 $\mathrm{Kg} \mathrm{ha}^{-1}$ ) (Tabela 5).

O caractere tempo para a cocção não foi considerado na análise de variância da safra 2010/2011 uma vez que nenhum genótipo incluindo a variedade recomendada para o cultivo na região do Distrito Federal e entorno utilizada como testemunha (IAC 57670) apresentou tempo inferior a 30 minutos, devido a problemas climáticos e ao percevejo de renda que ocorreram durante essa safra agrícola, na safra 2011/2012 todos os clones apresentaram tempo para a cocção inferior a 30 minutos, destacando-se o genótipo que apresentou média e inferior aos demais que foi a testemunha IAC 576-70 (Tabela 5). A análise conjunta desses dois caracteres é fundamental para a seleção de clones de mandioca de mesa, uma vez que determina o potencial produtivo dos clones e a qualidade culinária das raízes produzidas no local de condução do experimento (FUKUDA et al., 2002; CEBALLOS et al., 2004).

Quanto ao teor de carotenóides, todos os clones apresentaram teor de carotenoides muito superior ao da testemunha (Tabela 5), dentre os clones avaliados apenas o clone 406/08 apresentou média superiores aos demais para o caráter teor de carotenóides totais nas raízes na safra 2010/2011 com 39,19 $\mu \mathrm{g} \mathrm{g}{ }^{-1}$ e na safra 2011/2012 o clone 341/08 com 42,80 $\mu \mathrm{g} \mathrm{g}^{-1}$ (Tabela 5). Em trabalho relatado por SILVA et al. (2014) após analisar 13 acessos de mandioca do Banco Regional de Germoplasma de Mandioca do Cerrado (BGMC), em que a presença dos teores de carotenóides em raízes de reserva de mandioca de coloração rosada apresentaram maiores médias em relação com coloração da polpa creme ou amarela, provavelmente seja decorrente do fato de acumularem licopeno e $\beta$-caroteno em suas raízes de reserva (CARVALHO et al., 2012). Segundo SHAMI \& MOREIRA (2004) as maiores fontes de licopeno são encontradas nos tomates e derivados, o tomate cru apresenta em média $30 \mathrm{mg}$ de licopeno/Kg do fruto, suco de tomate cerca de $150 \mathrm{mg}$ de licopeno/litro, e o catchup contém em média $100 \mathrm{mg} / \mathrm{Kg}$.

Para o caractere teor de proteínas nas raízes (PT) na safra 2010/2011 o clone que apresentou média superior aos demais foi o clone 406/08 com 2,00 $\mu \mathrm{g} \mathrm{g}^{-1}$ de massa seca. Na safra 2011/2012 foi à variedade testemunha IAC 576-70 com 2,21 $\mu \mathrm{g} \mathrm{g}^{-1} \mathrm{de}$ 
massa seca (Tabela 5). Em trabalho realizado por CARVALHO et al. (2013) após analisar de 29 espécies nativas de mandioca, conservadas no Banco de Germoplasma da Embrapa Recursos Genéticos e Biotecnologia, analisando quanto ao teor de proteínas e carotenóides. Foi observado que conforme variaram os teores de proteínas os teores de carotenóides também tiveram a mesma variação, fato este que não foi observado nos clones analisados no presente trabalho. Entretanto, ainda existem poucos relatos na literatura de estudos visando o teor de proteínas encontradas em raízes de reserva de mandioca, com vista à utilização no melhoramento genético.

Quanto ao teor de ácido cianídrico $(\mathrm{HCN})$ nas raízes de reserva de mandioca em todos os clones revelaram quantidades inferiores a $100 \mathrm{mg} \mathrm{Kg}^{-1}$ (Tabela 5), portanto sendo próprios para a comercialização como vegetal fresco in natura. SILVA et al. (2014) após analisar 13 acessos de mandioca do Banco Regional de Germoplasma de Mandioca do Cerrado (BGMC), em que as médias de cinco acessos revelaram teores de ácido cianídrico nas raízes superiores a $100 \mathrm{mg} \mathrm{Kg}^{-1}$, podendo ser utilizado esses acessos como genitores no melhoramento genético, sendo possível a seleção de clones com baixos teores ácido cianídrico nas raízes de reserva, mesmo em progênies oriundas de acessos com elevados teores de ácido cianídrico nas raízes (VALLE et al., 2004).

Tabela 5. Comparação de médias dos caracteres dos caracteres produtividade de raízes em Kg ha ${ }^{-1}(\mathrm{PR})$, tempo para a cocção em minutos (TC), teor de carotenóides totais nas raízes em $\mu \mathrm{g} \mathrm{g}^{-1}$ de massa seca (CT), teor de proteínas nas raízes em $\mu \mathrm{g} \mathrm{g}^{-1}$ de massa seca $(\mathrm{PT})$ e o teor de ácido cianídrico nas raízes em $\mathrm{mg} \mathrm{Kg}^{-1}(\mathrm{HCN})$, avaliados em nove genótipos de mandioca de mesa, nas safras 2010/2011 (S1) e 2011/2012 (S2). UnB/ Embrapa Cerrados, Brasília, DF, 2015.

\begin{tabular}{|c|c|c|c|c|c|c|c|c|}
\hline \multirow{2}{*}{ Acessos } & PR & PR & $\mathrm{TC}$ & CT & CT & PT & PT & $\mathrm{HCN}$ \\
\hline & S1 & S2 & S2 & S1 & S2 & $\mathrm{S} 2$ & S2 & S1 \\
\hline Clone 341 & $17235 \mathrm{Ab}^{*}$ & $20674 \mathrm{Ab}$ & $25.67 \mathrm{c}$ & $27,93 \mathrm{Bb}$ & $42,80 \mathrm{Aa}$ & $1,79 \mathrm{Ab}$ & $1,39 \mathrm{Bd}$ & $25-40$ \\
\hline Clone 345 & $7655 \mathrm{Bd}$ & $17229 \mathrm{Ac}$ & $29,33 \mathrm{a}$ & $19,92 \mathrm{Be}$ & $31,33 \mathrm{Ac}$ & $1,61 \mathrm{Ac}$ & $1,43 \mathrm{Bd}$ & $40-60$ \\
\hline Clone 378 & $11451 \mathrm{Bc}$ & $15389 \mathrm{Ac}$ & $27,00 \mathrm{~b}$ & $21,57 \mathrm{Bd}$ & $27,66 \mathrm{Ad}$ & $1,73 \mathrm{Ab}$ & $1,38 \mathrm{Bd}$ & $40-60$ \\
\hline Clone 387 & $11820 \mathrm{Bc}$ & $21071 \mathrm{Ab}$ & $25,33 \mathrm{c}$ & $22,33 \mathrm{Ad}$ & $20,94 \mathrm{Af}$ & $1,57 \mathrm{Ac}$ & $1,63 \mathrm{Ac}$ & $40-60$ \\
\hline Clone 390 & $12896 \mathrm{Bc}$ & $23104 \mathrm{Ab}$ & $29,33 \mathrm{a}$ & $23,76 \mathrm{Ac}$ & $20,55 \mathrm{Bf}$ & $1,84 \mathrm{Ab}$ & $1,84 \mathrm{Ab}$ & $40-60$ \\
\hline Clone 395 & $11387 \mathrm{Bc}$ & $19417 \mathrm{Ac}$ & $30,00 \mathrm{a}$ & $18,65 \mathrm{Be}$ & $23,05 \mathrm{Ae}$ & $1,34 \mathrm{Bd}$ & $1,57 \mathrm{Ac}$ & $25-40$ \\
\hline Clone 406 & $13889 \mathrm{Bc}$ & $24764 \mathrm{Ab}$ & $26,67 \mathrm{~b}$ & $39,19 \mathrm{Ba}$ & $41,06 \mathrm{Ab}$ & $2,00 \mathrm{Aa}$ & $1,83 \mathrm{Bb}$ & $25-40$ \\
\hline Clone 413 & $13844 \mathrm{Bc}$ & $17826 \mathrm{Ac}$ & $28,67 \mathrm{a}$ & $19,40 \mathrm{Ae}$ & $19,82 \mathrm{Af}$ & $1,51 \mathrm{Bc}$ & $1,79 \mathrm{Ab}$ & $60-85$ \\
\hline IAC 576-70 & $23215 \mathrm{Ba}$ & $32917 \mathrm{Aa}$ & $21,67 \mathrm{~d}$ & 5,80 Af & $4,34 \mathrm{Ag}$ & $1,85 \mathrm{Bb}$ & $2,21 \mathrm{Aa}$ & $25-40$ \\
\hline Média & $13710 \mathrm{~B}$ & $21377 \mathrm{~A}$ & 27,07 & $22,06 \mathrm{~B}$ & $25,73 \mathrm{~A}$ & $1,52 \mathrm{~A}$ & $1,48 \mathrm{~A}$ & \\
\hline Amplitude $^{\#}$ & 15561 & 17528 & 8,33 & 33,39 & 38,46 & 0,66 & 0,83 & \\
\hline
\end{tabular}


Com base nos resultados obtidos, é possível afirmar que, no grupo dos clones avaliados, alguns apresentam destaque do desempenho agronômico e bioquímico que permitem o seu cultivo de forma comercial na região do Cerrado do Brasil. Nesse sentido, destacam-se como possíveis clones para o plantio comercial da cultura, aqueles com elevado teor de carotenóides aliado a boa produtividade como 390/08, 341/08 e 406/08. Dentre os clones avaliados, existem aqueles com grande potencial para utilização como genitores no melhoramento da cultura em cruzamentos com constituições genéticas adaptadas as condições do Cerrado do Brasil, visando o sistema de produção de mandioca de mesa biofortificada sejam viabilizadas na região.

\subsection{CONCLUSÕES}

Entre os clones avaliados, alguns tiveram destaque no desempenho agronômico com base nos caracteres altura da primeira ramificação (390/08, 345/08 e a testemunha IAC 576-70), altura da planta (390/08, 345/08 e 378/08), peso da parte aérea sem a cepa (390/08, 406/08, 390/08, 378/08 e 341/08), porcentagem de amido nas raízes (378/08, 413/08, 390/08 e a testemunha IAC 576-70), produtividade de raízes (testemunha IAC 576-70, 341/08, 406/08, 390/08 e 387/08). Com relação ao tempo de cocção na safra 2011/2012, todos os clones tiveram tempo de cozimento inferior a 30 minutos.

Com relação o teor de carotenóides totais nas raízes, os clones que se destacaram foram 406/08 e 341/08 e com relação ao teor de proteínas nas raízes, os clones 406/08 e a testemunha IAC 576-70. Quanto aos teores de $\mathrm{HCN}$ nas raízes de reserva de mandioca, todos tiveram menos de $100 \mathrm{mg} \mathrm{Kg}^{-1} \mathrm{em}$ todos os clones avaliados.

Foi possível identificar clones elite com potencial agronômico e bioquímico para cultivo direto pelos produtores na região do Cerrado do Brasil Central e/ou para a utilização como genitores em programas de melhoramento genético de mandioca de mesa. 


\subsection{REFERÊNCIAS BIBLIOGRÁFICAS}

BORGES, M. F.; FUKUDA, W. M. G.; ROSSETTI, A. G. Avaliação de variedades de mandioca para consumo humano. Pesquisa Agropecuária Brasileira, v.37, p.1559$1565,2002$.

CARVALHO, L.M.J.; OLIVEIRA, A. R. G.; GODOY, R. L. O.; PACHECO, S.; NUTTI, M. R.; CARVALHO, J. L. V. de; PEREIRA, E. J.; FUKUDA, W. G. Retention of total carotenoid and $\beta$-carotene in yellow sweet cassava (Manihot esculenta Crantz) after domestic cooking. Food \& Nutrition Research, v.56, 15788, 2012. Disponível em: Acesso em: 2 dezembro. 2013. doi: 10.3402/fnr.v56i0.15788.

CARVALHO L. J. C. B.; ALMEIDA, J. D.; ANDERSON, J. V. ; VIEIRA, E. A.; CHEN, S.; SOUZA, C. R. B. ; FUHRMANN, E. ; SILVA, J. P. Studies on Variation of Carotenoid-Proteins Content in Cassava (Manihot esculenta Crantz) Storage Root Reveal Implications for Breeding and the Use of Induced Mutations. Mutation Breeding Newsletter, v. 3, p. 25-36, 2013.

CEBALlOS, H.; IGLESIAS, C. A.; PÉREZ, J. C.; DIXON, A. G. O. Cassava breeding: opportunities and challenges. Plant Molecular Biology, Dordrecht, v. 56, p. 503-516, 2004.

CRUZ, C. D. Programa genes: aplicativo computacional em genética e estatística. Viçosa: UFV, 2001. 648p.

FIALHO, J. F.; SOUSA, D. M. G.; VIEIRA, E.A. Manejo do solo no cultivo de mandioca. In: FIALHO, J. F.; VIEIRA, E.A. Mandioca no Cerrado: orientações técnicas. 2. ed. Planaltina: Embrapa Cerrados, p.39-60, 2013.

FIALHO, J.F.; VIEIRA, E.A. Manejo e tratos culturais da mandioca. In: FIALHO, J.F.; VIEIRA, E.A. (Ed.). Mandioca no Cerrado: orientações técnicas. 2. ed. Planaltina: Embrapa Cerrados, p.61-88, 2013.

FIALHO, J. F.; VIEIRA, E. A.; SILVA, M. S.; PAULA-MORAES, S. V. de; FUKUDA, W. M. G.; FIALHO, M. O. S. dos S.; SILVA, K. N. Desempenho de variedades de mandioca de mesa no Distrito Federal. Revista Brasileira de Agrociência, v. 15, n. 01-04, p. 31-35, 2009.

FUKUDA, W. M. G.; FUKUDA, C.; DIAS, M. C.; XAVIER, J. J. B. N.; FIALHO, J. F. Cultivares de Mandioca Recomendadas para o Brasil - 2002.Cruz das Almas, Bahia: Embrapa Mandioca e Fruticultura, 2002. 8p. (Embrapa-CNPMF, Circular Técnica, 49). 
LORENZI, J. O. \& DIAS, C. A. C. Cultura da mandioca. Campinas: CATI, 1993. $41 \mathrm{p}$.

OLSEN, K. M. SNPs, SSRs and inferences on cassava's origin. Plant Molecular

Biology, v.56, p.517-526, 2004. Disponível em: <http://www.springerlink.com/content/v1j742p484403748/ fulltext.pdf>. Acesso em: 11 jan. 2013. doi: 10.1007/s11103- 004-5043-9.

OTSUBO, A. A.; MERCANTE, F. M.; SILVA, R. F. da; BORGES, C. D. Sistemas de preparo do solo, plantas de cobertura e produtividade da cultura da mandioca. Pesquisa Agropecuária Brasileira, v. 43, n. 03, p. 327-332, 2008.

RODRIGUEZ-AMAYA, D.; KIMURA, M. H. Handbook for Carotenoid Analysis. Washington, DC and Cali: IFPRI and CIAT, 2004. 58p. (HarvestPlus Technical Monograph, 2).

SHAMI, N.J.I.E. \& MOREIRA, E.A.M. Licopeno como agente antioxidante. Revista de Nutrição. v. 17, n. 2, p. 227-236, 2004.

SCOTT, A. J.; KNOTT, M. A. A cluster analysis methods for grouping means in the analysis of variance. Biometrics, v.30, p.507-512, 1974.

SILVA, K. N. ; VIEIRA, E. A.; FIALHO, J. de F.; CARVALHO, L. J. C. B.; SILVA, M. S. Potencial agronômico e teor de carotenoides em raízes de reserva de mandioca. Ciência Rural (UFSM. Impresso), v. 44, p. 1348-1354, 2014.

SOUZA, A. S.; ROCHA JÚNIOR, V. R.; MOTA, A. D. S.; PALMA, M. N. N..; FRANCO, M. O.; DUTRA, E. S.; SANTOS, C. C. R.; AGUIAR, A. C. R.; OLIVEIRA, C. R. Valor nutricional de frações da parte aérea de quatro variedades de mandioca. Revista Brasileira de Saúde e Produção Animal, Salvador, v. 12, n. 2, p.441-455, 2011.

VALLE, T.L.; CARVALHO, C. R. L.; RAMOS, M. T. B.; MUHLEN, G. S.; VILLELA, O. V. Conteúdo cianogênico em progênies de mandioca originadas do cruzamento de variedades mansas e bravas. Bragantia, v.63, p.221-226, 2004. Disponível em: Acesso em: 13 novembro 2014. doi: 10.1590/S0006-87052004000200007.

VIDIGAL FILHO, P. S.; PEQUENO, M. G.; SCAPIM, C. A.; VIDIGAL, M. C. G.; MAIS, R. R.; SAGRILO, E.; SIMON, G. A.; LIMA, R. S. Avaliação de cultivares de mandioca na região noroeste do Paraná. Bragantia, v.59, n.1, p.69-75, 2000.

VIEIRA, E. A.; FIALHO, J. F.; SILVA, M.S. Recursos genéticos e melhoramento da mandioca In: In: FIALHO, J. F.; VIEIRA, E. A. (Eds.). Mandioca no Cerrado: orientações técnicas. Brasília-DF: Embrapa Cerrados, v.1, p. 25-35, 2011. 
VIEIRA, E. A.; FIALHO, J. F.; SILVA, M.S. Recursos genéticos e melhoramento da mandioca In: In: FIALHO, J. F.; VIEIRA, E. A. (Eds.). Mandioca no Cerrado: orientações técnicas. Planaltina: Embrapa Cerrados, v.2, p. 56-67, 2013.

VIEIRA, E.A.; FIALHO, J. F.; SILVA, M. S.; FUKUDA, W. M. G.; SANTOS FILHO, M.O.S. Comportamento de genótipos de mandioca de mesa no Distrito Federal. Ciência Agronômica, v.40, p.113-122, 2009.

ZANCUL M.S. Fortificação de alimentos com ferro e vitamina A. Medicina, Ribeirão Preto, v.37, p. 45-50, 2004.

WILLIAMS, H. J.; EDWARDS, T. G. Estimation cyanide with alkaline pricrate. Journal of the Science of Food Agriculture, Chichester, v. 31, p. 15-22, $1980 . \quad$ Disponível em: <http://onlinelibrary.wiley.com/doi/101002/jsfa.2740310104/abstract>. Acesso Acesso em: 12 janeiro de 2014. 


\section{CONSIDERAÇÕES FINAIS}

Os programas de melhoramento genético de mandioca necessitam avaliar os genótipos para serem lançados como futuras variedades, de forma eficiente e que tenha um baixo custo, desta forma, os descritores morfológicos, foram importantes neste trabalho. Os clones que foram avaliados se diferenciaram morfologicamente entre eles tanto com polpa amarelada como os de polpa rosada, podendo ser protegidas junto ao Ministério da Agricultura e serem lançadas como futuras variedades.

É necessário, portanto, continua as avaliações dos clones avaliados, às diversas doenças e pragas, já que em campo, ocorre infecção múltipla. Também é importante introduzir novos genótipos por meio de intercâmbio e obter outras gerações de híbridos por cruzamentos diretos ou indiretos das cultivares comerciais com outras espécies com maior quantidade de $\beta$-caroteno e licopeno, considerando-se também as características relativas à produtividade e qualidade culinárias para o consumo.

Quanto aos caracteres agronômicos e bioquímicos avaliados, verificou-se no presente trabalho a possibilidade de alguns clones serem lançados como futuras variedades com enfoque não somente na produtividade dos clones, mas também no aumento do $\beta$-caroteno nas mandiocas com polpa amarelada e o licopeno nas com polpa rosada. A partir dos caracteres bioquímicos foi possível identificar os clone 94/08 e 246/08 com polpa amarelada e os clones 341/08 e 406/08 com polpa rosada para um possível lançamento como nova variedade e/ou numa possível inserção em programas de melhoramento. Outro aspecto a ser considerado são as características agronômicas, já que estas são caracteres de importância para o plantio e a comercialização da mandioca no mercado. Tem-se obtido sucesso no uso das avaliações morfológica, agronômica e bioquímica na cultura da mandioca tanto em campo como em laboratório pelo seu custo baixo, resultado preciso e de fácil aplicação. 